NK

7999

N27

CHM

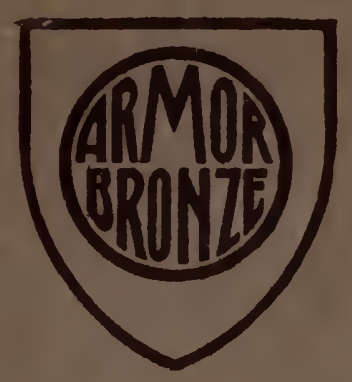

Artistic and ideal gifts in

\author{
BOOK ENDS \\ DOOR STOPS
}

ART OBJECTS

TABLE and FLOOR LAMPS

The NATIONAL METALIZING COMPANY 
The R. denter kite ty11922 


\title{
ARMOR BRONZE
}

\author{
A SEAMLESS ARMOR OF PURE BRONZE \\ CAST OVER AN EVERLASTING CORE
}

ARMOR BRONZE has attained a standard of excellence never before approached in any other metallic process except the finest grade of cast-bronze.

By this wonderful process it is now possible to procure fac-simile reproductions of the world's most notable sculpture and objects d'art at prices which place them within reach of the most moderate purse.

ARMOR BRONZE PRODUCTS include a magnificent assortment of subjects suitable for gifts for all occasions and for general decorative use in the home.

This catalogue illustrates a large variety of

\section{BOOK ENDS, DOOR STOPS}

\section{ART OBJECTS, TABLE and FLOOR LAMPS}

We manufacture an extensive range of Decorative Lighting Fixtures for residences and Buildings of all kinds.

Illustrations and prices of stock designs may be had on application.

Drawings and estimates on special designs are furnished without charge on receipt of plans or specifications.

Our latest production is a new finish, or rather an old process that we have revived. The ancient Egyptians and Chinese knew how to apply color to bronze by what is termed the "Polychrome" method.

We are merely doing what the ancients did in the way they did it. It is a process that produces colors that are soft in tone and harmonious in combination. The finish is permanent and beautiful.

On some of the articles thus finished the "Sgraffito" process has been used. This, too, is an old process, a method of etching by hand through the colors to allow the antique gold (which is the main color used for the ground) to shine through in a variety of delicate designs.

The color illustration on the opposite page gives only a vague suggestion of the unusual effects produced by Polychrome and Sgraffito. Other subjects which may be had, finished in this method, are listed on the following pages.

All of our designing and sculpture is under the general direction of Francis G. Plant, an artist of international experience, and associated with us are some of the most prominent American and European sculptors.

\section{The NATIONAL METALIZING COMPANY}

Show-rooms, Studio

and Sales Offices,
333 Fourth Avenue, (near 25th Street)

NEW YORK CITY

Catalogue D C. All previous catalogues cancelled. 


\section{A R M O R \\ B R O N Z E}

Price $\$ 5.00$ Pair

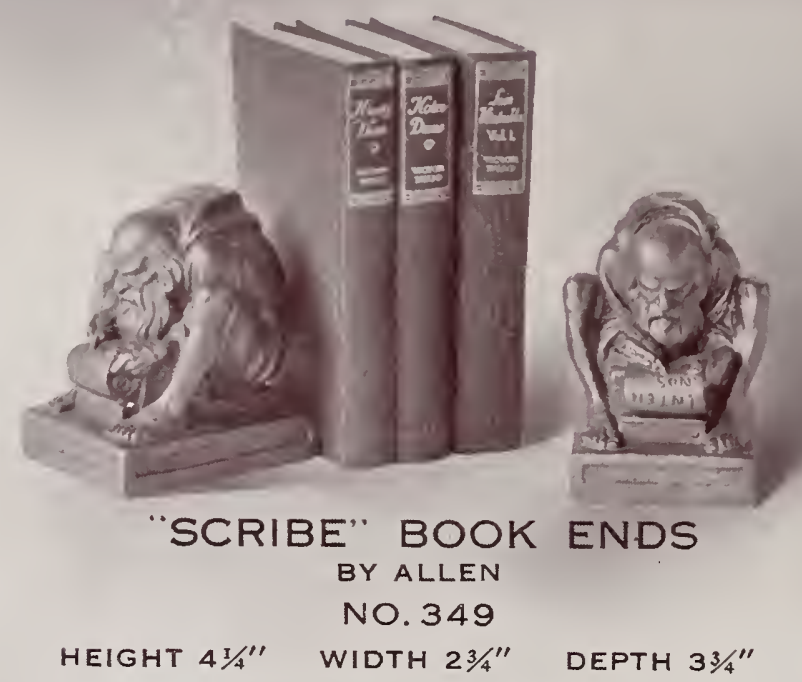

Price $\$ 7.00$ Pair
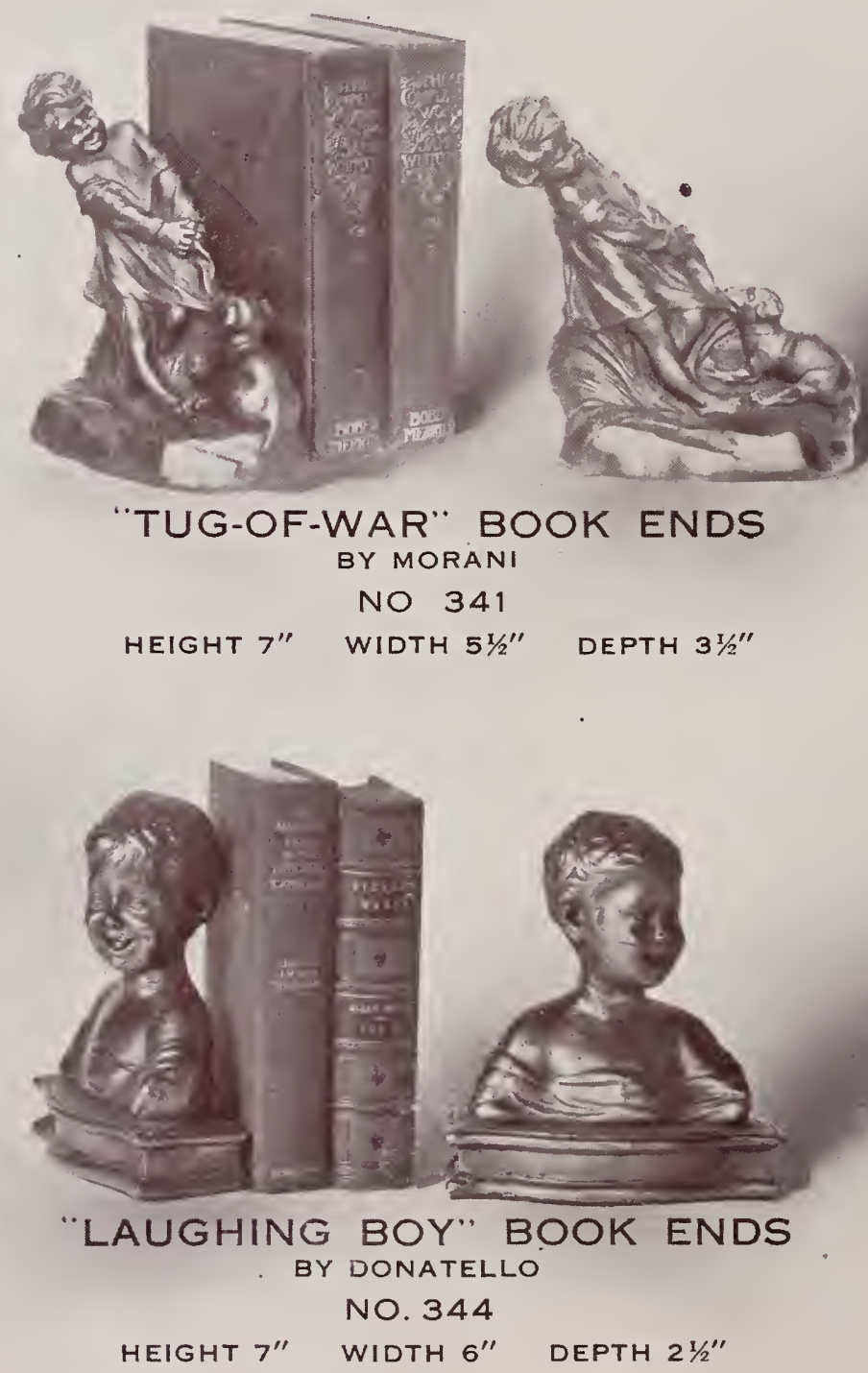

Price \$8.00 Pair

HEIGHT $7^{\prime \prime}$

WIDTH $6^{\prime \prime}$ 


\section{A R M O R B B B B B}

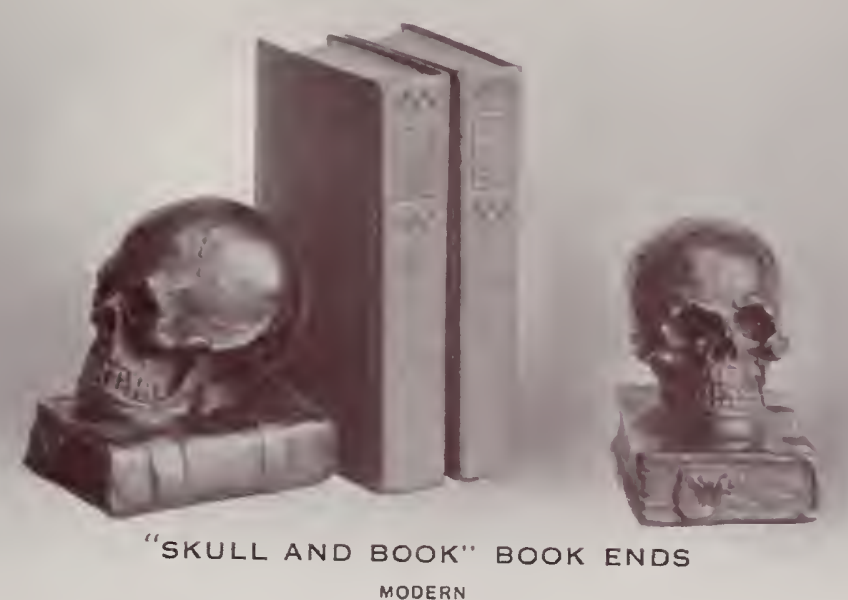

NO. 329

Price $\$ 5.00$ Pair

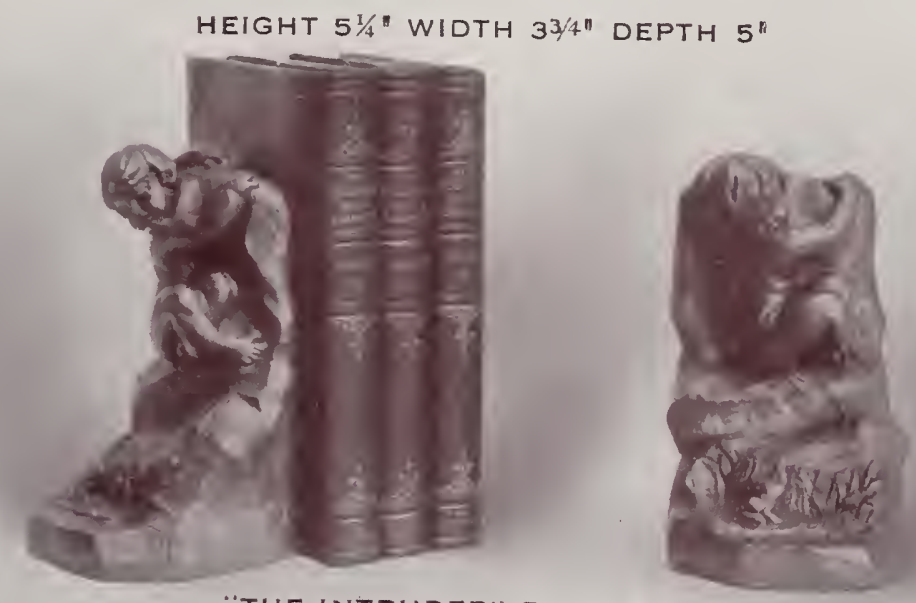

"THE INTRUDER" BOOK ENDS

BY MORANI

NO. 324

Price $\$ 7.00$ Pair

HEIGHT 71/2" WIDTH $4 \frac{1}{2}{ }^{n}$ DEPTH $4 \frac{1}{2}$ "
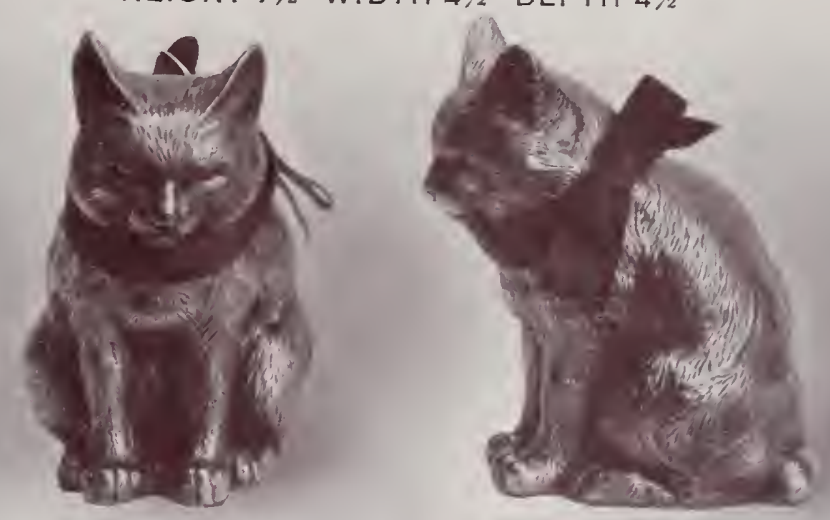

SLEEPY CAT" DOOR STOP

MODERN

NO. 201

Price in Black or

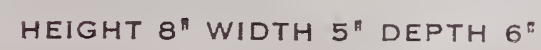

White $\$ 6.00$ Each 


\section{A R M O R}
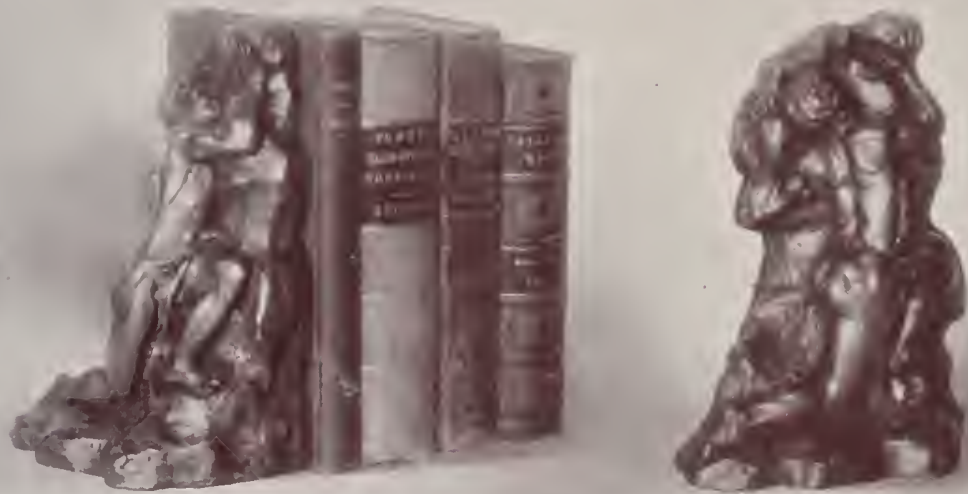

ATHLETE" BOOK ENDS

BY MELIODON

NO. 333

HEIGHT 8" WIDTH 6" DEPTH 4"
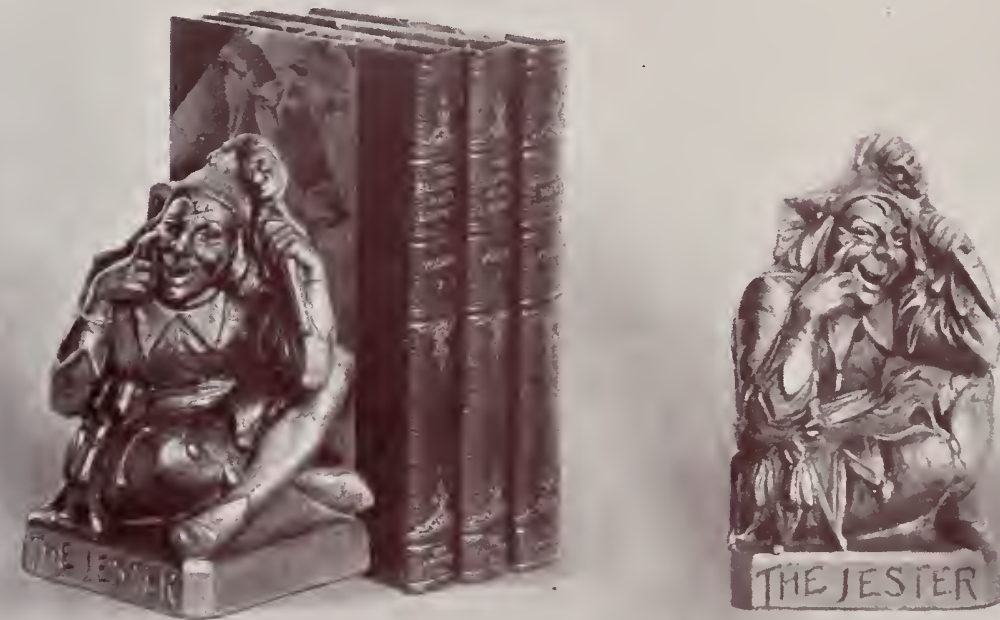

"THE JESTER" BOOK ENDS

BY RUHL

NO. 332

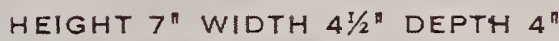

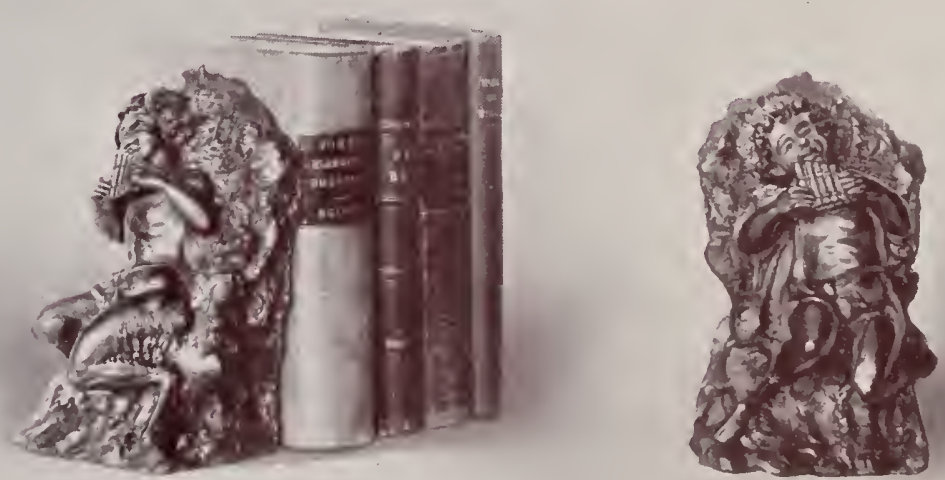

"WOOD IMP" BOOK ENDS

BY MELLODON

NO. 335

Price $\$ 7.00$ Pair

HEIGHT $7{ }^{1 / 2 n}$ WIDTH $4{ }^{1 / 2}$ " DEPTH $4^{\text {" }}$ 


\section{$\Lambda \mathrm{R} M \mathrm{OR}$}

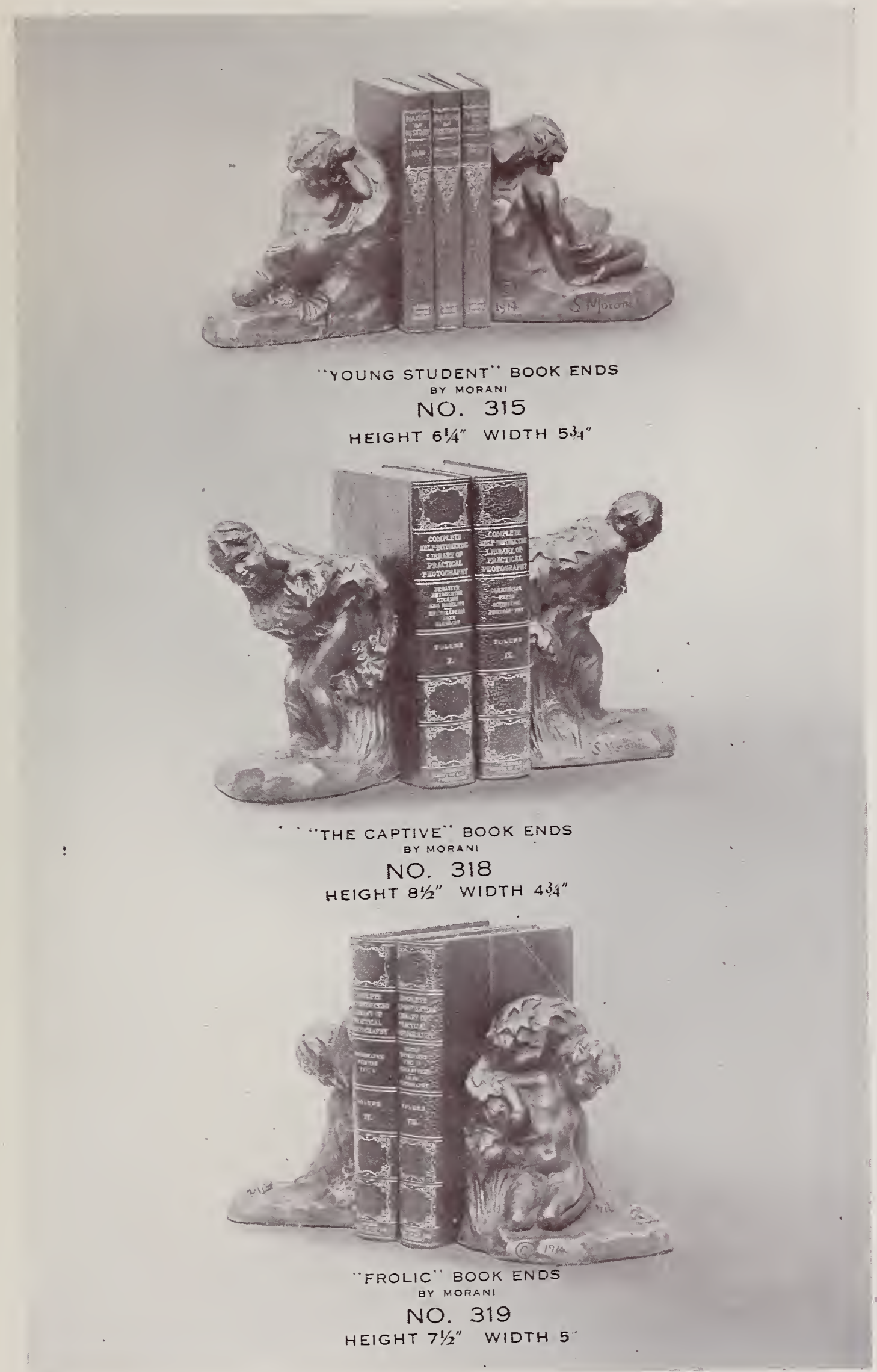

Price $\$ 7.03$ I ins

Price $\$ 7.00$ Pair 


\section{A R M O R \\ B R O N Z E

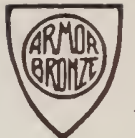

Price $\$ 6.00$ Pair

Price $\$ 7.00$ Pair

Price $\$ 7.00$ Pair

\section{Price $\$ 6.00$ Pais}

THE NATIONAL METALIZING COMPANY

Page Eight 


\section{A R M O R}

\section{B R O N Z E}

Price $\$ 6.00$ Pair
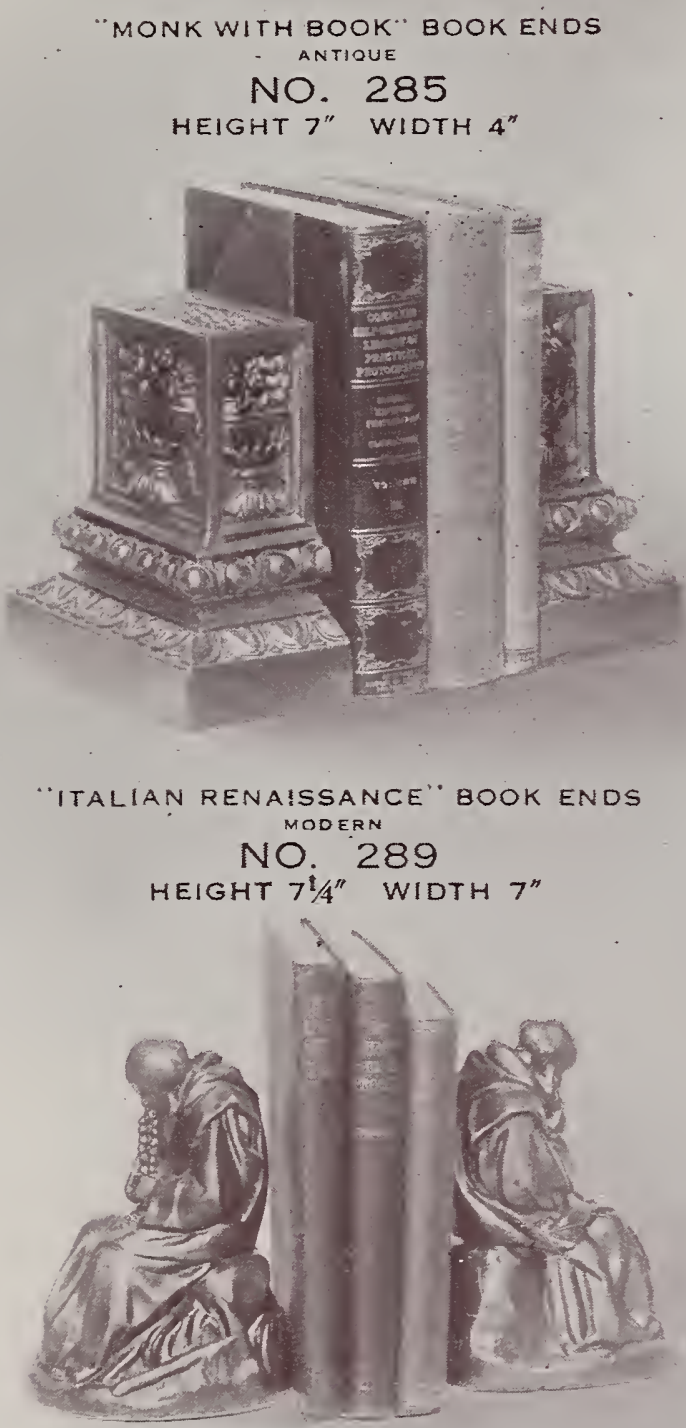

"MONK WITH ROSARY" BOOK ENDS

NO. 286

HEIGHT 7" WIDTH 4"

Price $\$ 7.00$ Pair

\section{Price in}

Polychrome

$\$ 10.00$ Pair 
Price $\$ 7.00$ Pair Price in

Polychrome and Sgraffito $\$ 10.00$ Pair

Price $\$ 8.00$ Pair Price $\$ 7.00$ Pair

\section{A R M O R \\ B R O N Z E}

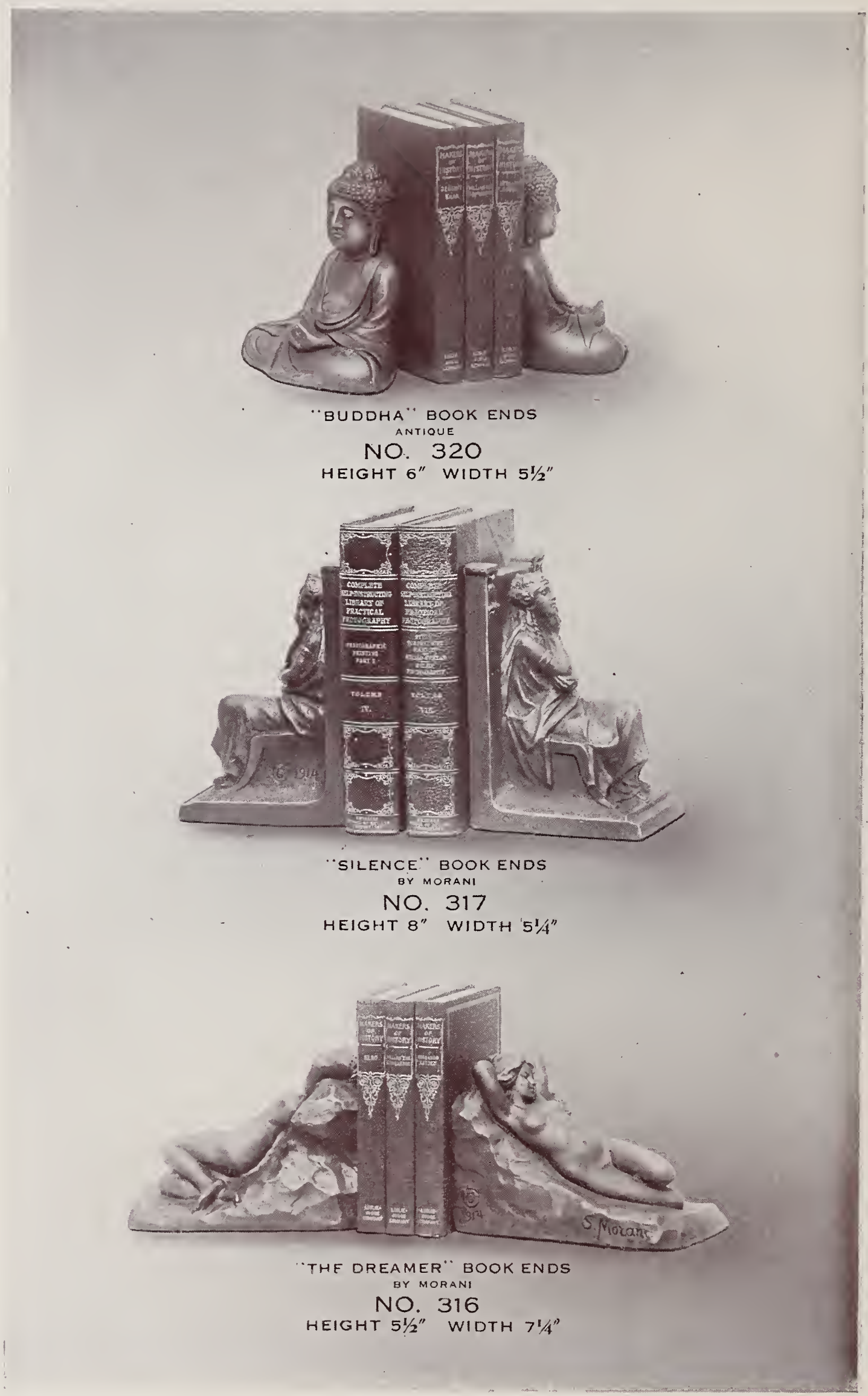




\section{A $\cdot R$ M O R}
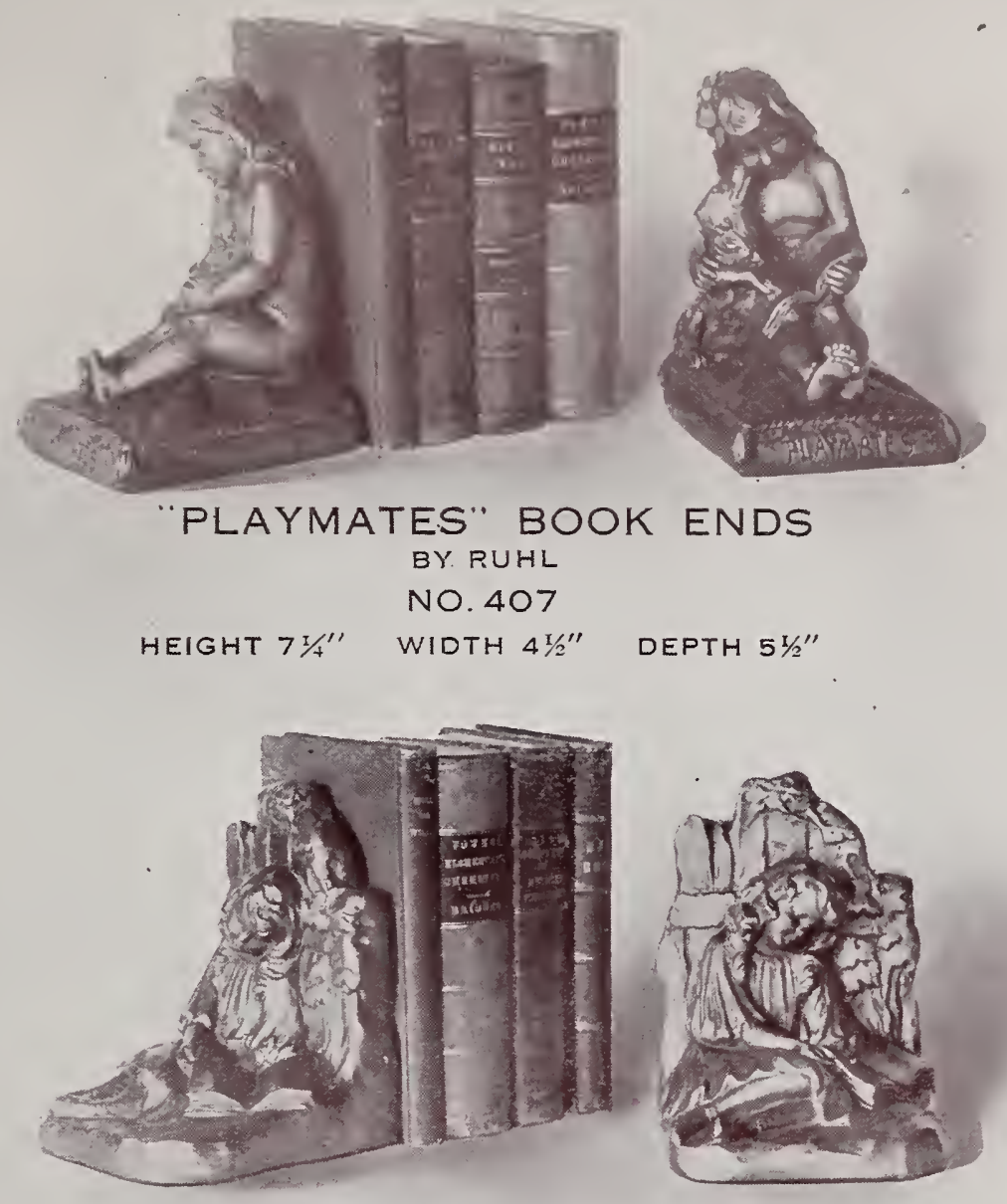

"SLUMBER" BOOK ENDS BY MORANI NO. 404

Price $\$ 8.00$ Pair HEIGHT 71/2" WIDTH $5 \frac{1}{2} 2^{\prime \prime}$ DEPTH 6"

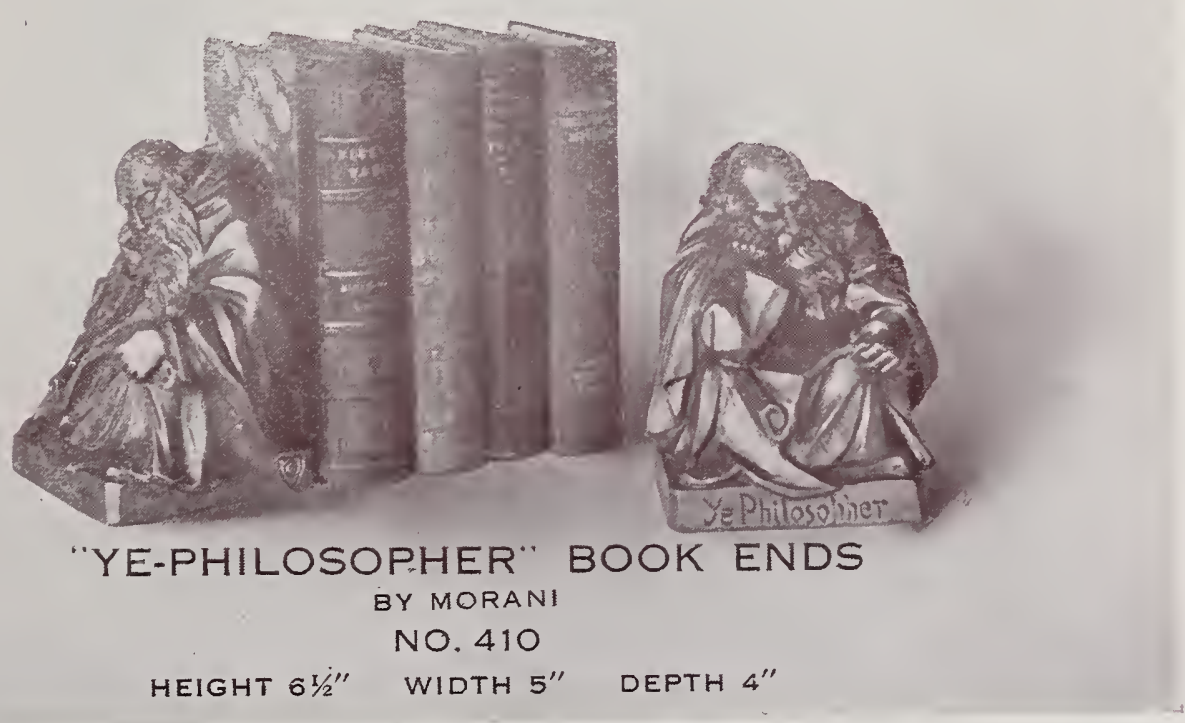




\section{A R M O R}

\section{B R O N Z E}

Price $\$ 9.00$ Pair

Price $\$ 8.00$ Pair

Price $\$ 6.00$ Pair
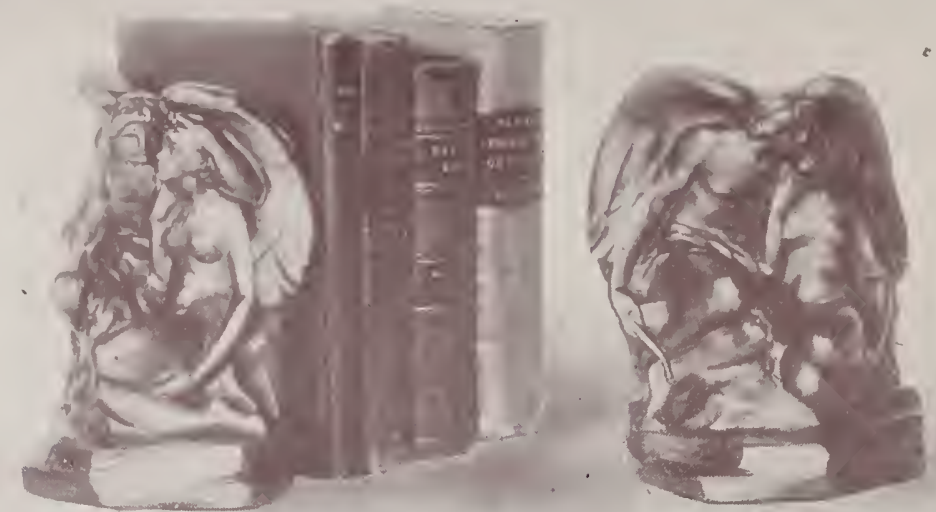

"CUPID AND PSYCHE" BOOK ENDS BY JOHNSON NO. 401

WIDTH $6^{\prime \prime}$

DEPTH 33/4"

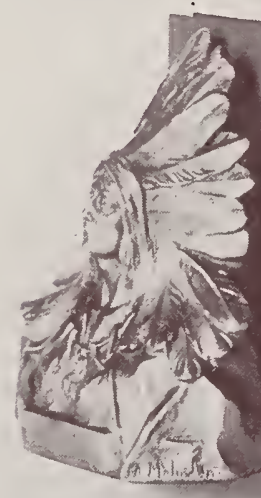

$$
\begin{aligned}
& \text { "INDIAN" BOOK ENDS } \\
& \text { BY MELIODON } \\
& \text { NO. } 405 \\
& \text { HEIGHT 8" WIDTH } 7 " \text { DEPTH } 3 \% \text { " } 4 \text { " }
\end{aligned}
$$
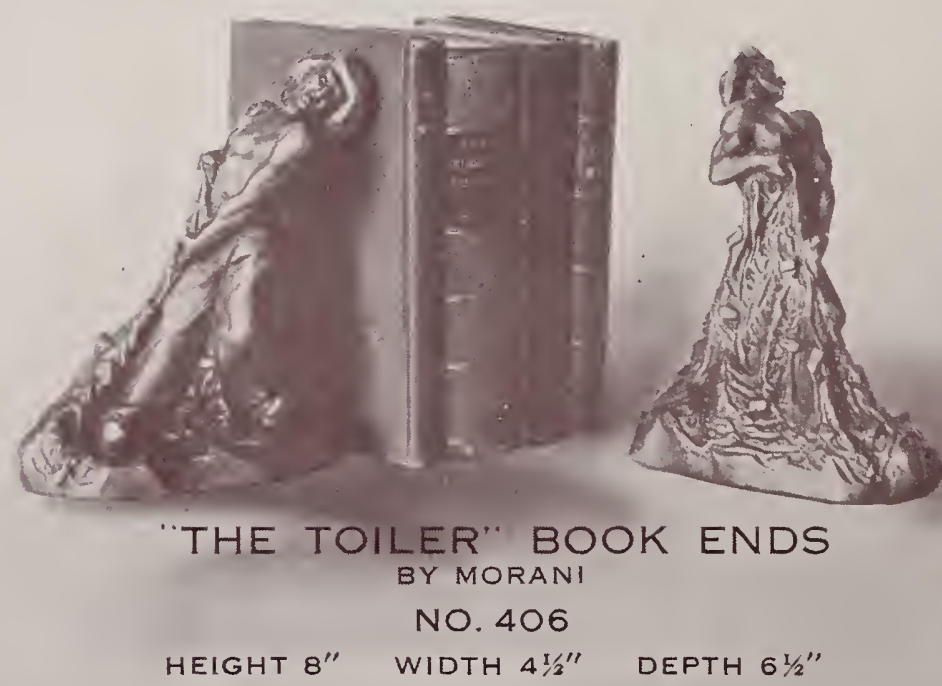


\section{A R M O R}
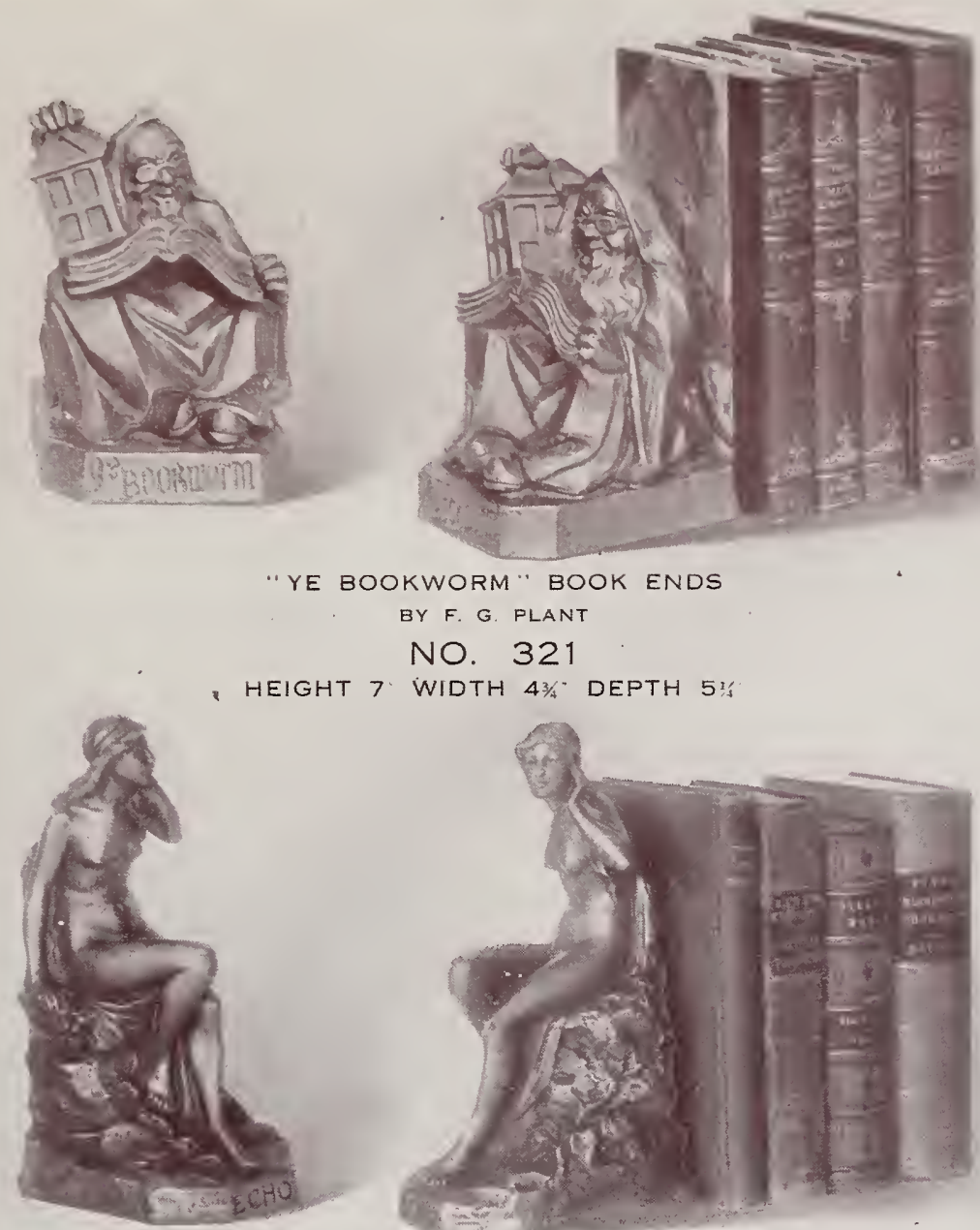

$$
\begin{gathered}
\text { "ECHO" BOOK ENDS } \\
\text { BY RUHL }
\end{gathered}
$$

NO. 326

HEIGHT 9\%/2 WIDTH 4" DEPTH 5
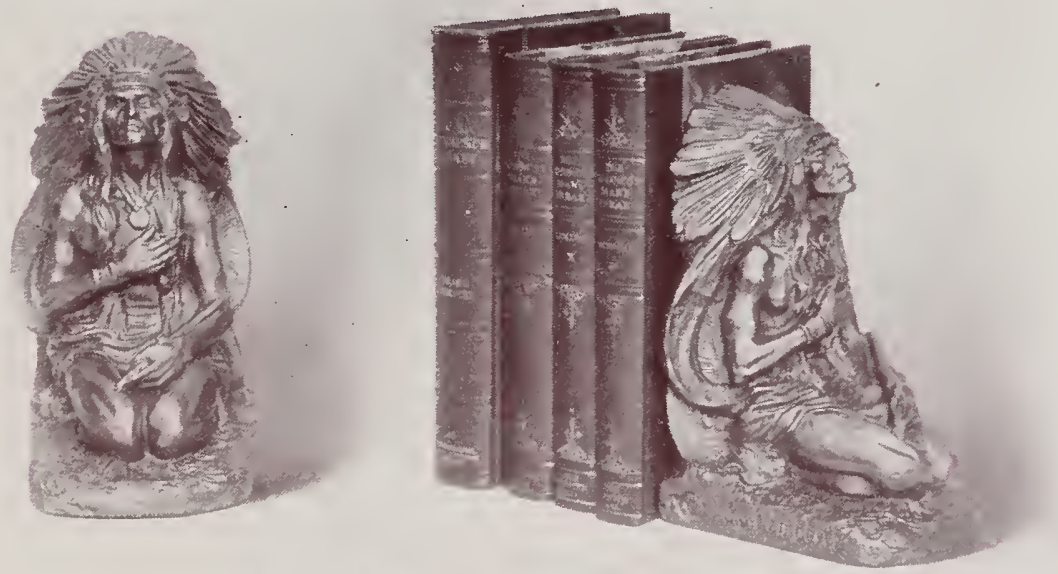

"MEDICINE MAN" BOOK ENDS

NO. 328

HEIGHT 8" WIDTH 41/2" DEPTH 51/4

Price $\$ 10.00$ Pair

\author{
Price $\$ 10.00$ Pais
}




\section{A R M O R}

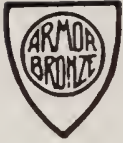

B R O N Z E

Price $\$ 10.00$ Pair
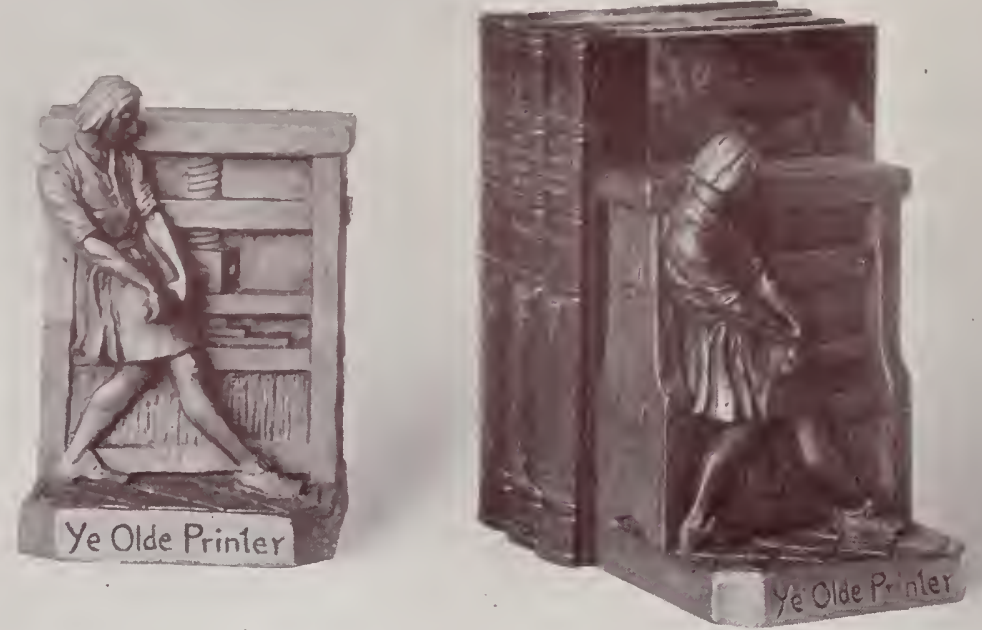

"YE OLDE PRINTER" BOOK ENDS

BY RUHL

NO. 327

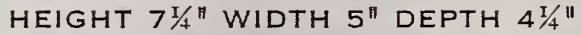
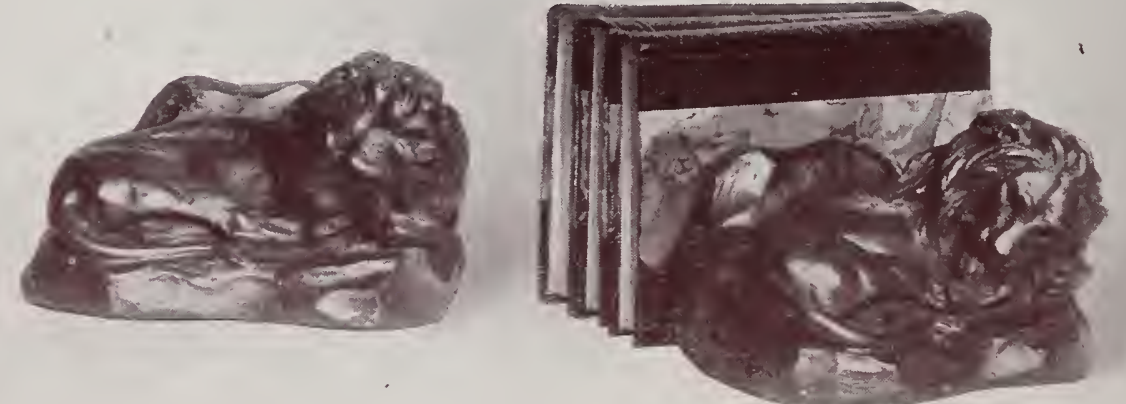

Frice \$9.00 Pair

"REPOSING LION" BOOK ENDS OR DOOR STOP BY MORANI

NO. 322

HEIGHT 5" WIDTH $8^{n}$ DEPTH $6^{n}$
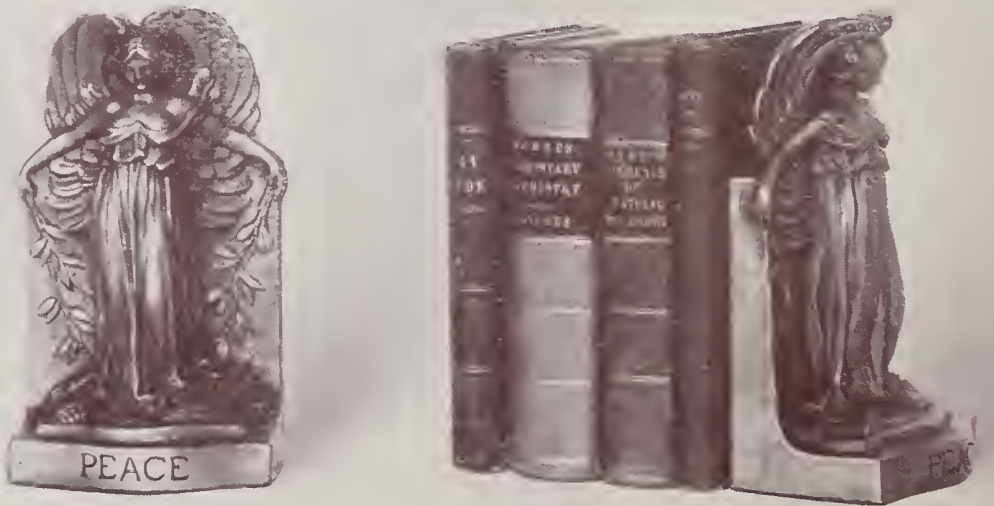

Price $\$ 8.00$ Pair

Price in

Polychrome

$\$ 12.00$ Pair

"PEACE" BOOK ENDS

NO. 323

HEIGHT $8^{1 / 2 n}$ WIDTH $4^{3 / 4} 4^{n}$ DEPTH $3^{1 / 2} 2^{n}$ 


\section{A R M O R}

\section{B R O N Z E}

Price $\$ 9.00$ Pair

$$
\begin{gathered}
\text { "LION" BOOK ENDS } \\
\text { BYRUHL } \\
\text { NO. } 338
\end{gathered}
$$

HEIGHT 7" WIDTH 7" DEPTH 4"
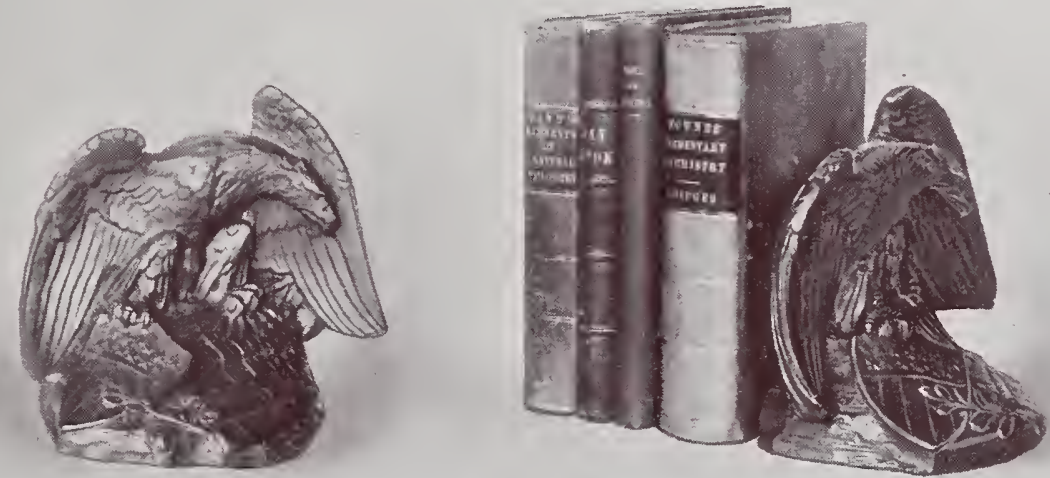

$$
\begin{gathered}
\text { "EAGLE" BOOK ENDS } \\
\text { BY RUHL }
\end{gathered}
$$

NO. 337

HEIGHT $7^{\pi}$ WIDTH $5^{n}$ DEPTH $5^{\text {" }}$

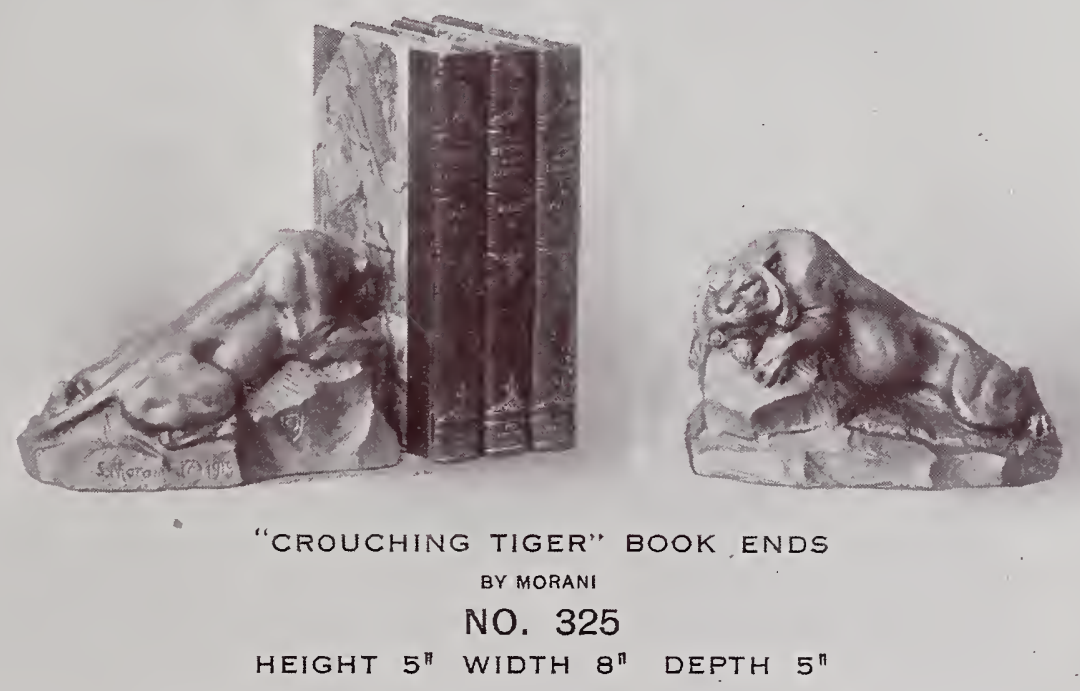

Price $\$ 8.00$ Pair Price in Polychrome $\$ 12.00$ Pair 
Price $\$ 9.00$ Pair

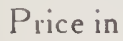

Po!ychrome

$\$ 12.00$ Pair

Price $\$ 12.00$ Pair

Price $\$ 8.00$ Pair

Price in

Polychrome

$\$ 12.00$ Pair

\section{A R M O R}

B R O N Z E
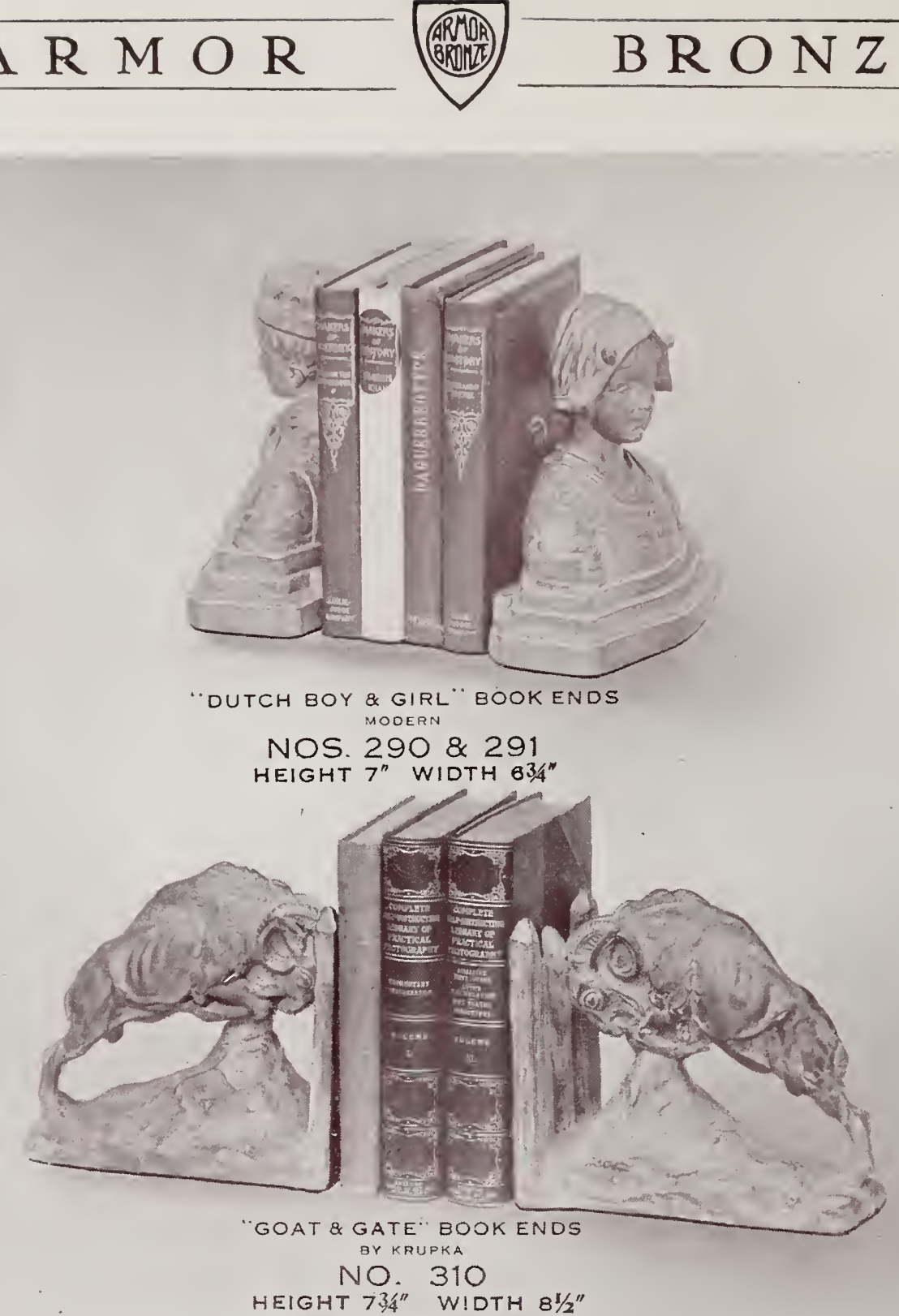

HEIGHT 73/" W!DTH $81 / 2 "$

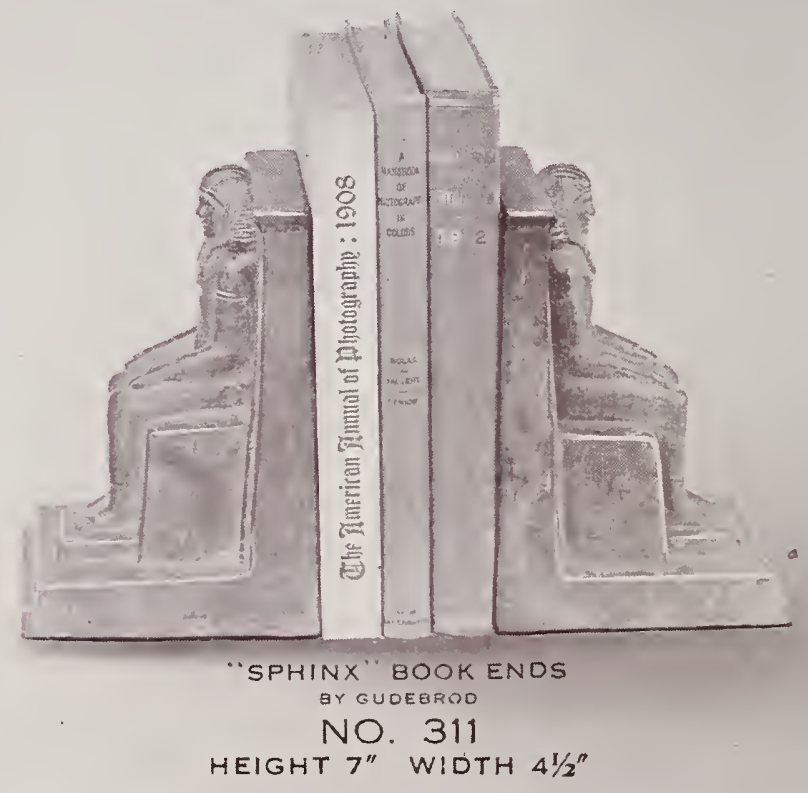

HEIGHT 7" WIDTH $4 \frac{1}{2} 2^{\prime \prime}$ 


\section{A R M O R}
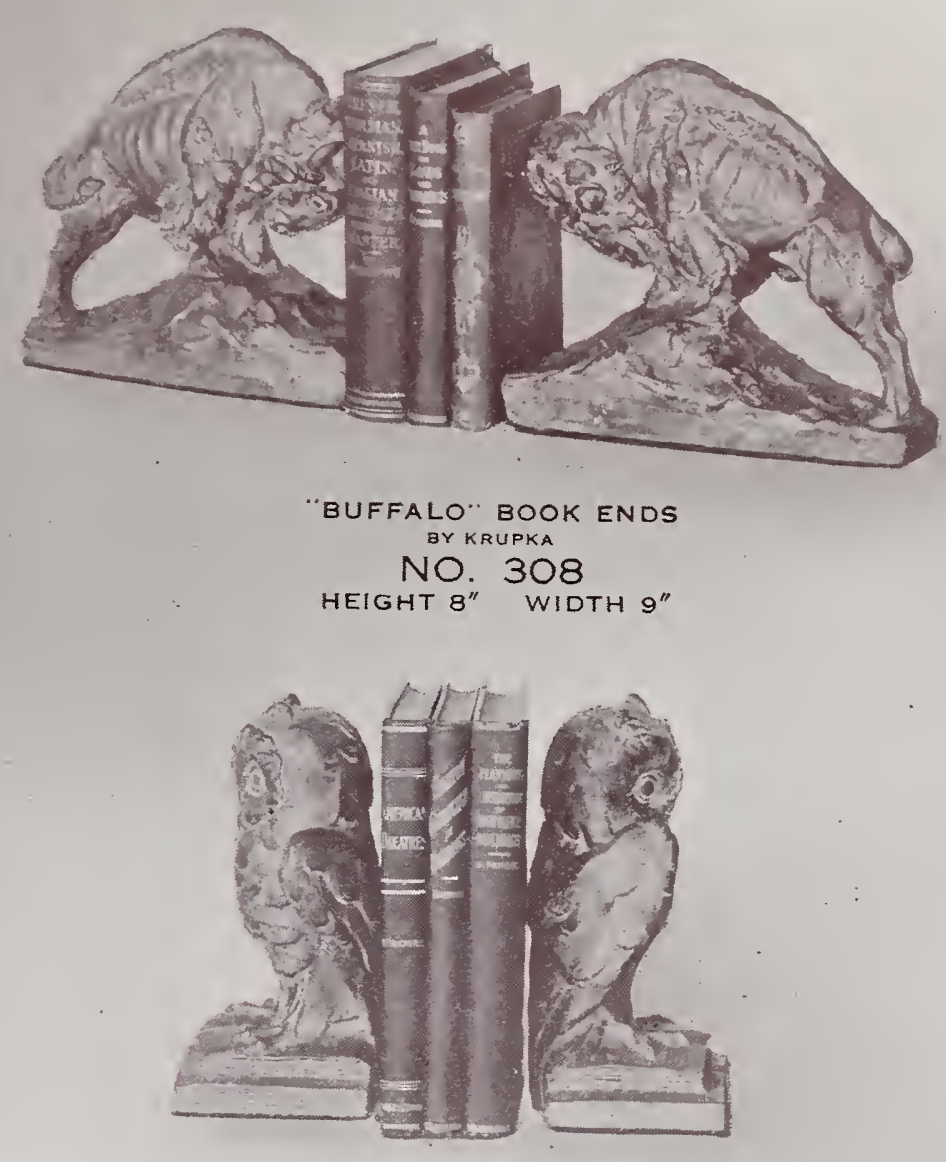

"OWL" BOOK ENDS
3Y KRUPKA
NO. 309
HEIGHT 9 " WIDTH $5 "$

Price \$10.00 Pair

Price \$10.00 Pair

Price \$10.00 Pair

Price $\$ 10.00$ Pair

\section{THE NATIONAL METALIZING COMPANY}




\section{A R M O R}

\section{B R O N Z E}

Price $\$ 10.00$ Pair

Price $\$ 12.00$ Pair

Price $\$ 12.00$ Pair Price in Polychrome $\$ 16.00$ Pai:

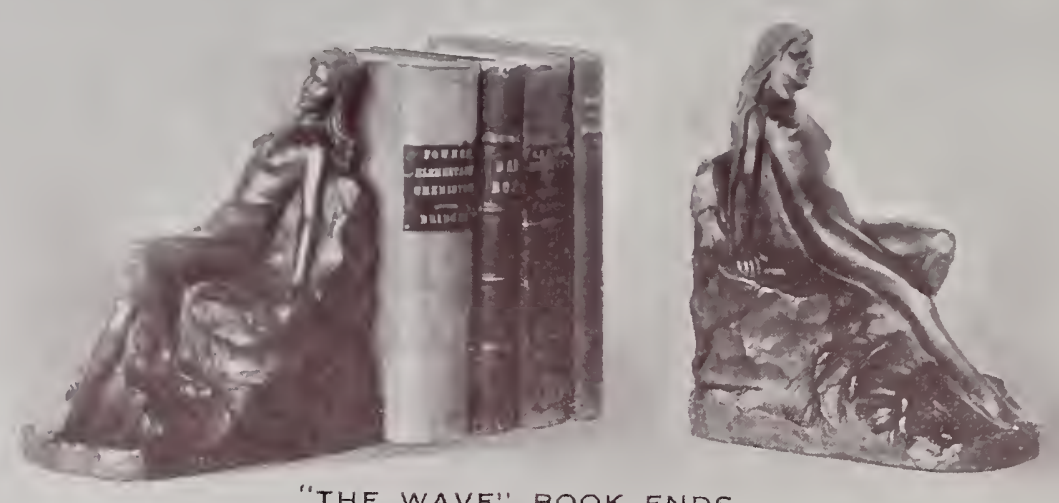

"THE WAVE" BOOK ENDS

BY RUHL

NO. 339

HEIGHT $8 \frac{1}{4} 4^{n}$ WIDTH $7^{\prime \prime}$ DEPTH $5^{n}$

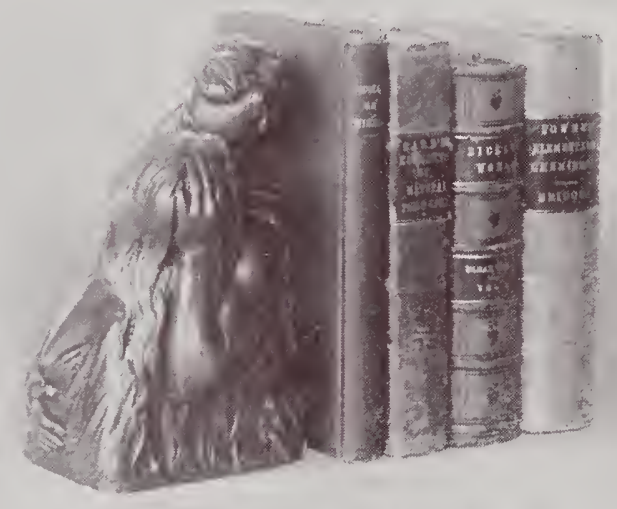

"THE KISS" BOOK ENDS

BY RUHL

NO. 340

HEIGHT $8^{B}$ WIDTH $4 \frac{1}{2}$ " DEPTH. $5^{\text {" }}$
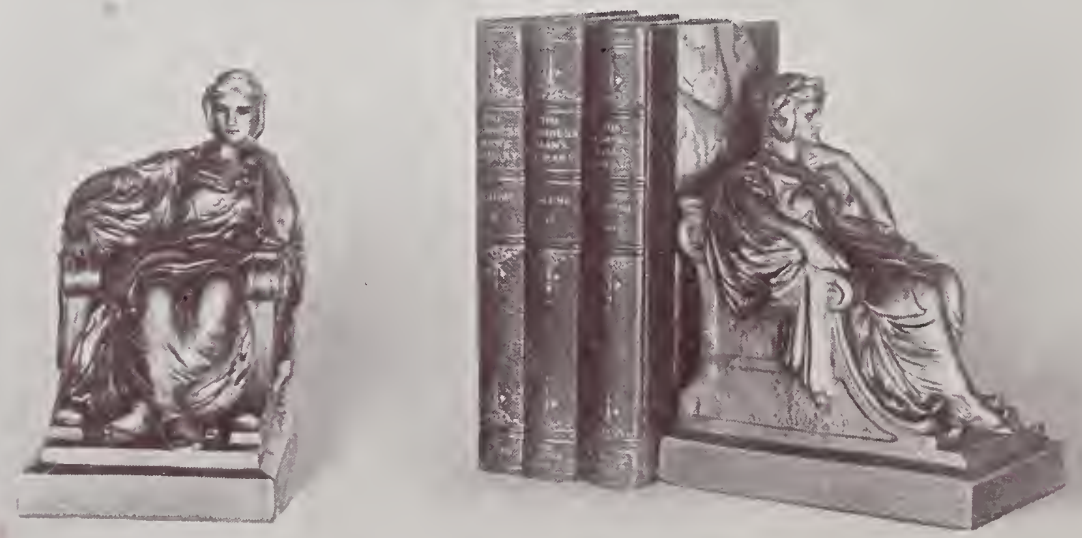

"KNOWLEDGE" BOOK ENDS

BY JOHNSON

NO. 330

HEIGHT 8" WIDTH 6 $1 / 2$ " DEPTH $4 \frac{3}{4}$ " $^{n}$ 
A R M O R

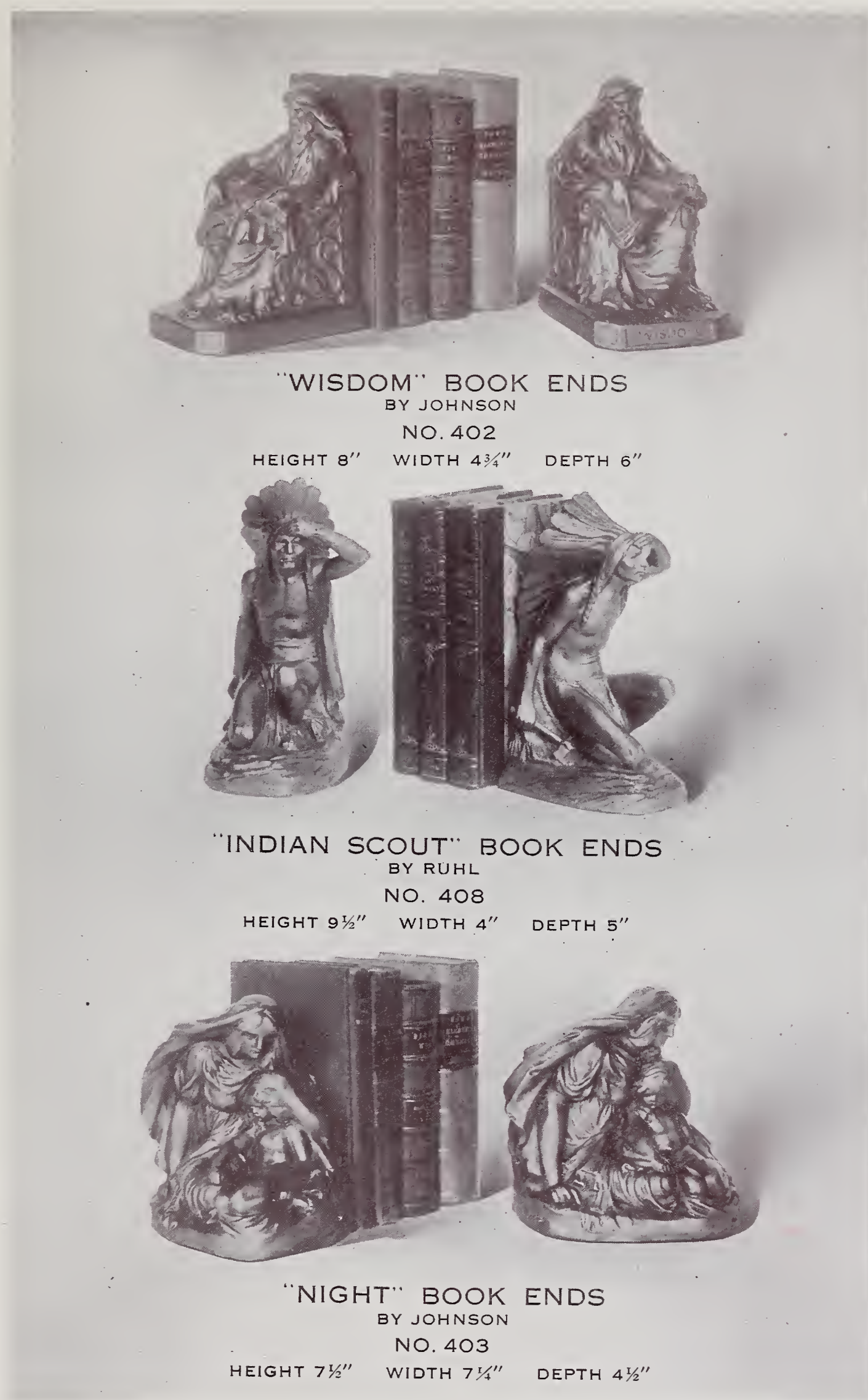

Price $\$ 12.00$ Pair

Price in

Polychrome

$\$ 16.00$ Pair

Price $\$ 12.00$ Pair

Price $\$ 12.00$ Pair 


\section{A R M O R}

Price $\$ 15.00$ Pair

Price in

Polychrome

$\$ 20.00$ Pair

Price $\$ 12.00$ Pair

Price $\$ 9.00$ Pair

Price in

Polychrome

$\$ 12.00$ Pair

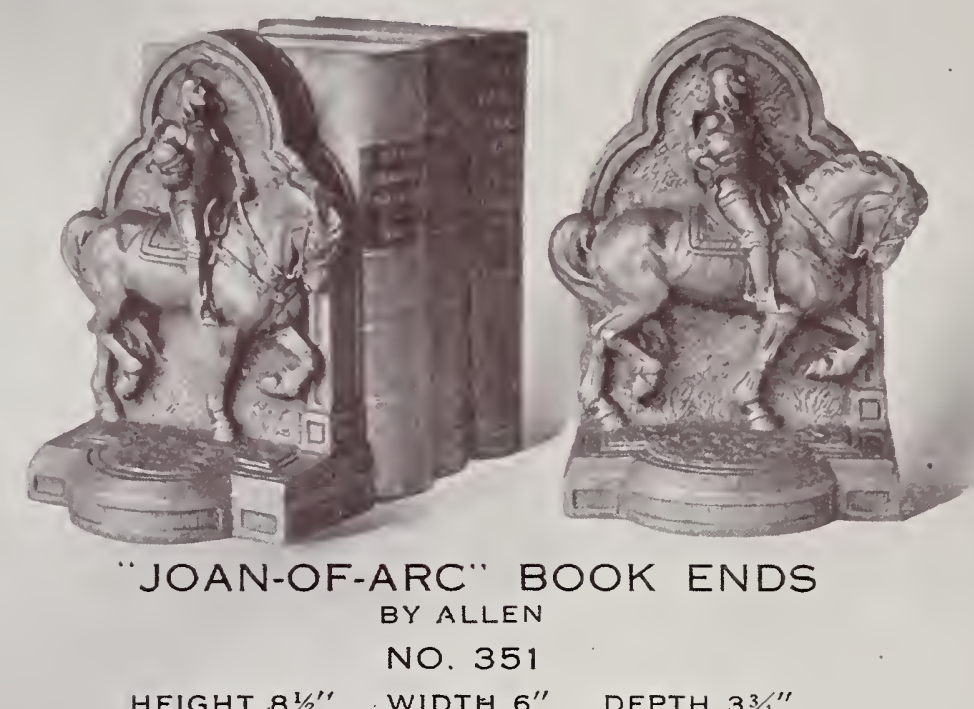

HEIGHT $81 / 2 "$ WIDTH 6 " DEPTH $33 / 4 "$

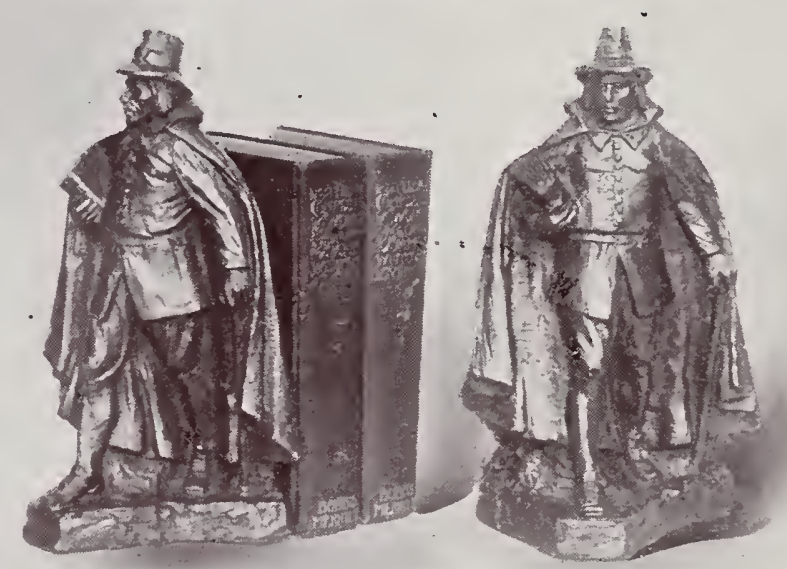

"PURITAN" BOOK ENDS BY RUHL

NO. 343

HEIGHT 101/2" WIDTH $4 \frac{1}{2} 2^{\prime \prime}$ DEPTH 6 "

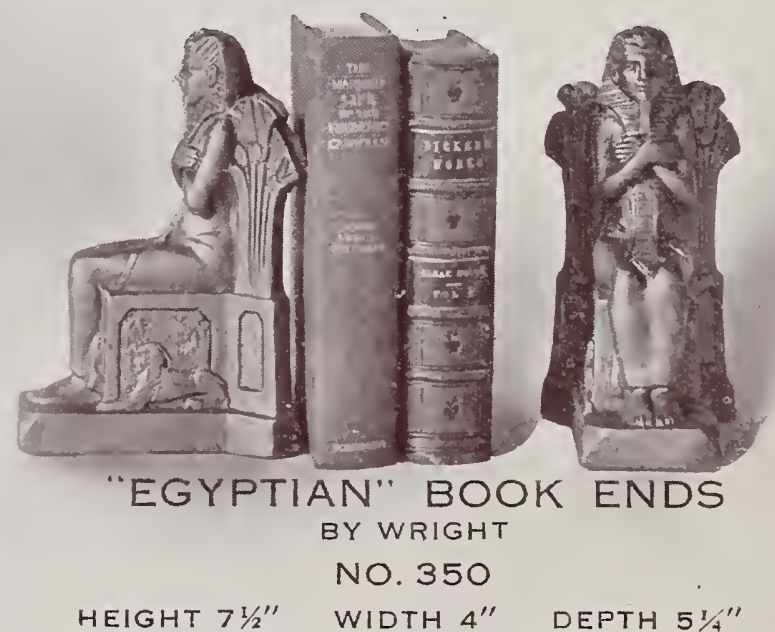

HEIGHT 71/2" WIDTH 4 " DEPTH $51 / 4^{\prime \prime}$ 


\section{A R M O R}

\section{B R O N Z E}
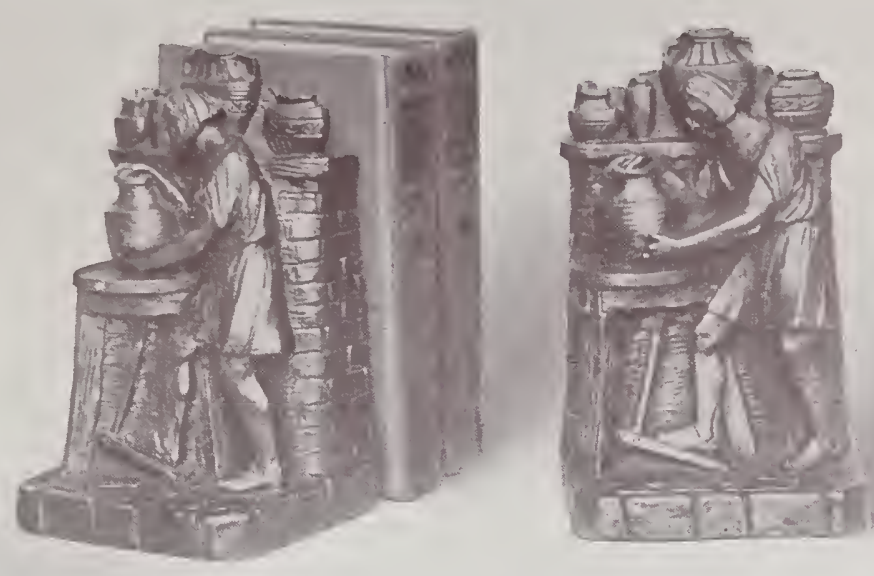

'THE POTTER" BOOK ENDS BY FUHL NO. 342 WIDTH 5", DEPTH $41 / 4^{\prime \prime}$

HEIGHT $8^{\prime \prime}$

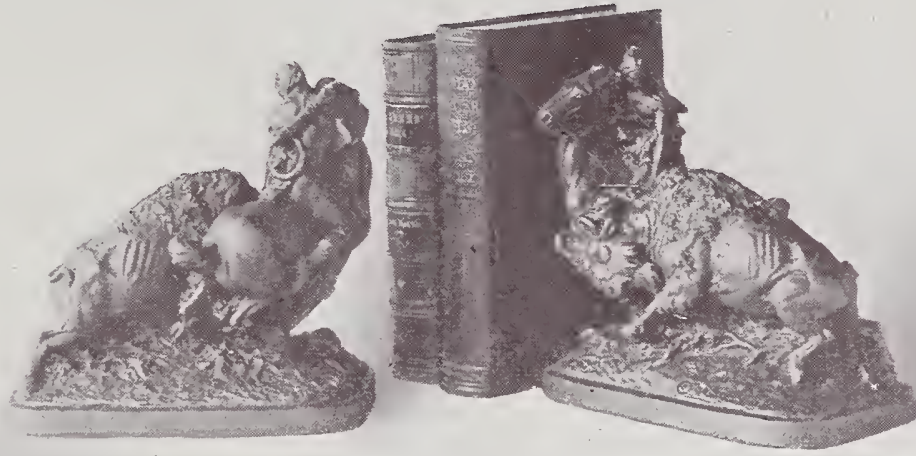
BUFFALO HUNTER". BOOK ENDS BY ALLEN NO. 353 HEIGHT 71/2" WIDTH $7 \frac{1}{2} 2^{\prime \prime}$ DEPTH 4\%"
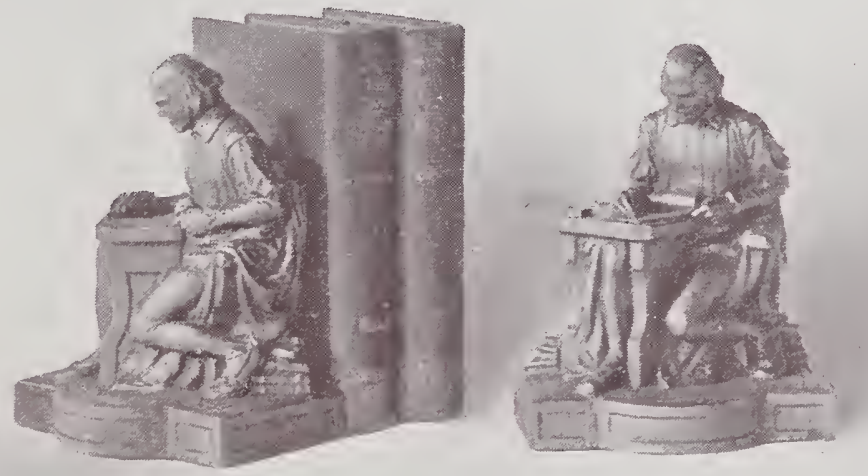

SHAKESPEARE" BOOK ENDS BY ALLEN NO. 352

HEIGHT 7" WIDTH 6"
Price $\$ 10.00$ Pair Price in Polychrome $\$ 15.00$ Pair

Price $\$ 20.00$ Pair

Price $\$ 12.00$ Pair Price in Polychrome $\$ 16.00$ Pair 


\section{A R M OR B RONZE}

Price $\$ 12.00$

Price in

Polychrome

Finish $\$ 17.00$

Price $\$ 14.00$

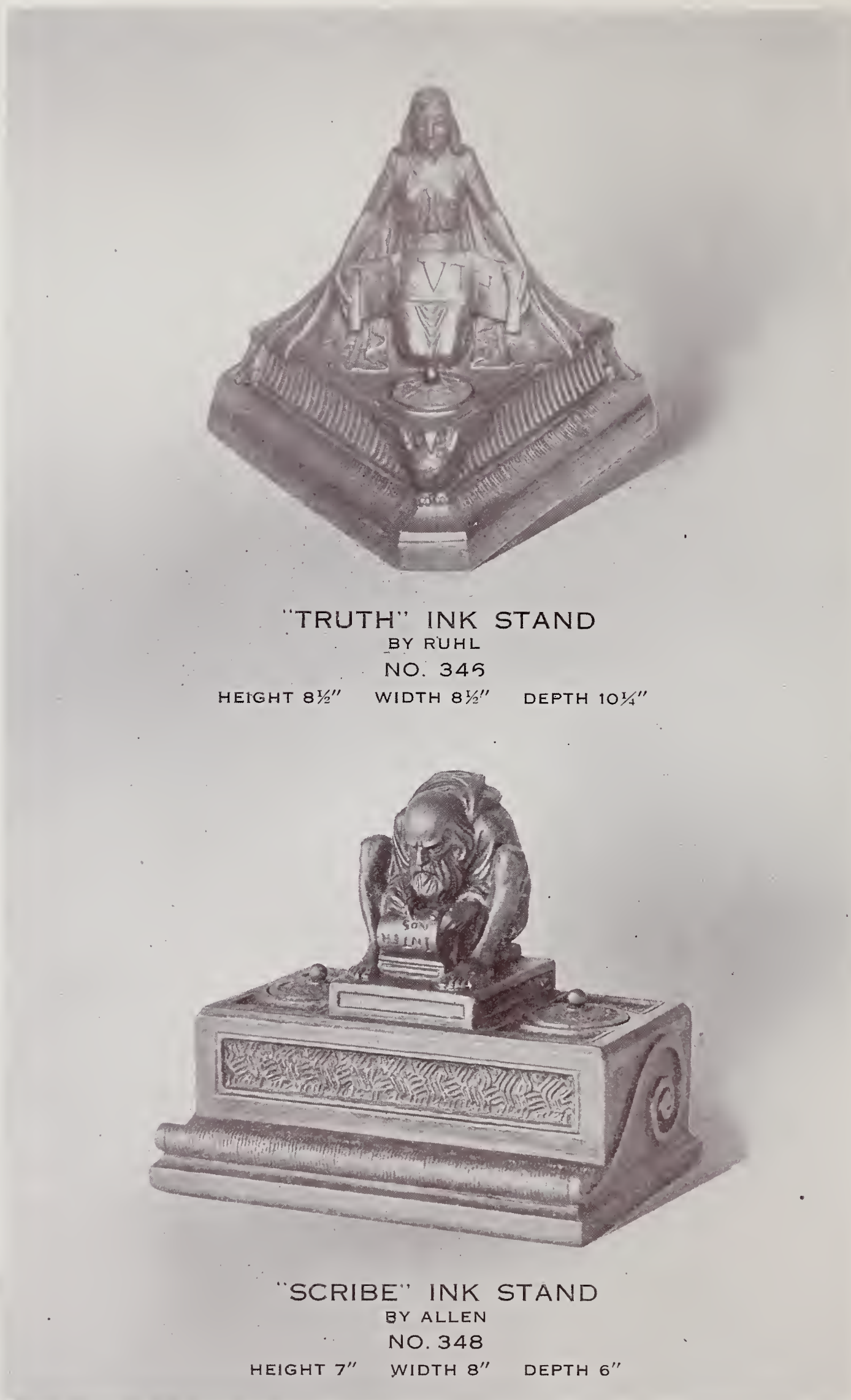


A R M O R

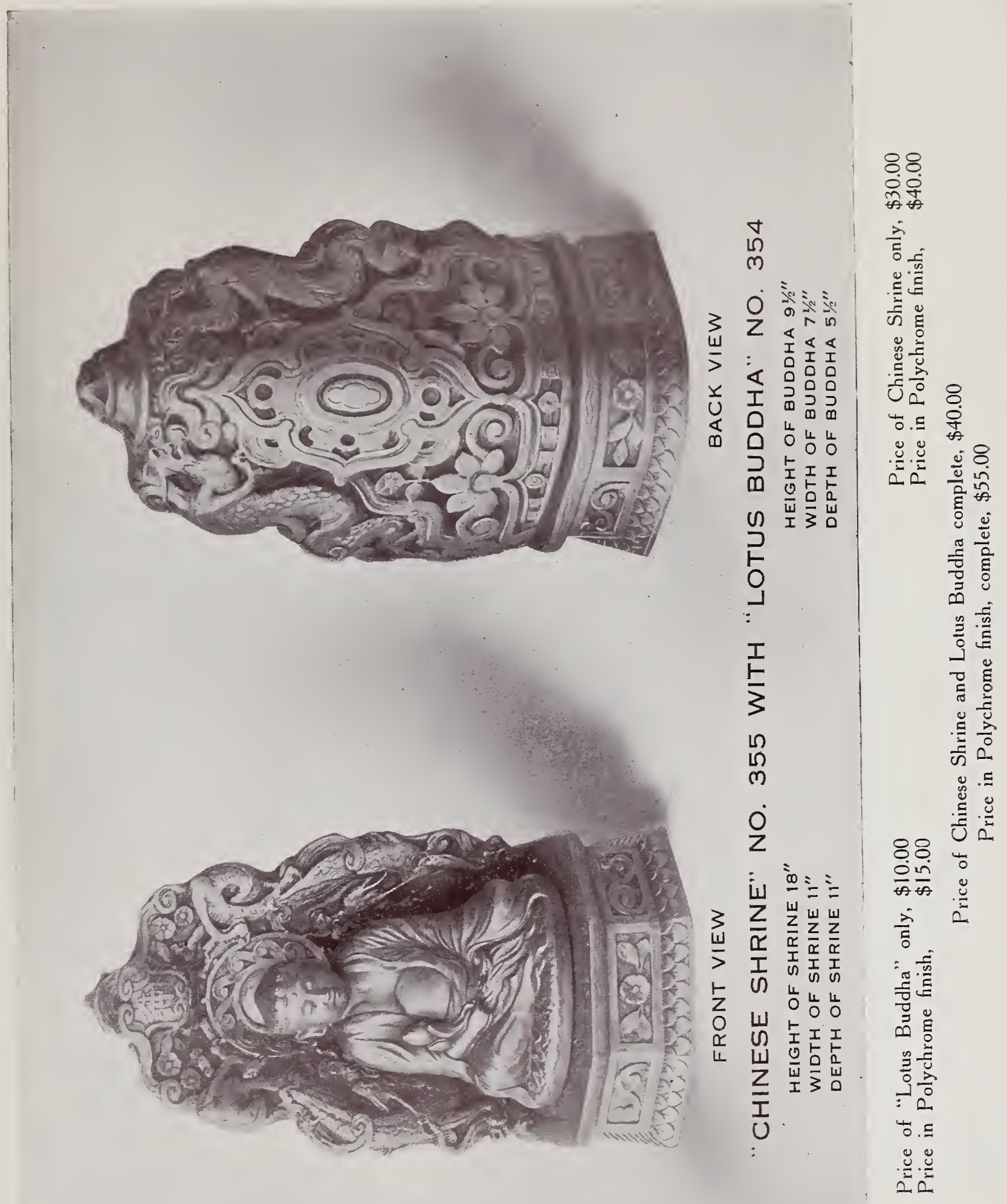




\section{A R M O R}

\section{B R O N Z E}

Price complete with Etched and Painted Bowl No. $\mathrm{PB} / 87$ $\$ 60.00$

Price with Plain Etched Bowl No. B $/ 86, \$ 40.00$

Price without

Bowl, $\$ 30.00$
Price complete with Crystal

Aquarium, $\$ 36.00$
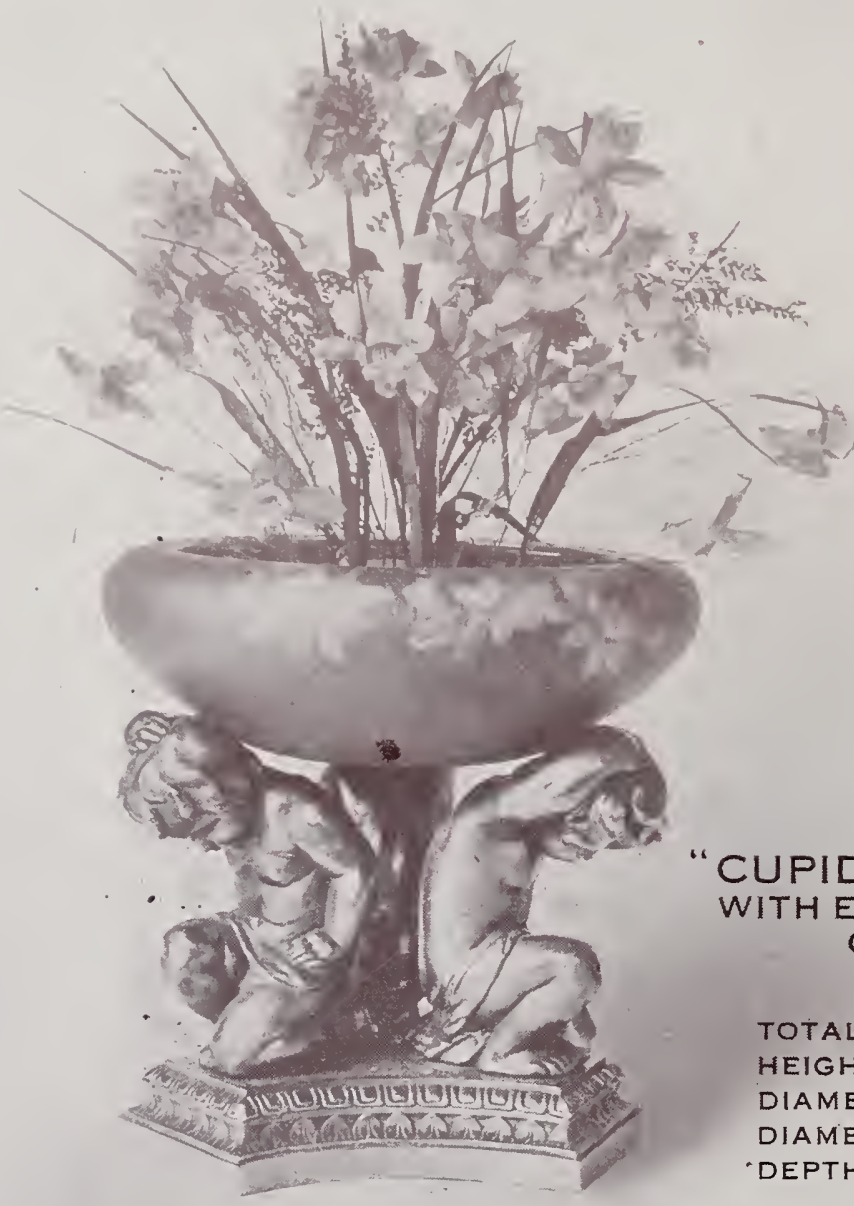

NO. 347

"CUPID" BOWL HOLDER WITH ETCHED AND PAINTED GLASS BOWL NO. P.B./87

TOTAL HEIGHT $15^{\prime \prime}$ HEIGHT OF BOWL HOLDER $n$ " DIAMETER OF BASE 10" DIAMETER OF BOWL 15" DEPTH. OF BOWL 5"

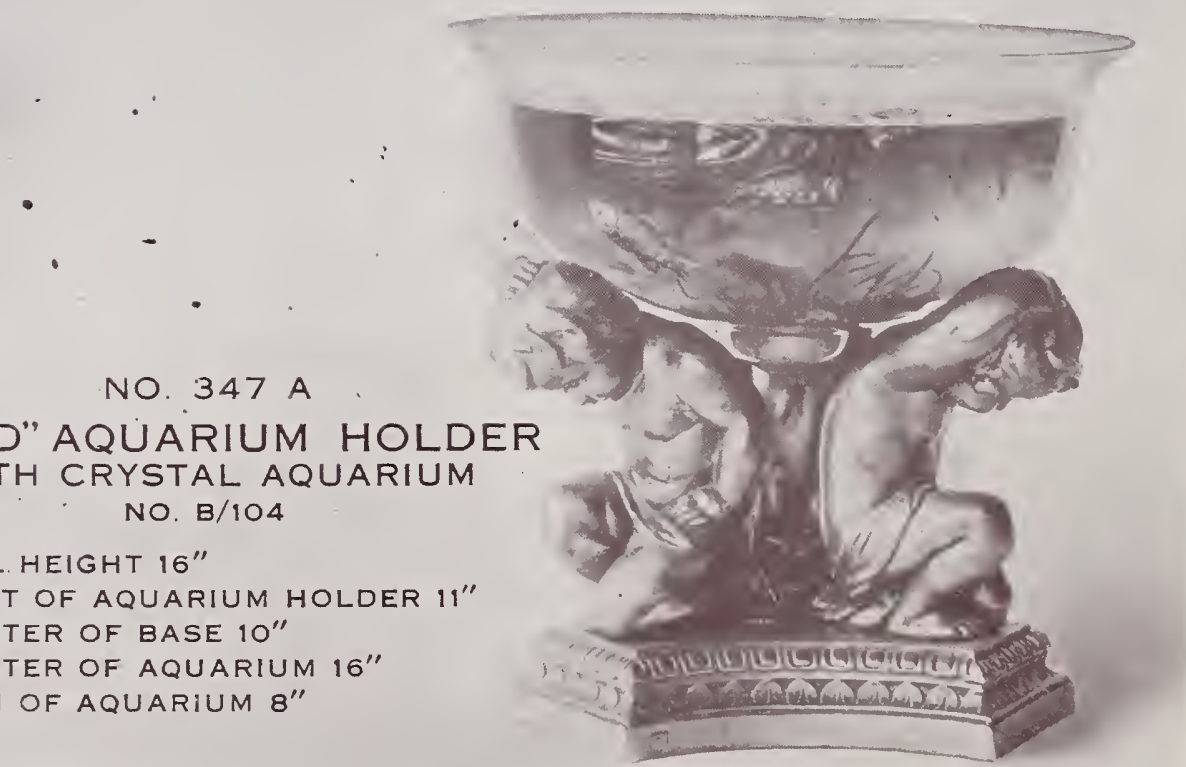




\section{A R M O R}

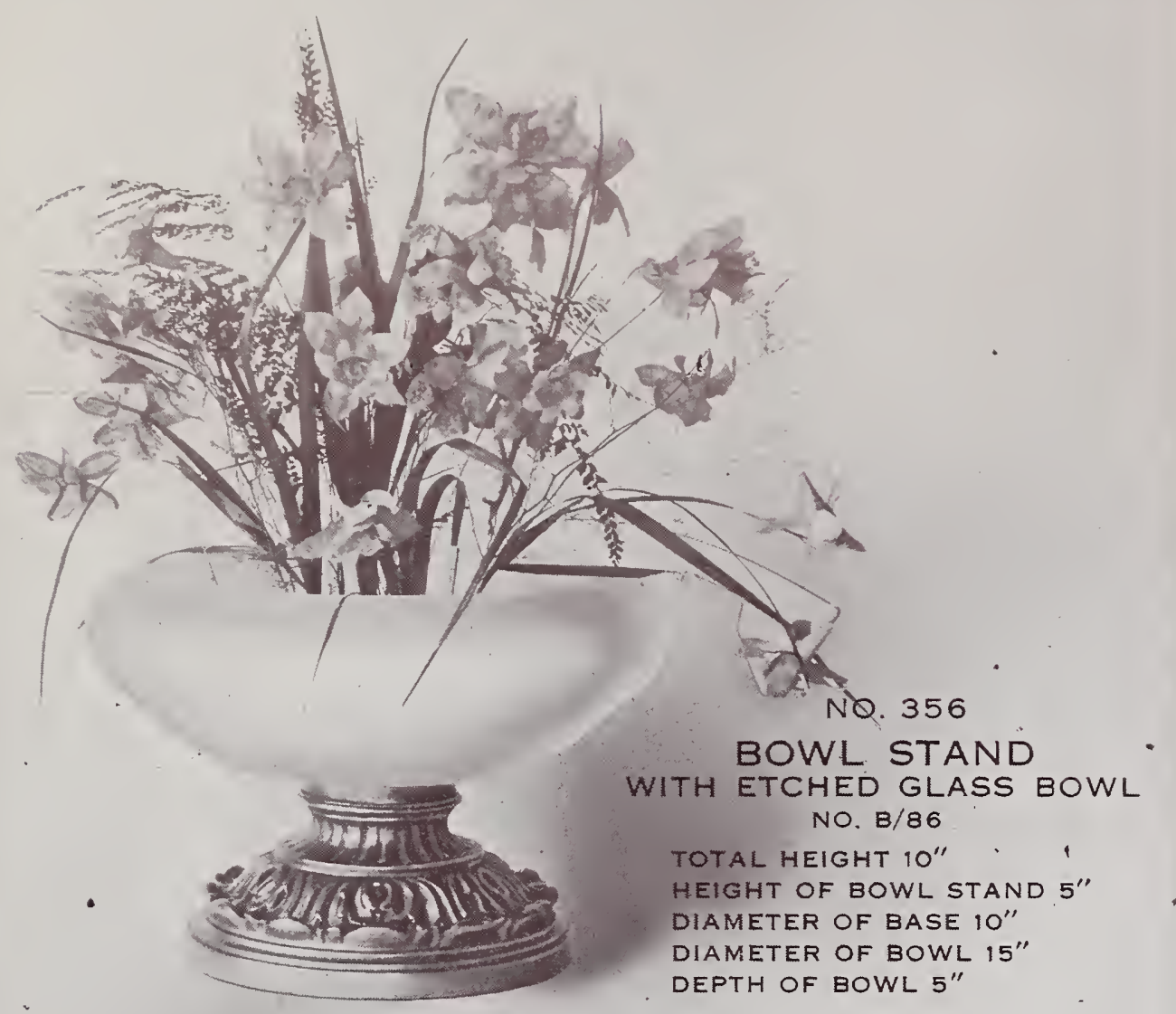

Price complete with Plain Etched Bow! $\$ 22.00$

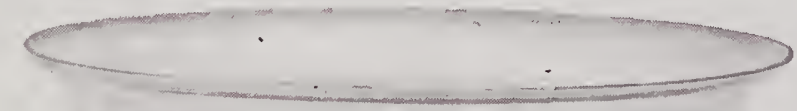

NO. 356 A

AQUARIUM STAND WITH CRYSTAL AQUARIUM NO. B/104

TOTAL HEIGHT 12"

HEIGHT OF AQUARIUM STAND 5" DIAMETER OF BASE 10" DIAMETER OF AQUARIUM 16" DEPTH OF AQUARIUM $8^{\prime \prime}$

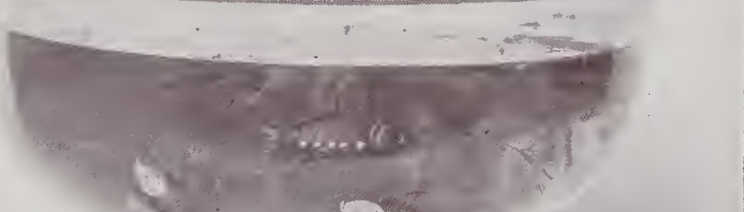

Price complete with Crystal

Aquarium, $\$ 18.00$ 


\section{$\overline{\mathrm{AR} \mathrm{M} \mathrm{O} \mathrm{R}}$}

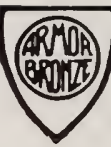

B R O N Z E

Price \$11.00 Each Price in

Polychrome

$\$ 15.00$ Each

Price $\$ 9.00$
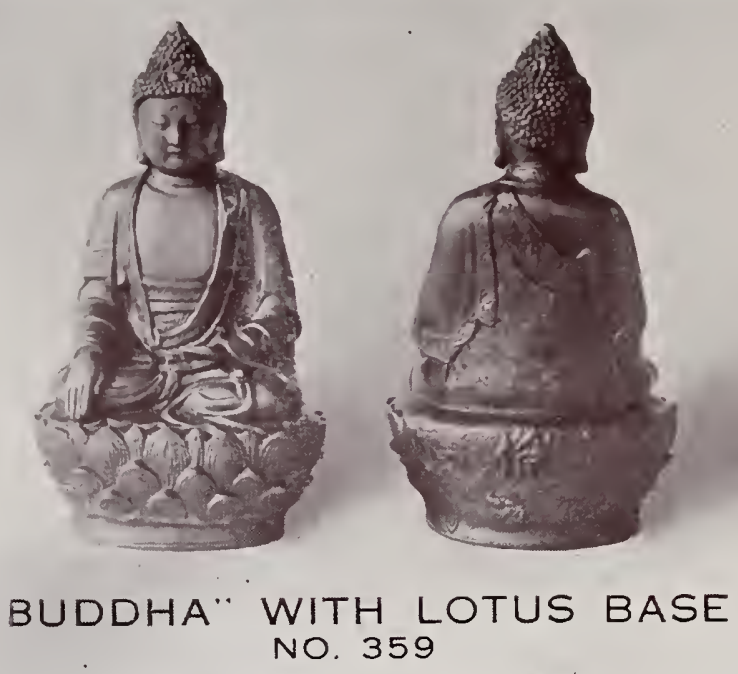

HEIGHT 101/2" WIDTH. 6/1/2"

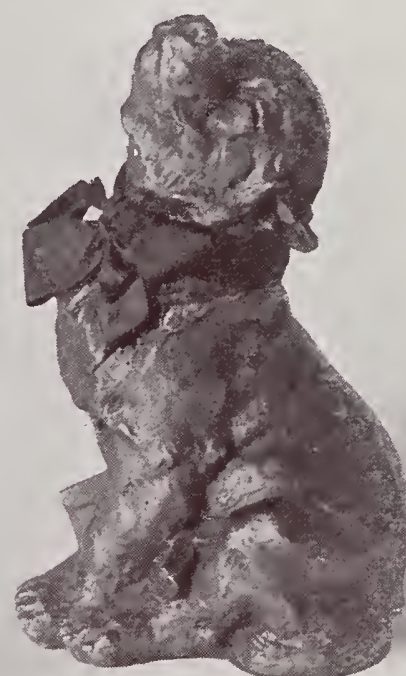
TROUBLED PUP" DOOR STOP BY ROTH
NO. 206

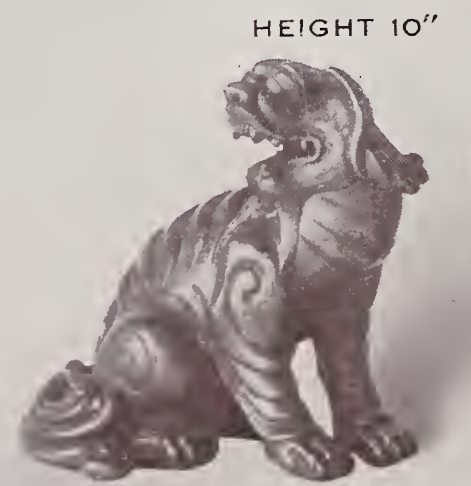

WIDTH $6^{\prime \prime}$

"CHINESE DOG" NO. 345

HEIGHT $9^{\prime \prime}$

WIDTH 9"

THE NATIONAL METALIZING COMPANY 
A R M O R
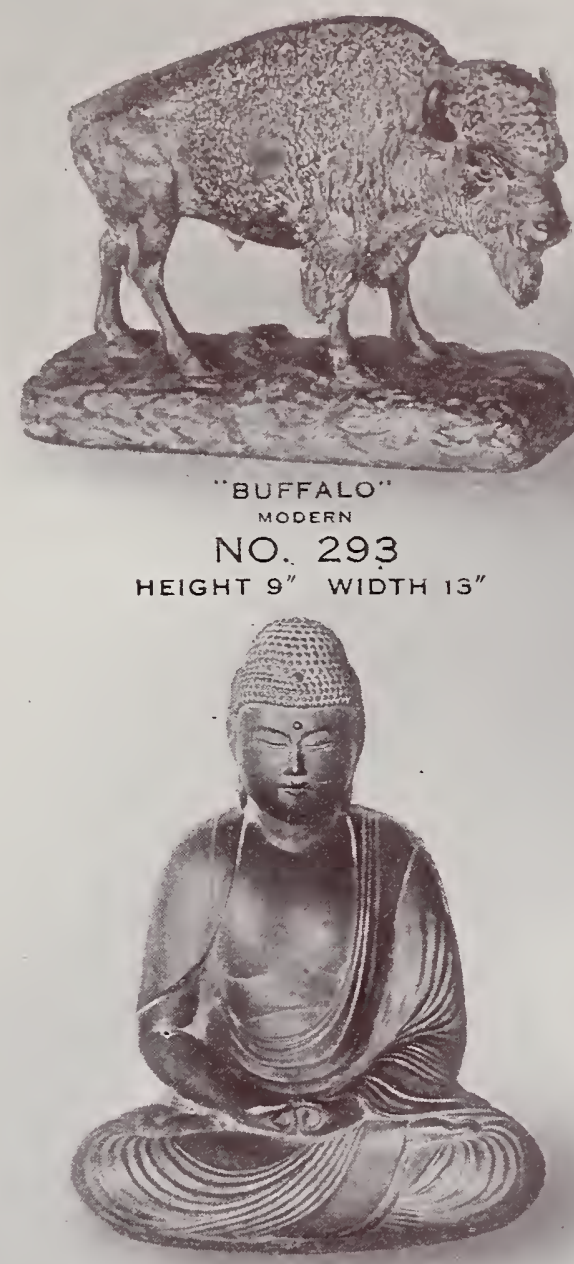

"BUDDHA"

NO. 296

HEIGHT 12, 1/2" WIDTH 101/2"

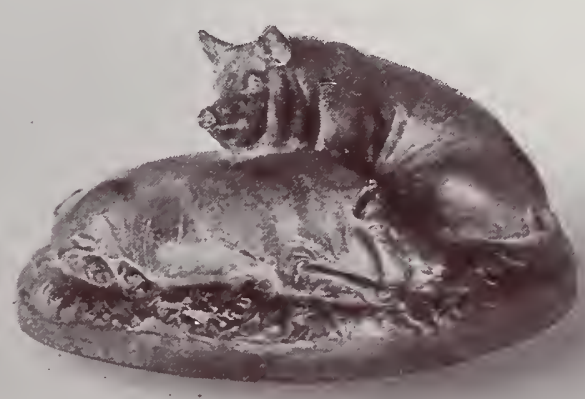

PIGS"

NO. 294

HEIGHT 61/2" WIDTH 121/2"

Price $\$ 16.00$

Price in

Polychrome

and Sgraffito

Finish, $\$ 24.00$ 


\section{A R M O R}

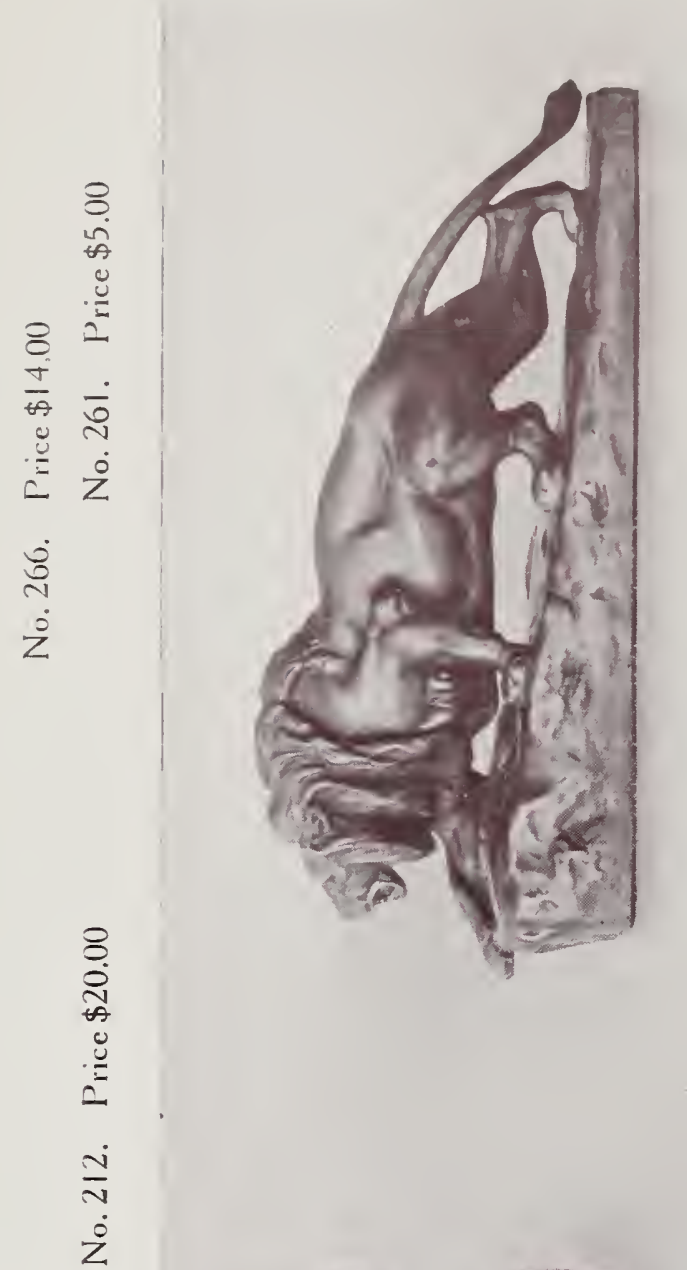

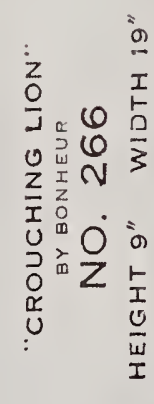
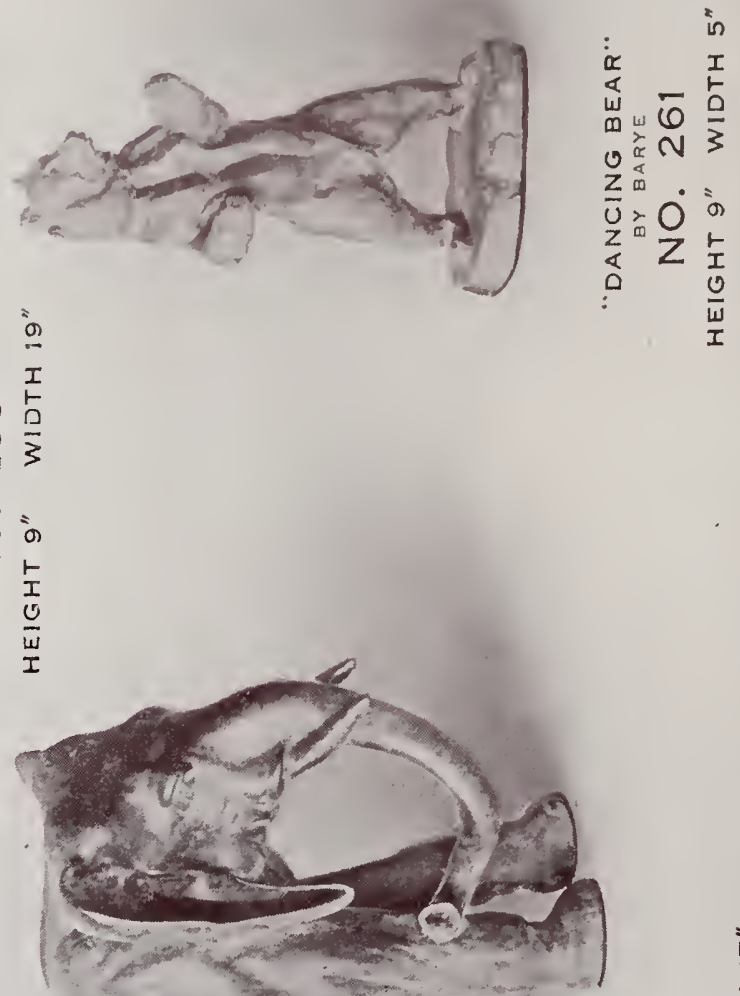

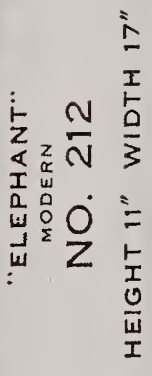

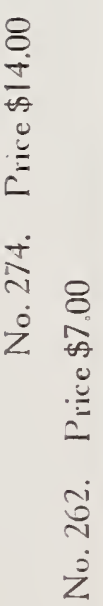
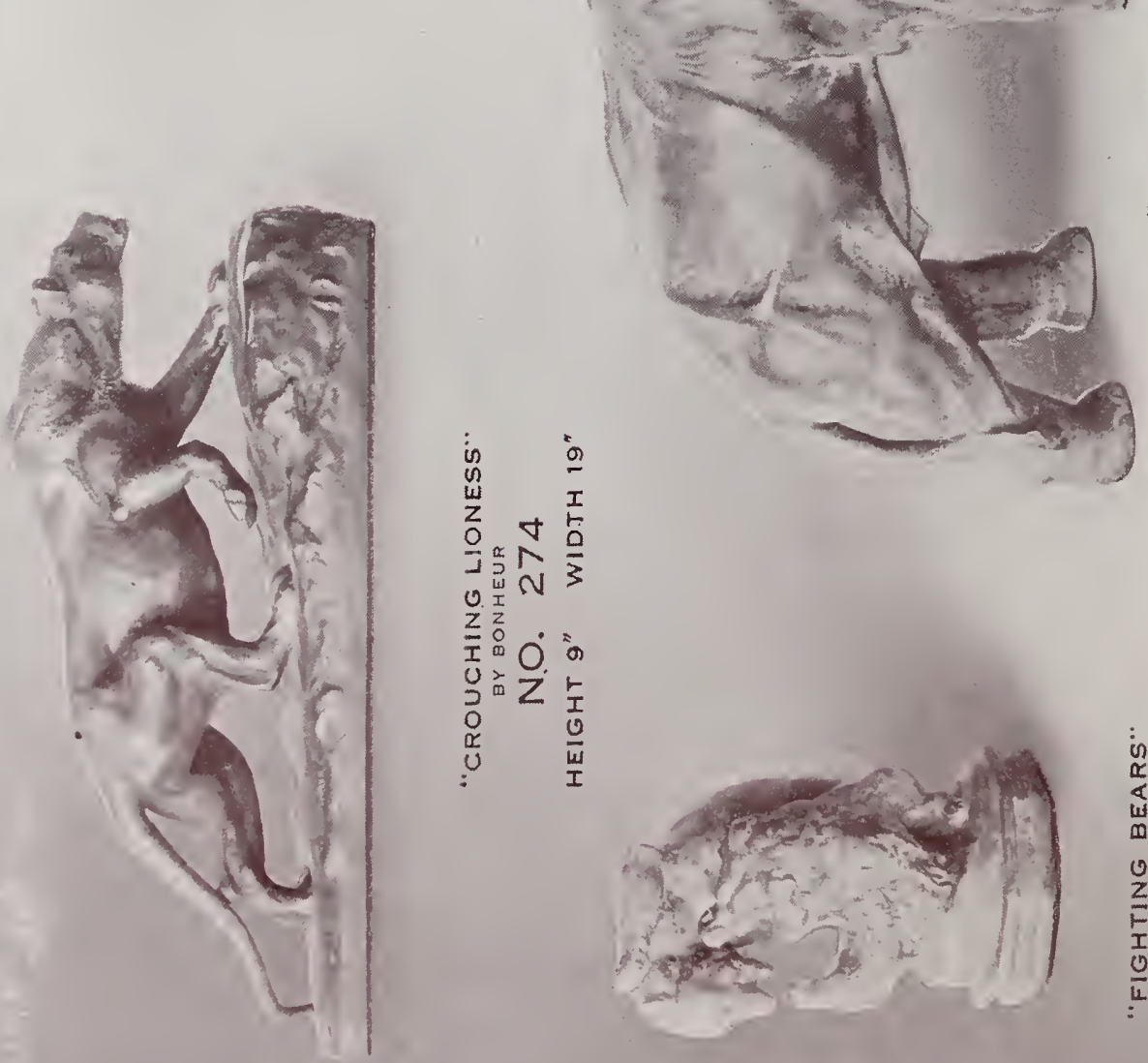

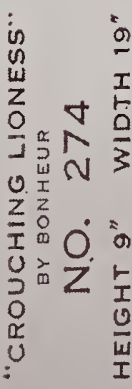

THE NATIONAL METALIZING COMPANY 
A R M O R
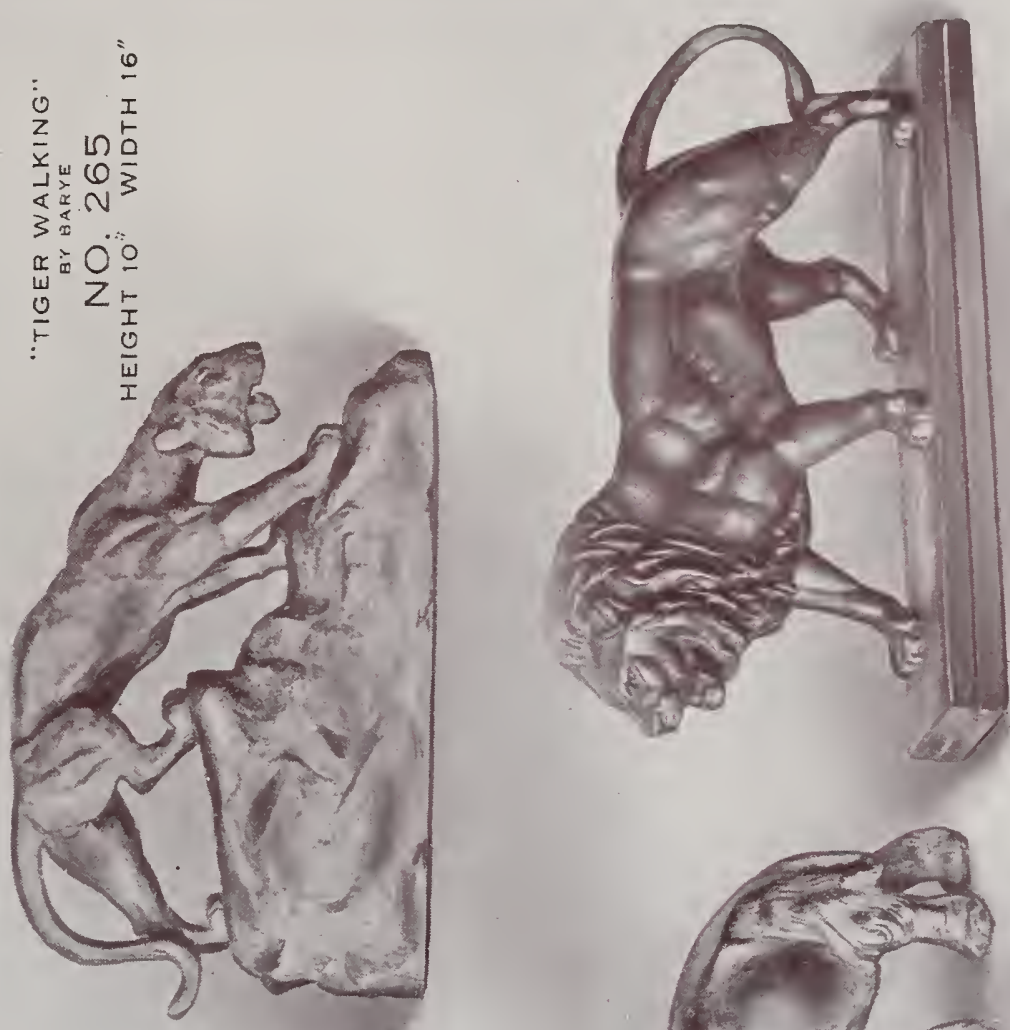

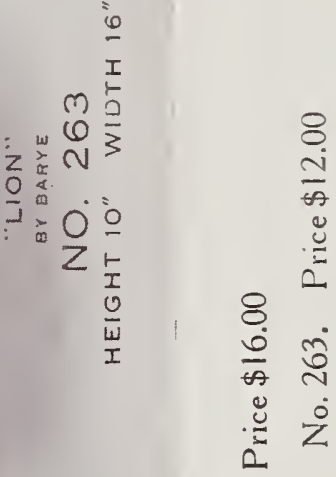

iे
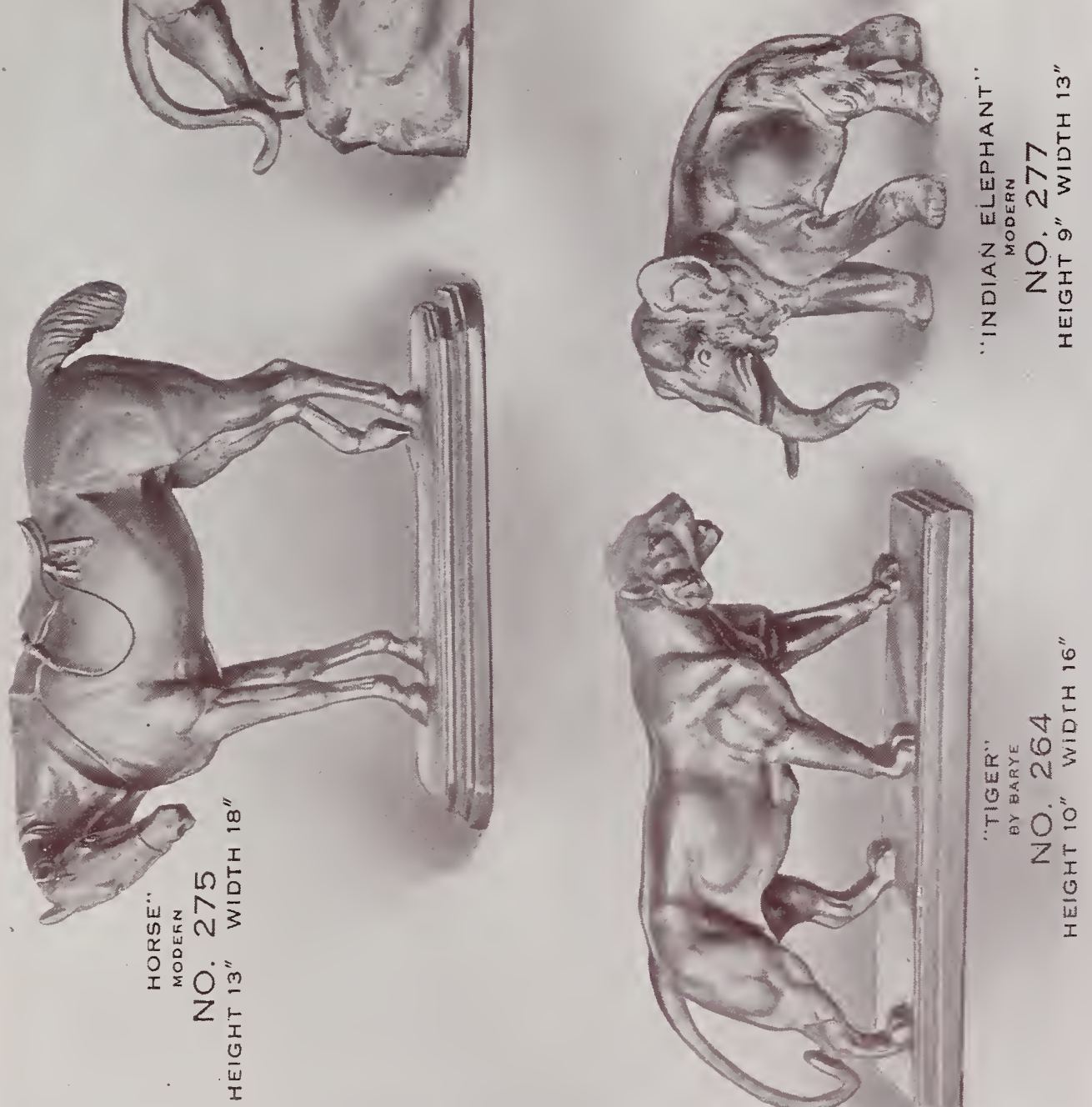

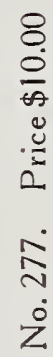

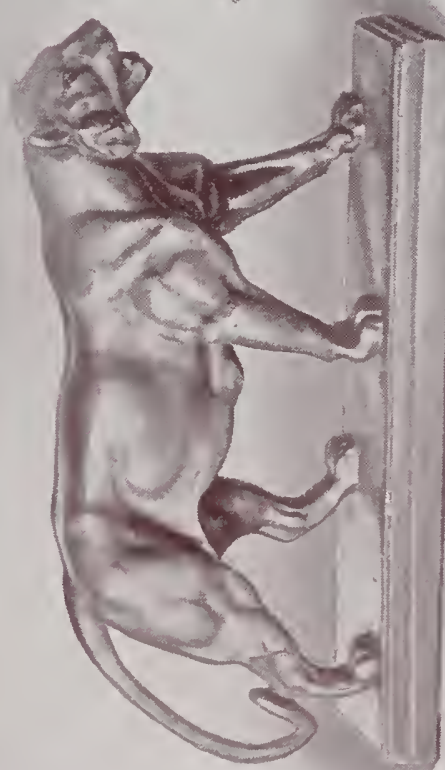

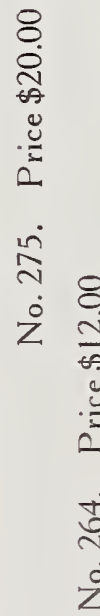

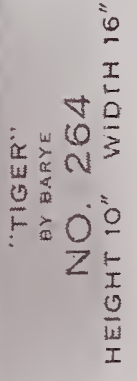



A R M O R

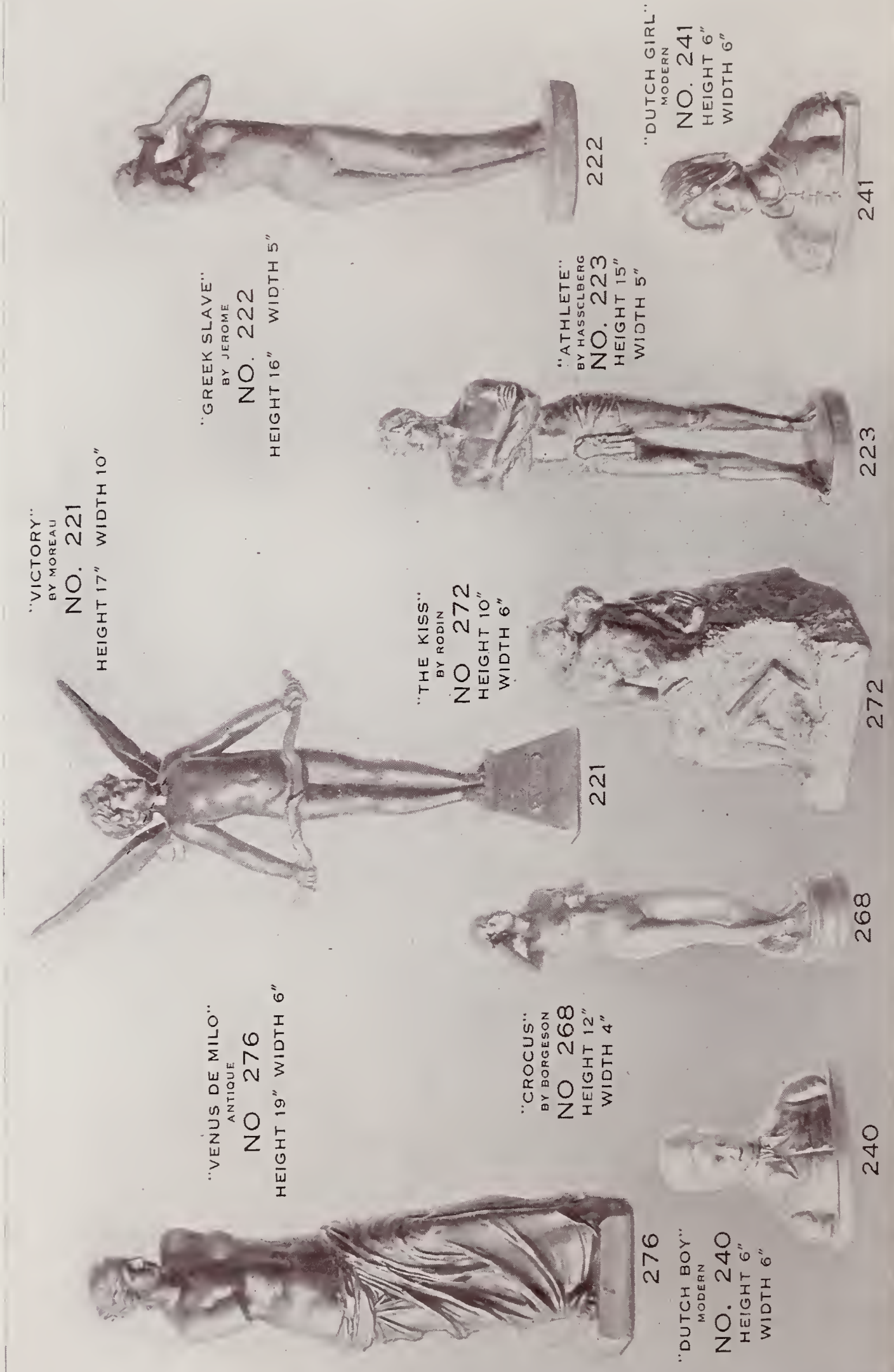
远 $\overline{0}$

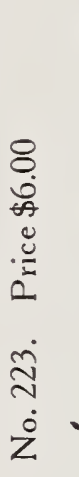


A R M O R

\section{B R O N Z E}
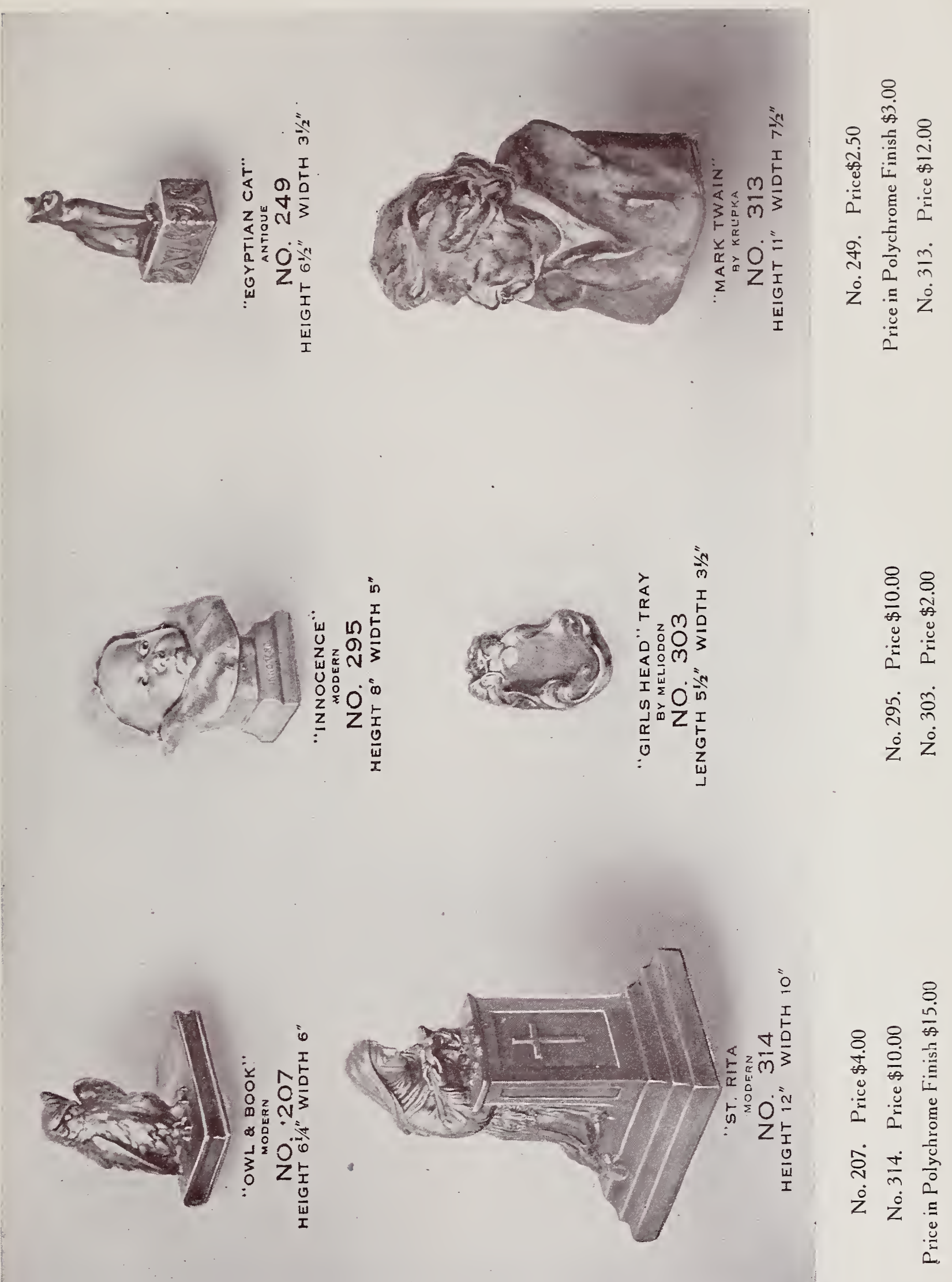

A R M O R
(3)
B R O N Z E

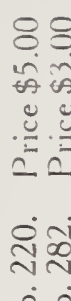

Żं

88

过.

ํํㅇㅇ

żं

8.8

:

ปั่

zंz

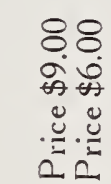

จู호

$88^{\dot{i} z}$
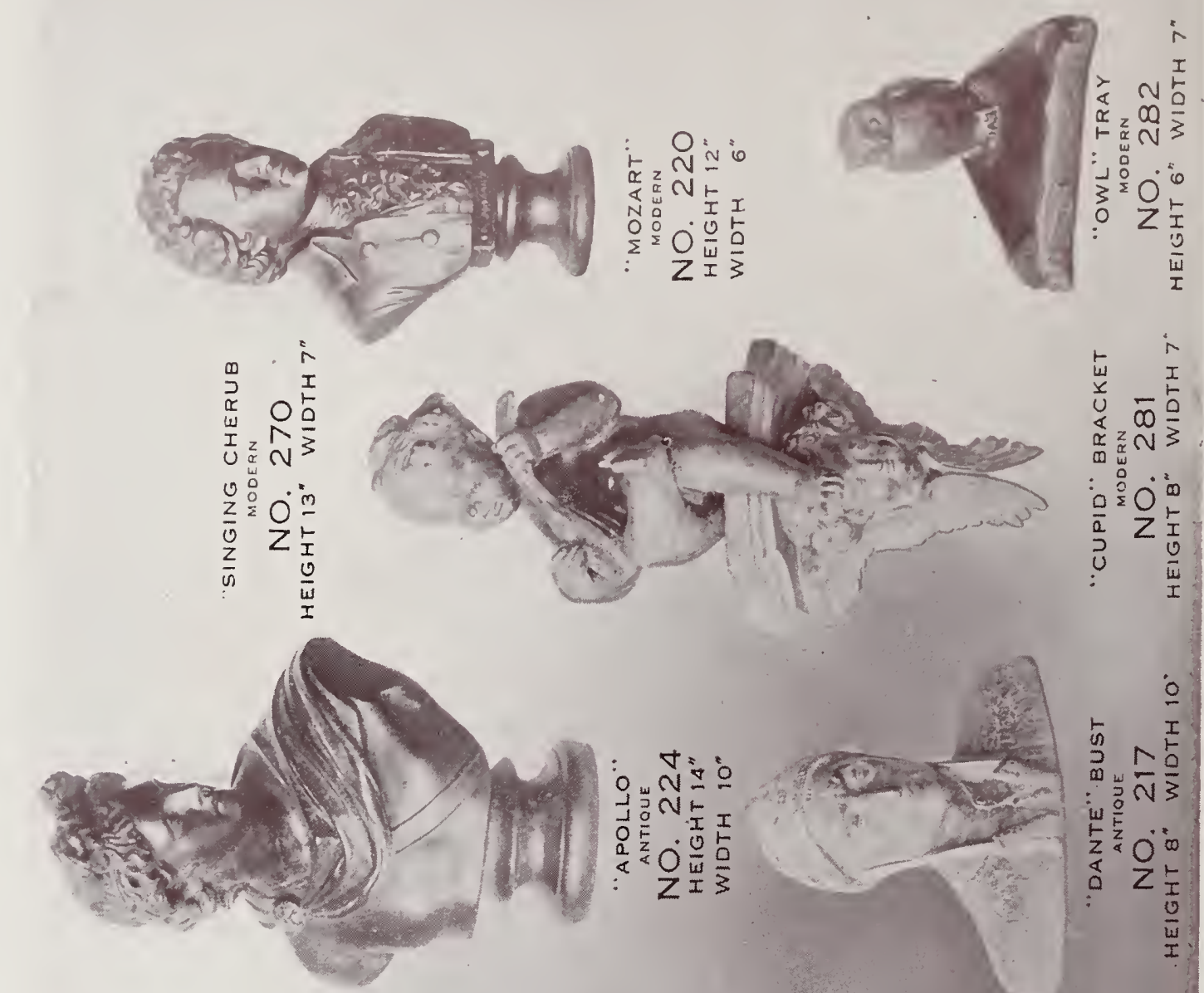

की

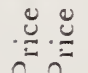

ำ

żं
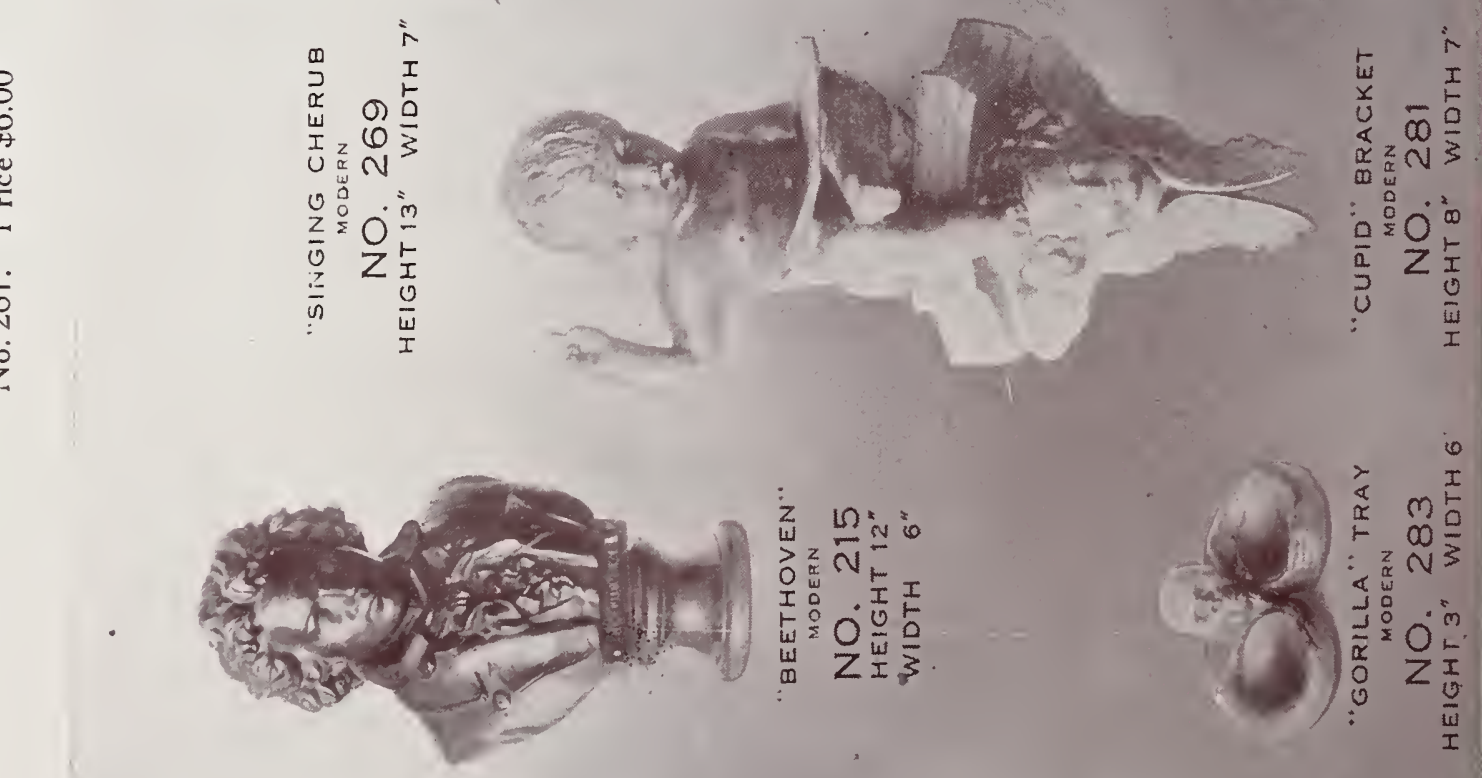


\section{A R M OR B B R E}
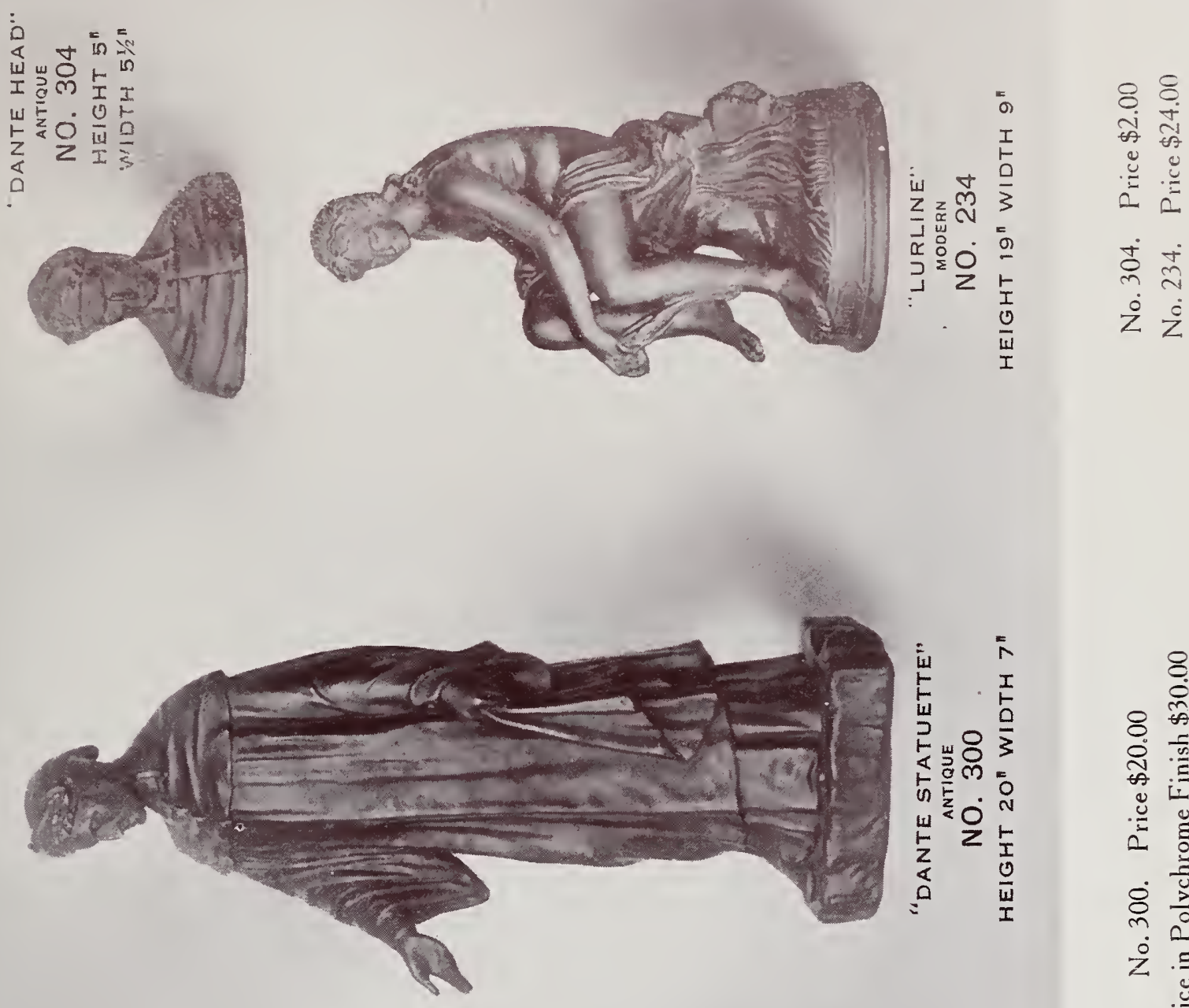

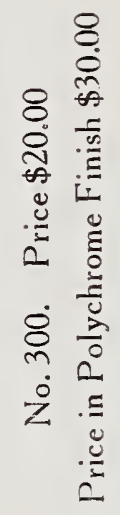

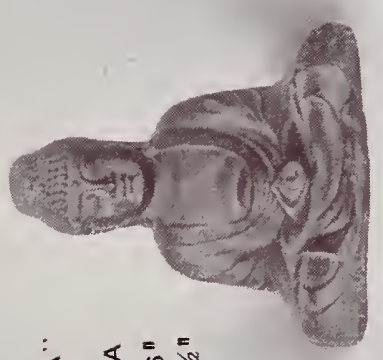

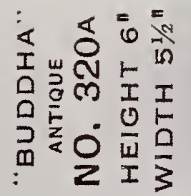

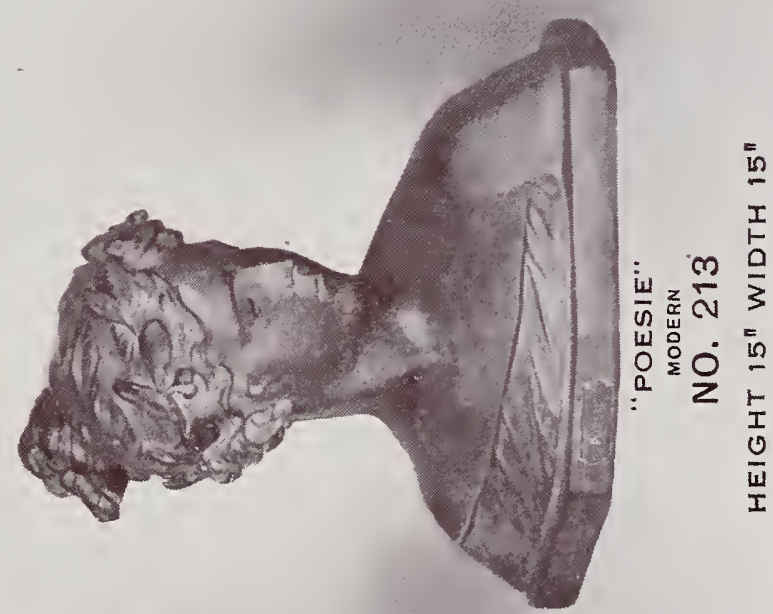

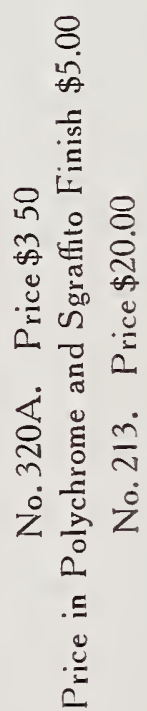

THE NATIONAL METALIZING COMPANY 


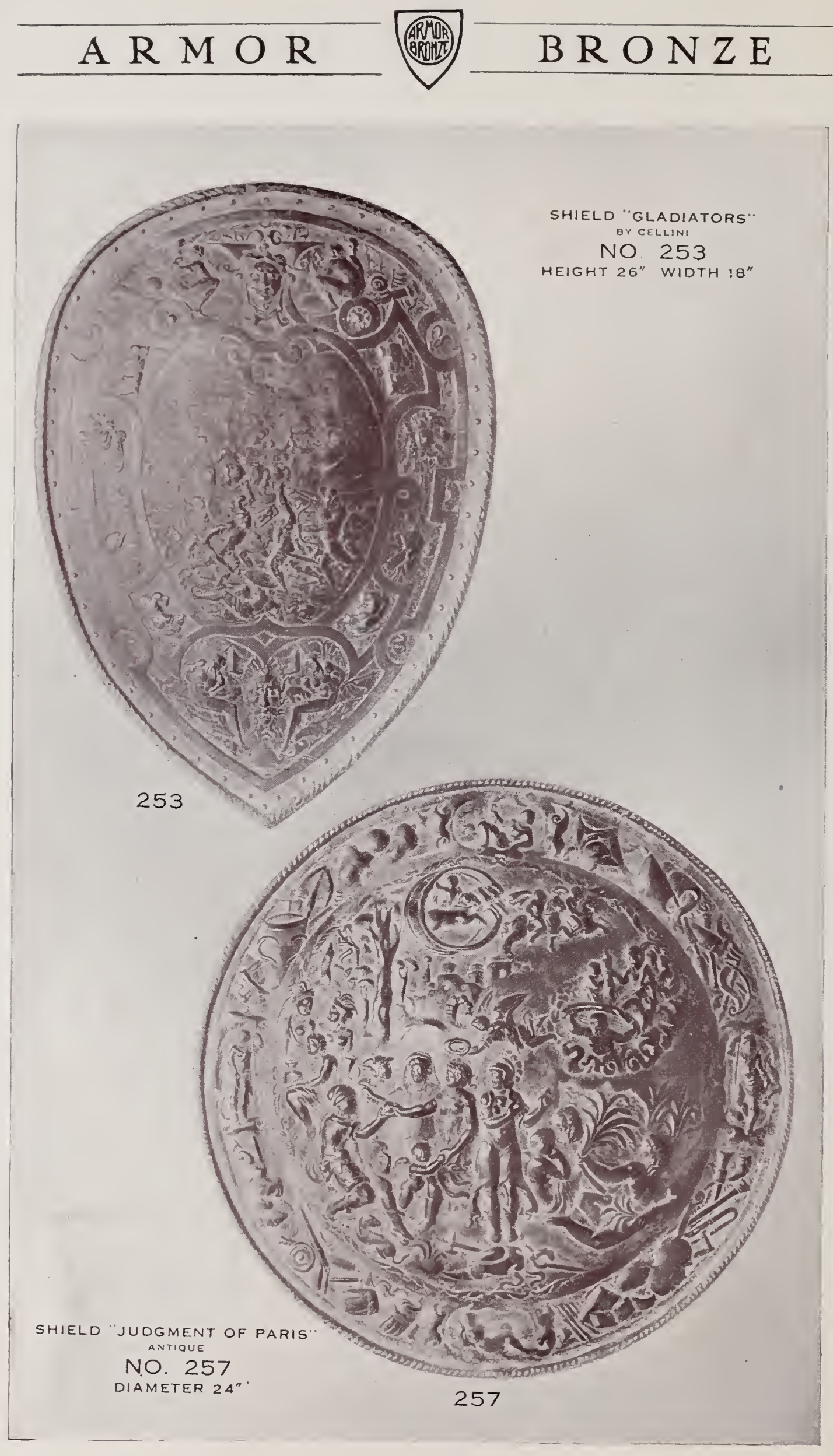

THE NATIONAL METALIZING COMPANY

Page Thirly-four 


\section{A R M O R

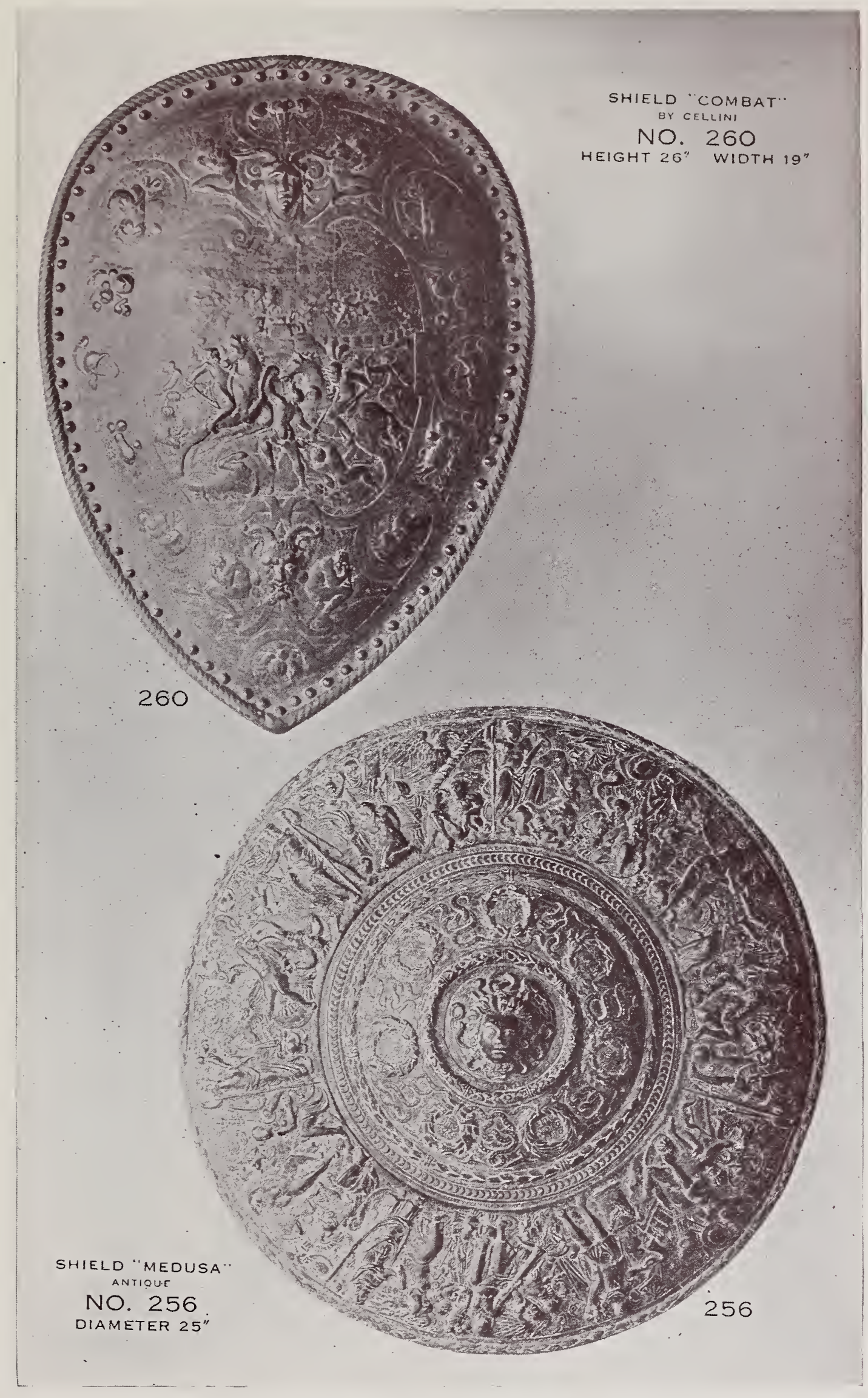

Price $\$ 15.00$

Price $\$ 18.00$ 
Price with Shade $\$ 16.00$

Price without Shade $\$ 12.00$

Price with Shade $\$ 16.00$

Price without Shade $\$ 12.00$

\section{A R M O R}

\section{B R O N Z E}

\section{"SLEEPY CHILDREN"}

NO. 759

ELECTRIC LAMP

SHADE NO. SS/76

TOTAL HEIGHT $17^{\text {" }}$

HEIGHT OF STANDARD $10^{n}$ DIAMETER OF SHADE $10^{\circ}$ DIAMETER OF BASE $6^{\text {" }}$ ONE LIGHT
"OWL AND BOOKS" NO. 762

ELECTRIC LAMP SHADE NO. SS/76 TOTAL HEIGHT $16^{\pi}$ HEIGHT OF STANDARD $9^{\prime \prime}$ DIAMETER OF SHADE $10^{\circ}$ DIAMETER OF BASE $5^{\text {" }}$ ONE LIGHT
NO. 762

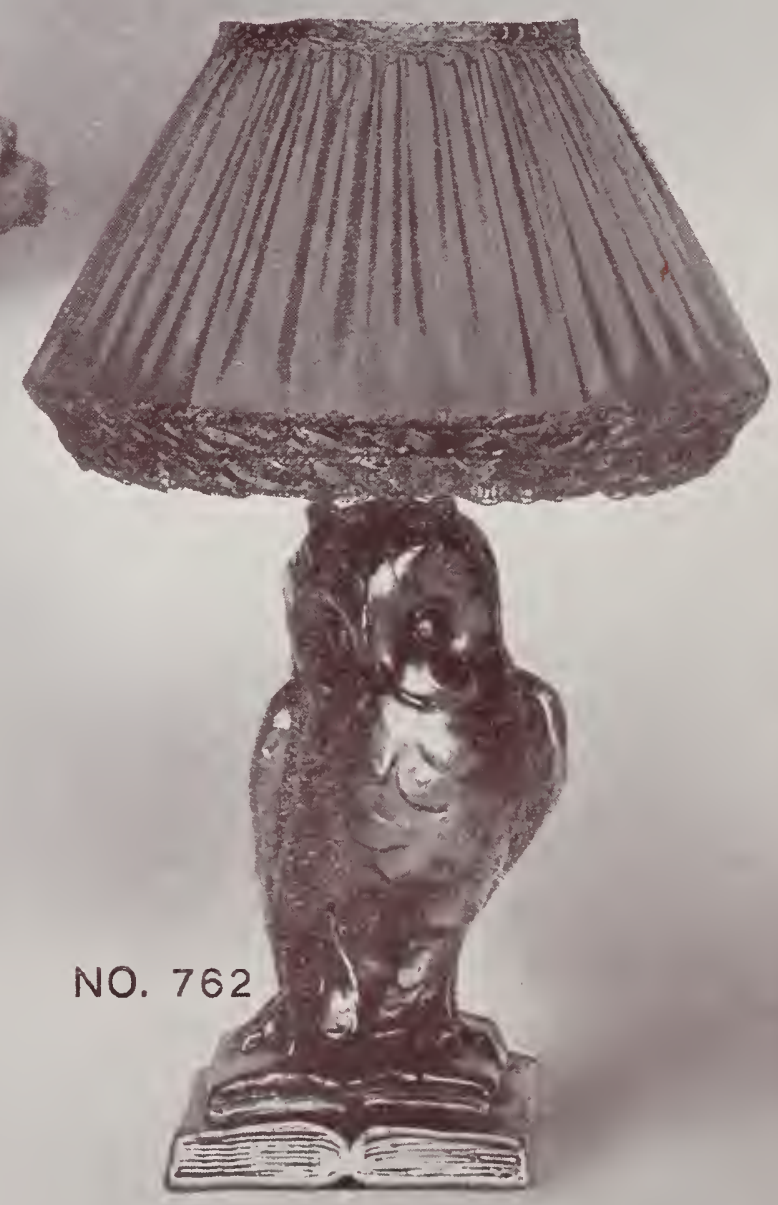



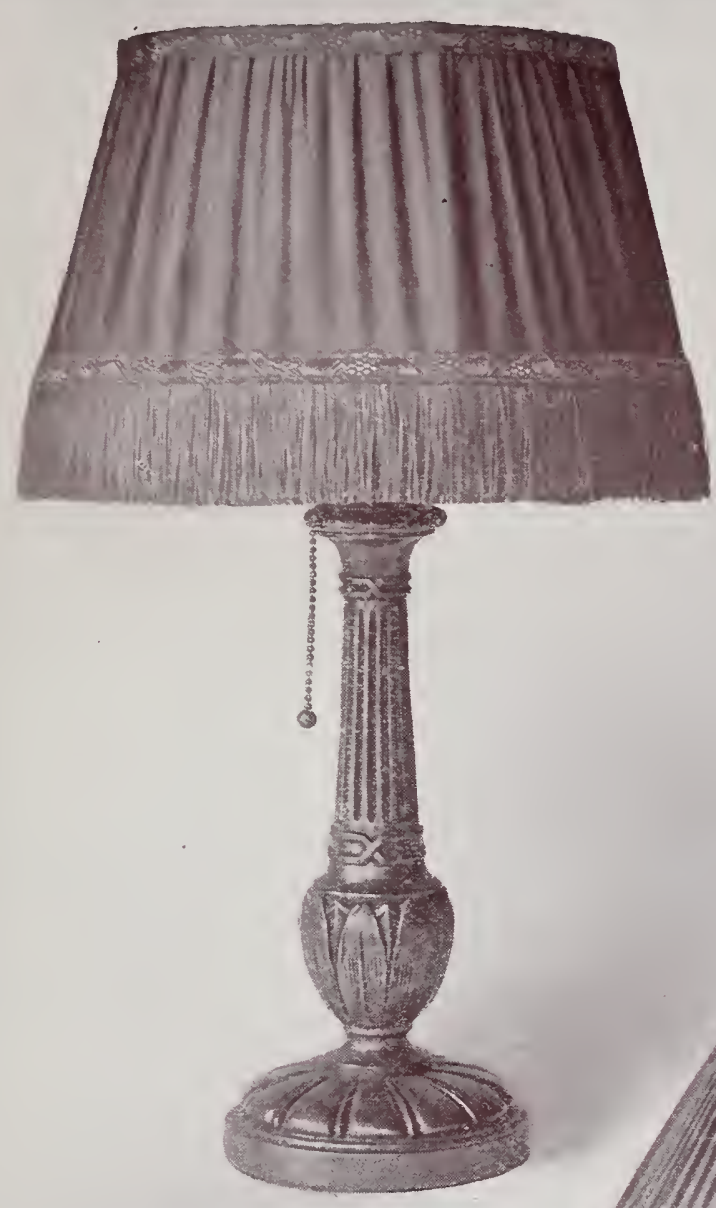

NO. 781

ELECTRIC LAMP

SHADE NO. SS/76

TOTAL HEIGHT 19"

HEIGHT OF STANDARD 11 "

DIAMETER OF SHADE 12"

DIAMETER OF BASE $5^{\prime \prime}$

ONE LIGHT

NO. 780

ELECTRIC LAMP

SHADE NO. SS/23

TOTAL HEIGHT 20"

HEIGH'T OF STANDARD 12"

DIAMETER OF SHADE $12^{\prime \prime}$

DIAMETER OF BASE $5 \frac{1}{2}$ "

ONE LIGHT
Price with

Shade $\$ 14.50$

Price without Shade $\$ 8.00$

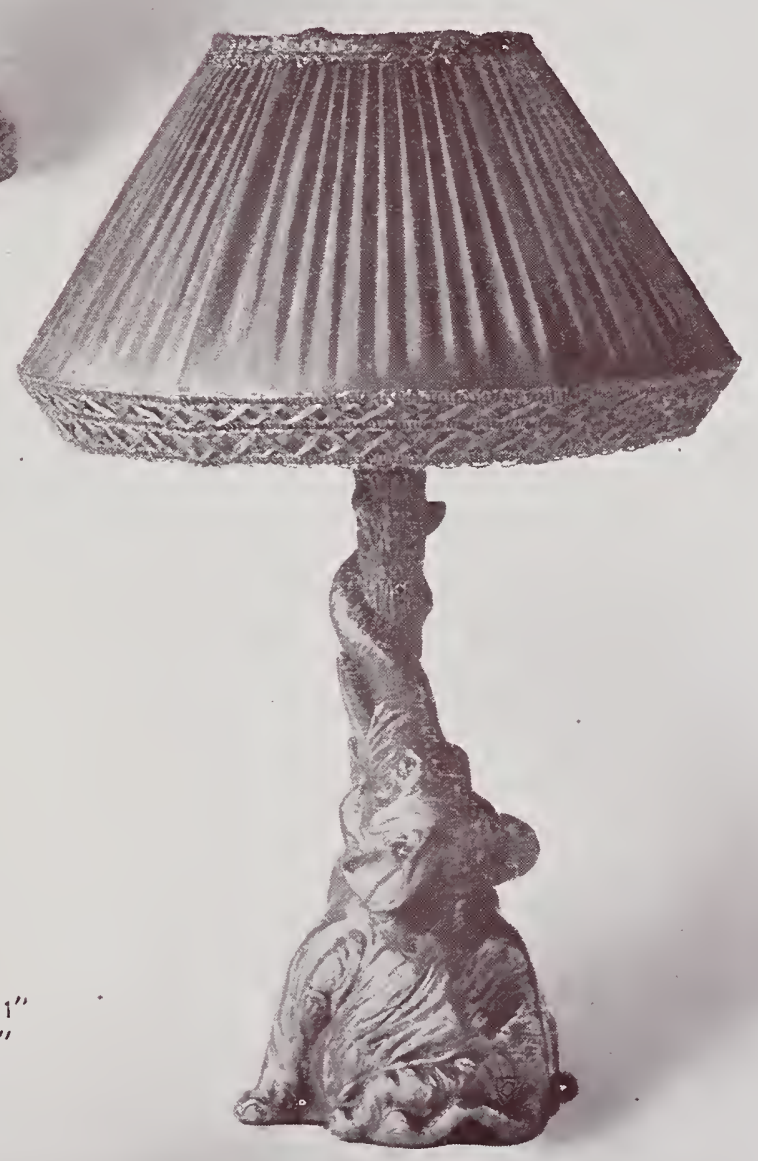

Price with

Shade $\$ 17.00$

Price without Shade $\$ 12.00$

\section{THE NATIONAL METALIZING COMPANY}


Price with

Shade $\$ 14.00$

Price without Shade $\$ 8.00$

Price with

Shade $\$ 14.00$

Price without Shade $\$ 8.00$

\section{A R M O R}

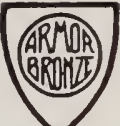

B R O N Z E

NO. 710

ELECTRIC LAMP SHADE NO. SS/24 TOTAL HEIGHT 20" HEIGHT OF STANDARD 12" DIAMETER OF SHADE I4" DIAMETER OF BASE 6 . ONE LIGHT

NO. 709

ELECTRIC LAMP SHADE NO. SS/22 TOTAL. HEIGHT 191/2" HEIGHT OF STANDARD 12" DIAMETER OF SHADE 14" DIAMETER OF BASE $\sigma^{\circ}$ ONE LIGHT

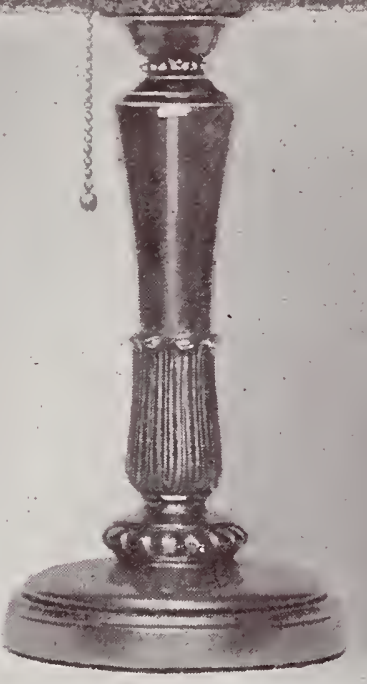

NO. 710

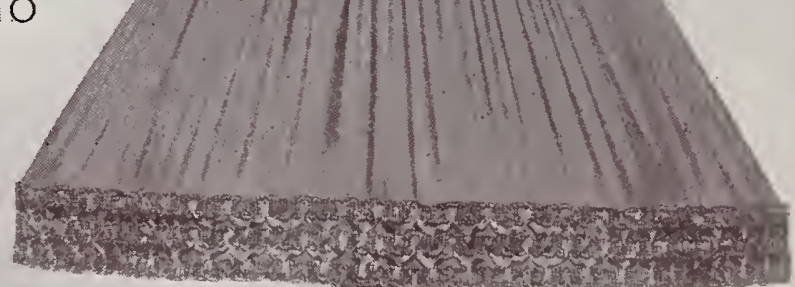

\section{NO. 709}

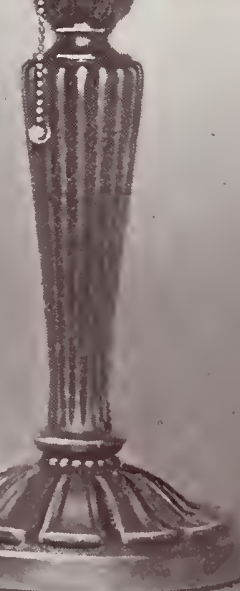




\section{A R M O R}

\section{B R O N Z E}

NO. 711

ELECTRIC LAMP SHADE NO. SS $/ 28$ TOTAL HEIGHT 191/2, HEIGHT OF STANDARD 12 " "DIAMETER OF SHADE 14" DIAMETER OF BASE 6" ONE LIGHT

NO. 713

\section{ELECTRIC LAMP}

SHADE NO. SS/23

TOTAL HEIGHT 20"

HEIGHT OF STANDARD 12" DIAMETER OF SHADE 12"

DIAMETER OF BASE 6"

ONE LIGHT

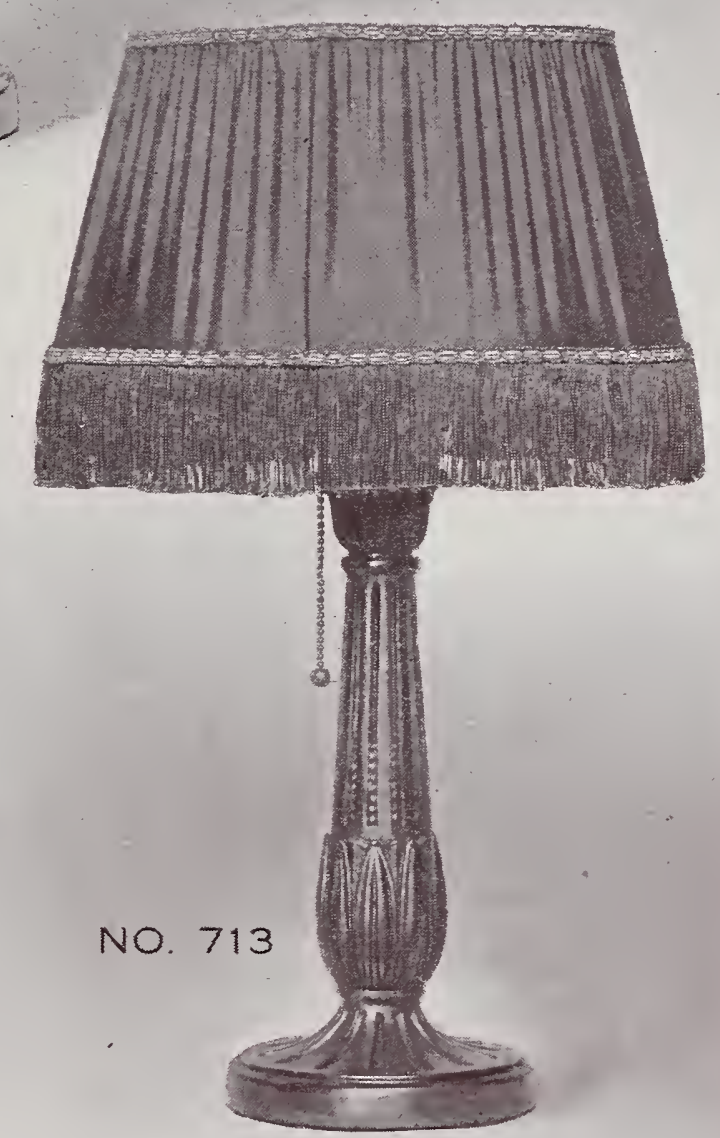

Price with

Shade $\$ 14.50$

Price without Shade $\$ 8.00$

\section{THE NATIONAL METALIZING COMPANY}




\section{A R M O R}

\section{B R O N Z E}

Price with

Shade $\$ 24.00$

Price without Shade $\$ 18.00$

Price with

Shade $\$ 32.00$

Price without

Shade $\$ 20.00$

Price of

Lamp only in Polychrome

Finish, $\$ 25.00$
NO. 782

INK STAND AND ELECTRIC LAMP SHADE NO. SS/85 TOTAL HEIGHT 141/2" HEIGHT OF INK STAND $7 "$ DIAMETER OF SHADE $10^{1 / 2} / \times 5 \frac{1}{1 / 2}$ DIAMETER OF BASE $8^{\prime \prime} \times 6^{\prime \prime}$ ONE LIGHT
NO. 768

ELECTRIC LAMP SHADE NO. SS/80 TOTAL HEIGHT $23^{\prime \prime}$ HEIGHT OF STANDARD 13 DIAMETER OF SHADE $14^{\prime \prime}$ DIAMETER OF BASE $8^{\prime \prime}$ TWO LIGHTS
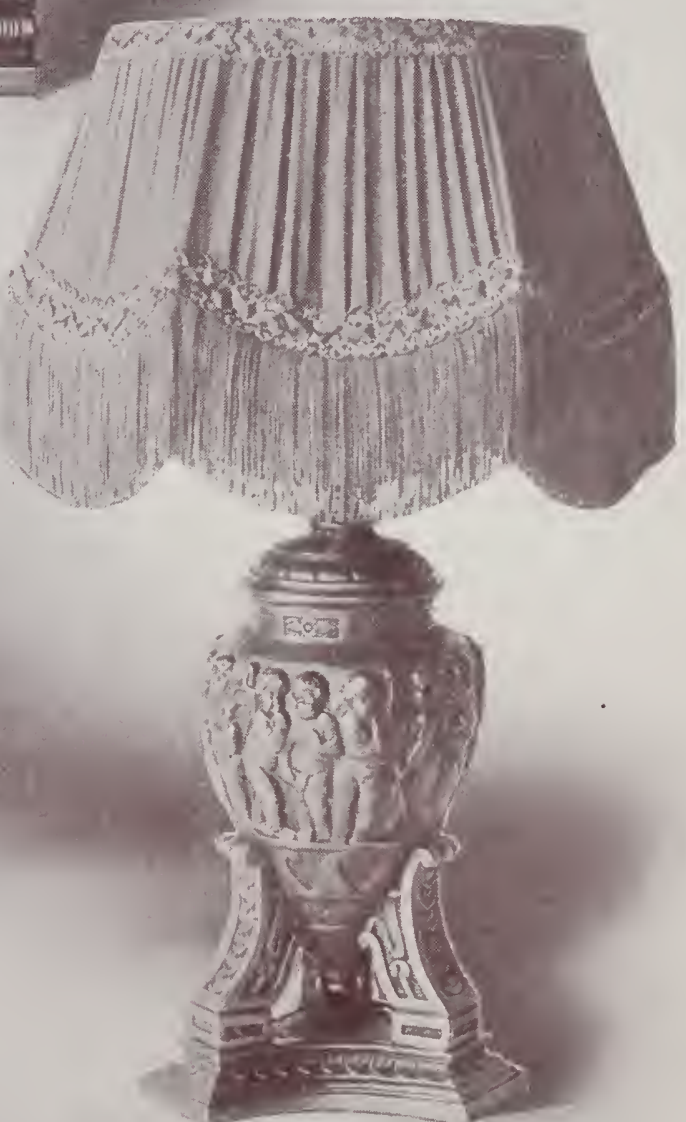


\section{A R M O R}

\section{B R O N Z E}

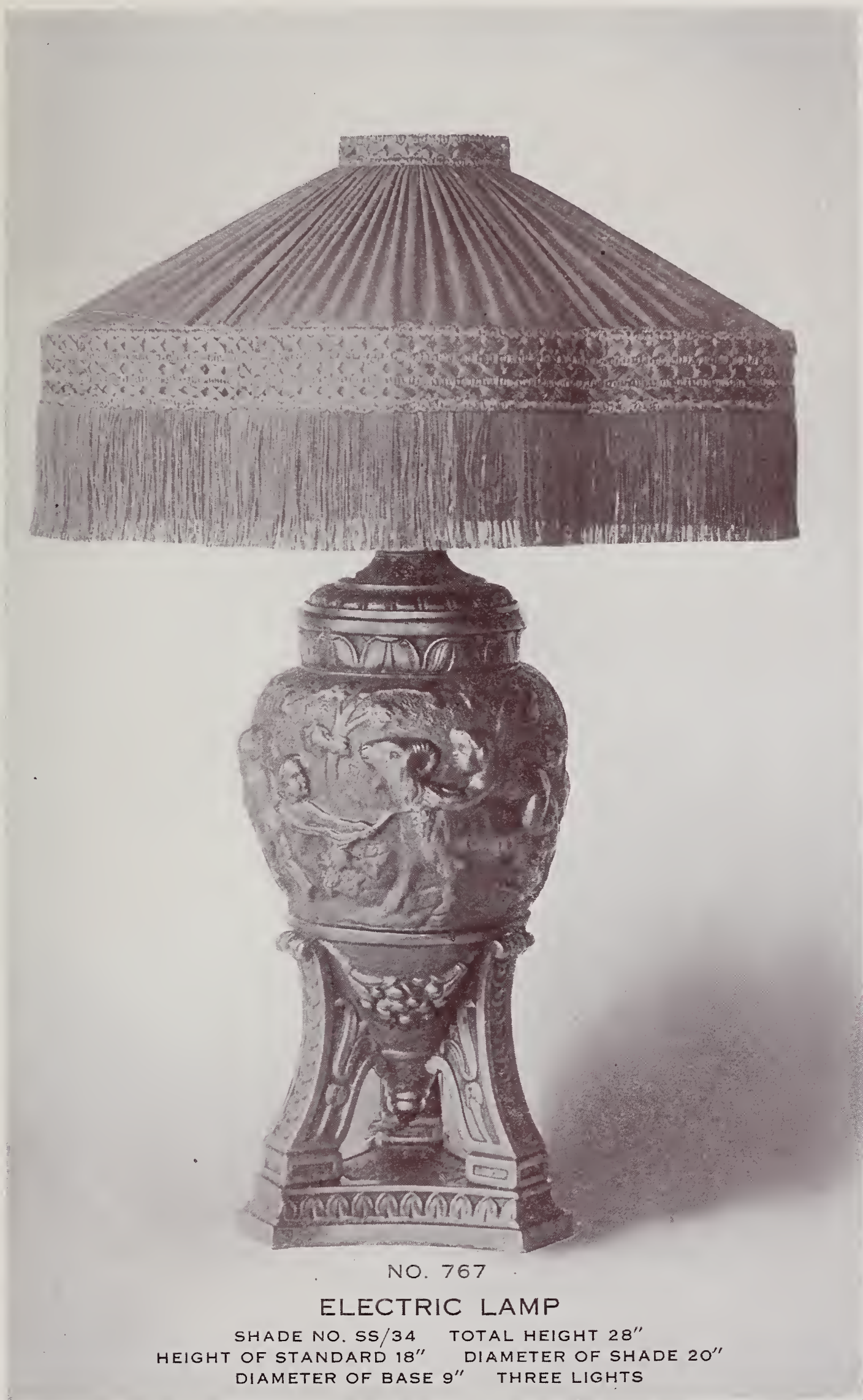

Price with

Shade $\$ 53.00$

Price without Shade $\$ 36.00$

Price of

Lamp only in Polychrome Finish, \$44.00 


\section{A R M O R}

\section{B R O N Z E}

Price with

Shade $\$ 53.00$

Price without Shade $\$ 36.00$

Price of

Lamp only

in Polychrome

Finish, $\$ 44.00$

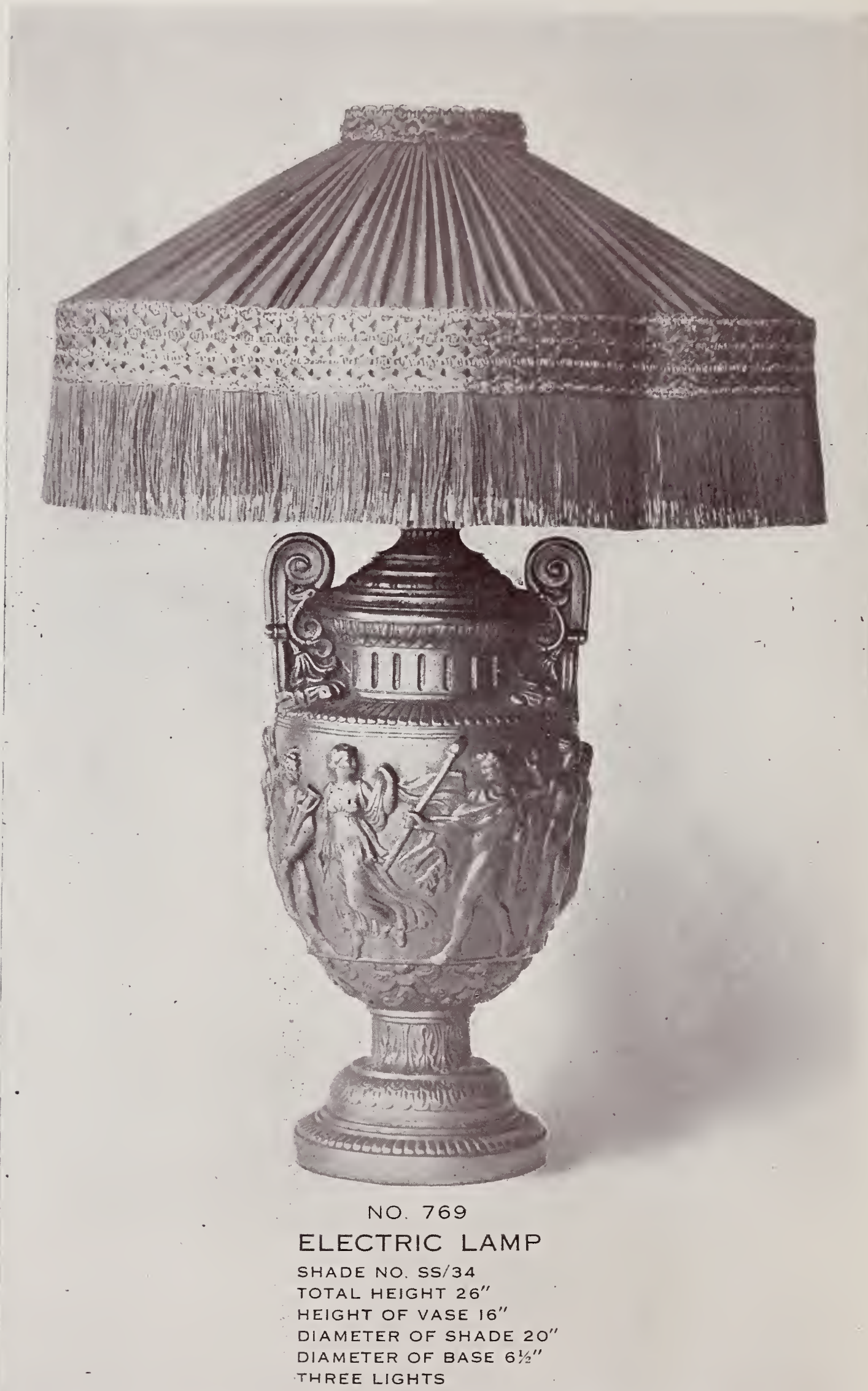

THE NATIONAL METALIZING COMPANY Page Forly-lwo 
A R M O R

B R O N Z E

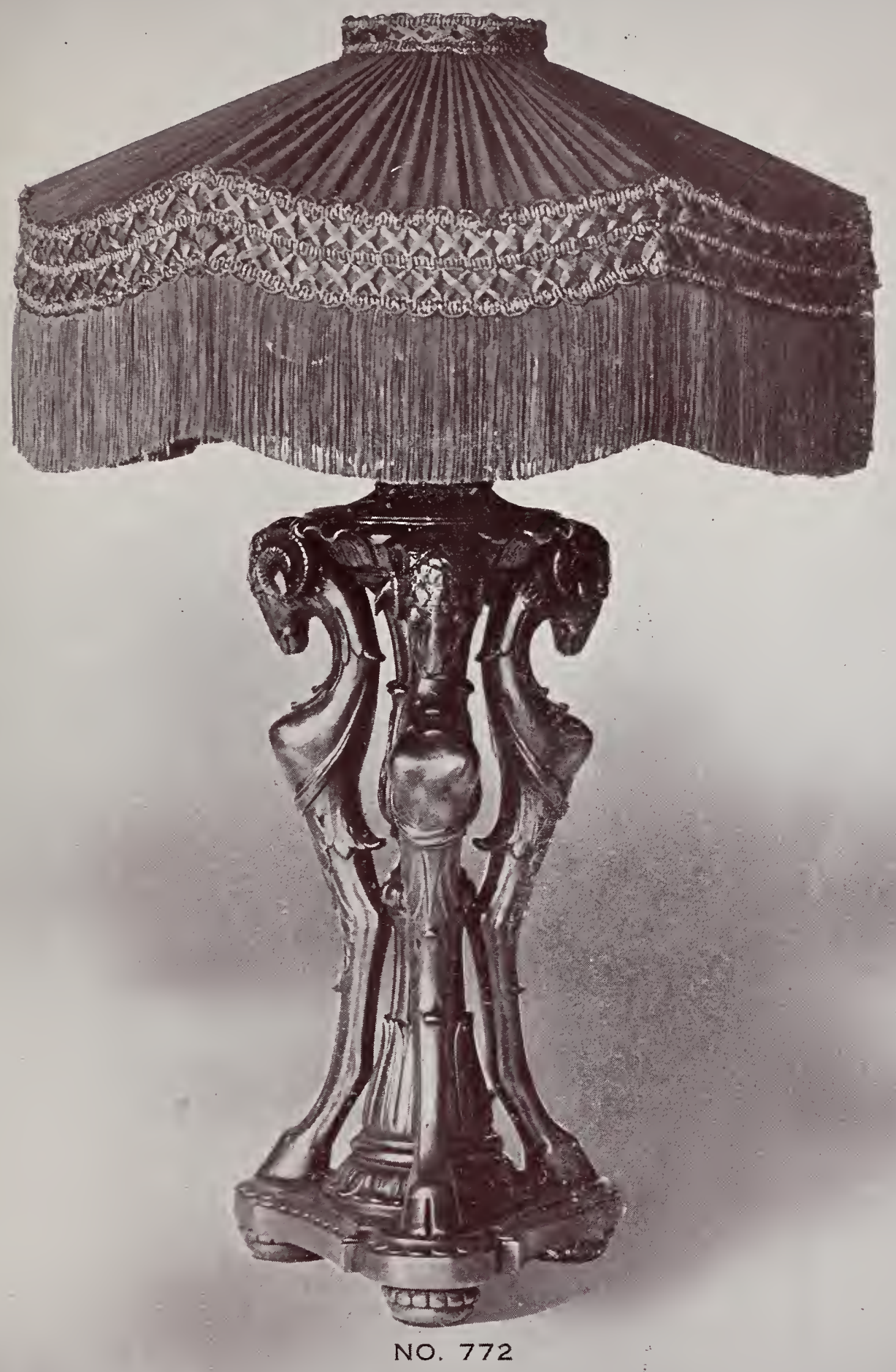

Price with

Shade $\$ 45.00$

Price without

Shade $\$ 30.00$

Price of

Lamp only

in Polychrome

Finish, $\$ 35.00$

ELECTRIC LAMP

SHADE NO. $55 / 79$. TOTAL HEIGHT 28"

HEIGHT OF STANDARD $18^{\prime \prime}$ DIAMETER OF SHADE $18^{\prime \prime}$.

DIAMETER OF BASE 8 I $/ 2 "$ THREE LIGHTS 


\section{A R M O R}

\section{B R O N Z E}

Price with

Shade $\$ 35.00$

Price without Shade $\$ 20.00$

Price of

Lamp only in Polychrome and Sgraffito Finish, $\$ 25.00$

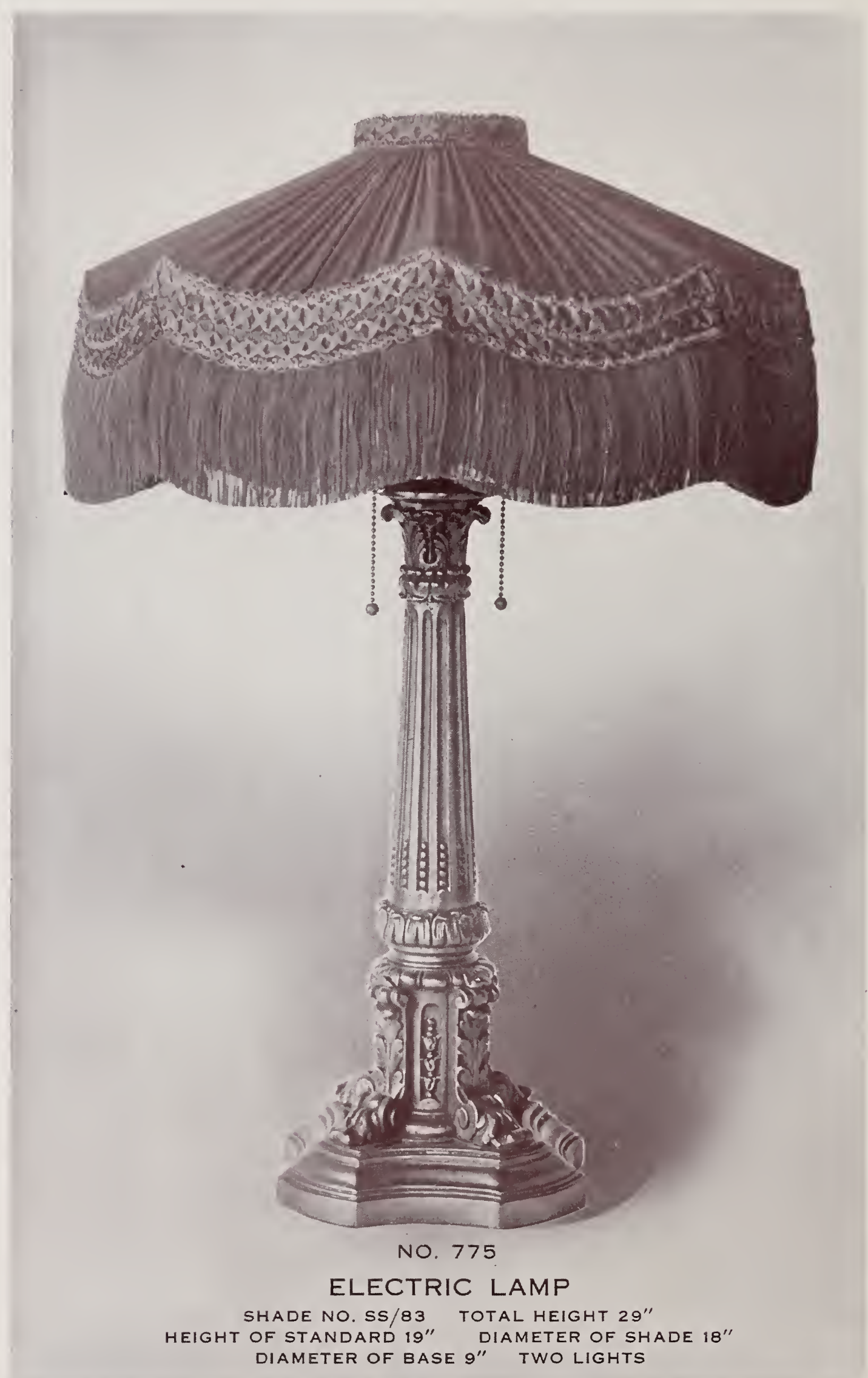

THE NATIONAL METALIZING COMPANY 


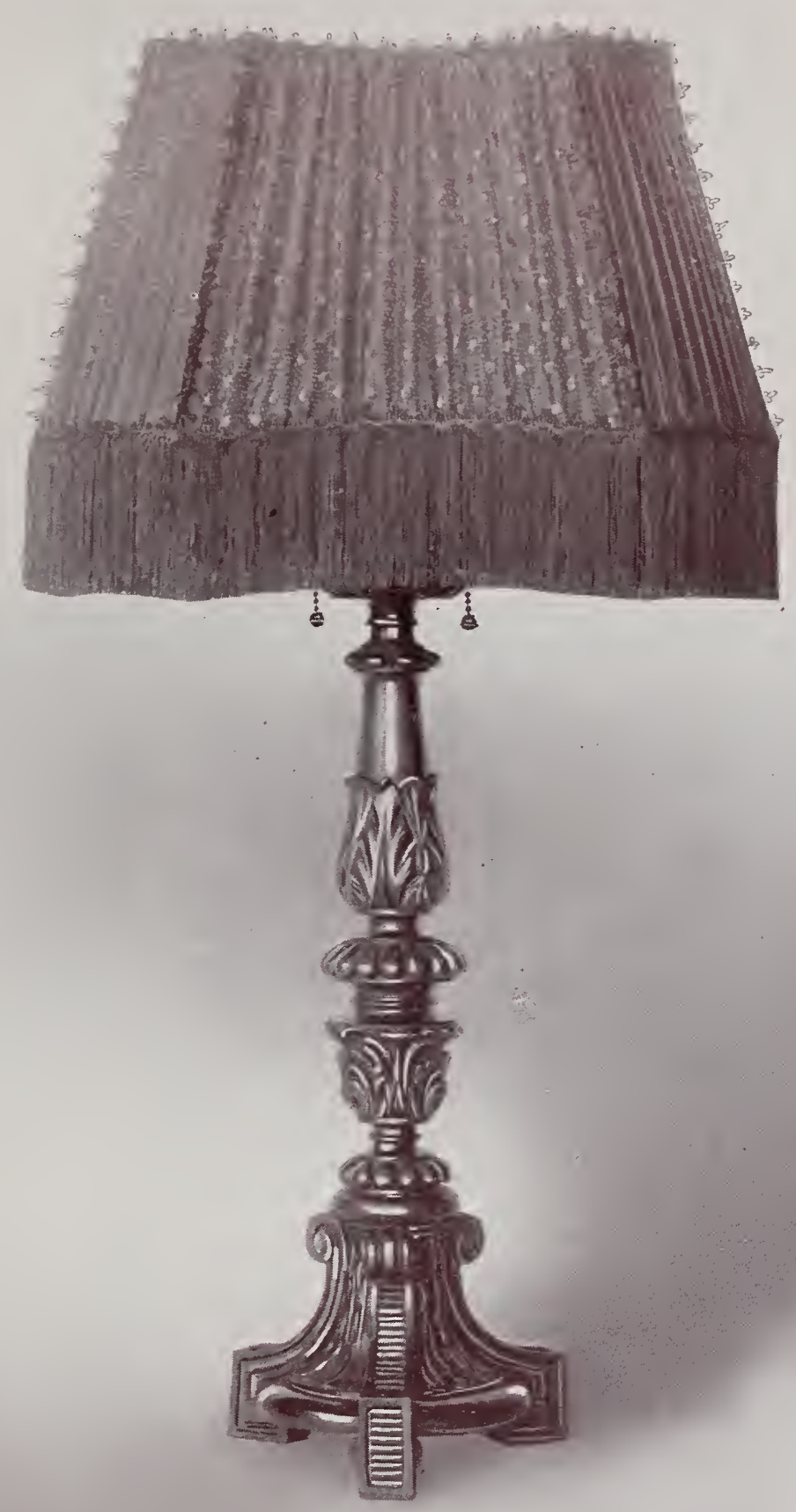

Price with

Shade $\$ 46.00$

Price without

Shade $\$ 24.00$

Price of

Lamp only

in Polychrome

Finish, $\$ 28.00$

\section{THE NATIONAL METALIZING COMPANY}




\section{A R M O R}

Price with Shade $\$ 40.00$

Price without Shade $\$ 24.00$

Price of Lamp only in Polychrome Finish, $\$ 30.00$

Price with Shade $\$ 26.00$

Price without Shade $\$ 16.00$

Price of

Lamp only in Polychrome Finish, \$20.00
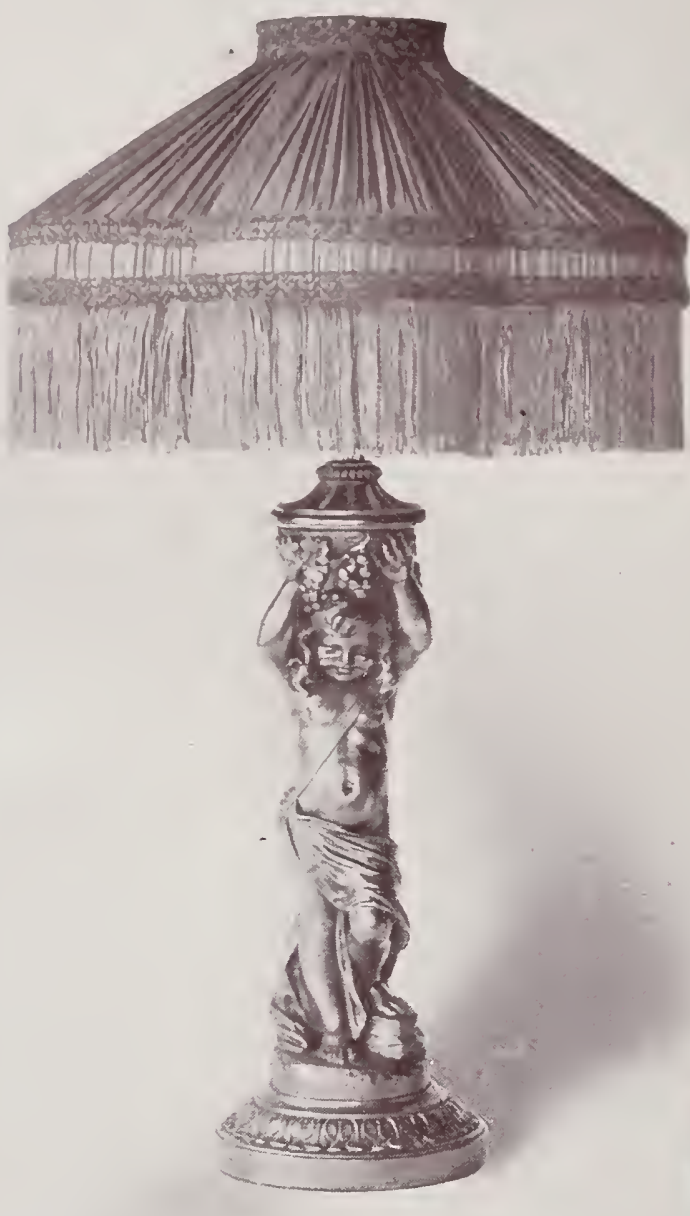

NO. 784

EGYPTIAN" ELECTRIC LAMP

SHADE NO $5 S / 106$

TOTAL HEIGHT $2 i^{\prime \prime}$

HEIGHT OF STANDARO $12 \%$

DIAMETER OF SHADE 2

WIDTH OF PASE 6"

TWO LIGHTS
ELECTRIC LAMP

SHADE NO. SS/34B TOTAL HEIGHT $271 / 2$ " HEIGHT OF STANDARD $181 / 2 "$ DIAMETER OF SHADE $18^{\prime \prime}$ DIAMETER OF BASE 7" TWO LIGHTS

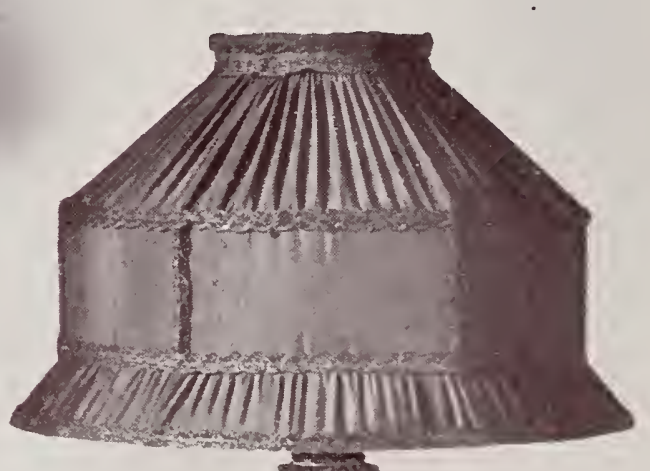

THE NATIONAL METALIZING COMPANY 


\section{A R M O R}

\section{B R O N Z E}

NO. 771

"BUDDHA"

ELECTRIC LAMP

SHADE NO. SS/77

TOTAL HEIGHT 24"

HEIGHT OF BUDDHA $13^{\prime \prime}$

DIAMETER OF SHADE $16^{\prime \prime}$ DIAMETER OF BASE 10"

TWO LIGHTS

NO. 770

"CHINESE DOG" ELECTRIC LAMP

SHADE NO. SS/78 TOTAL HEIGHT 18" HEIGHT OF DOG $10^{\prime \prime}$ DIAMETER OF SHADE 14" DIAMETER OF BASE $9^{\prime \prime}$ TWO LIGHTS
Price with

Shade $\$ 40.00$

Price without

Shade $\$ 22.00$

Price of

Lamp only

in Polychrome

and Sgraffito

Finish, $\$ 30.00$

See color sheet at front of book for color of silk shade and color effect of Polychrome and Sgraffito.

Price with Shade $\$ 29.00$

Price without Shade $\$ 18.00$

See shade of "Buddha" Lamp on color plate for color of this shade. 


\section{A R M O R}

Price with Shade $\$ 44.00$

Price without Shade $\$ 24.00$

Price of

Lamp only in Polychrome and Sgraffito Finish, $\$ 30.00$

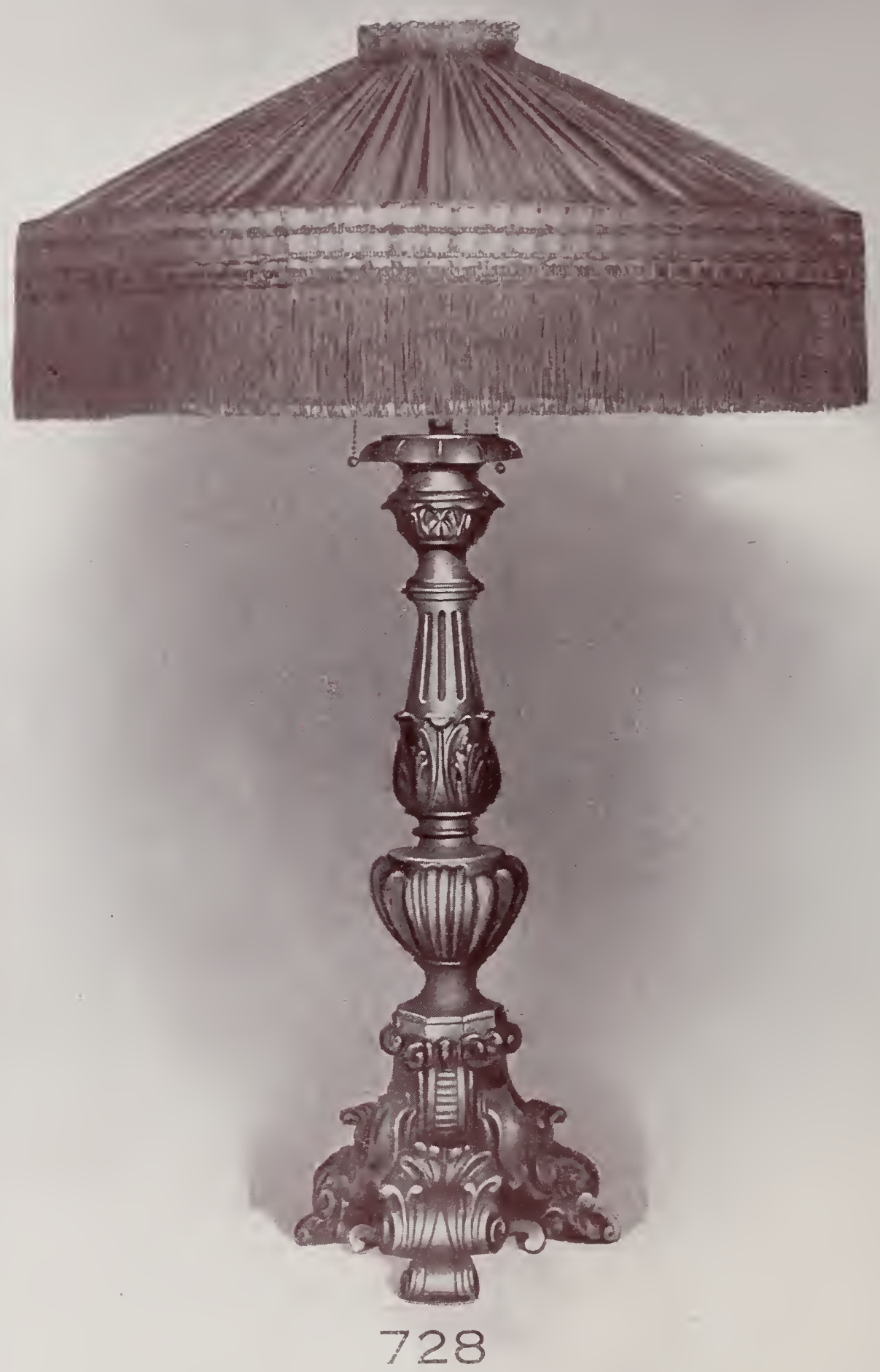

ELECTRIC LAMP NO. 728

SHADE NO. SS/28 TOTAL HEIGHT $34^{\prime \prime}$ DIAMETER OF SHADE 22 HEIGHT OF STANDARD $22 "$ DIAMETER OF BASE 9 " 
A R M O R

B R O N Z E
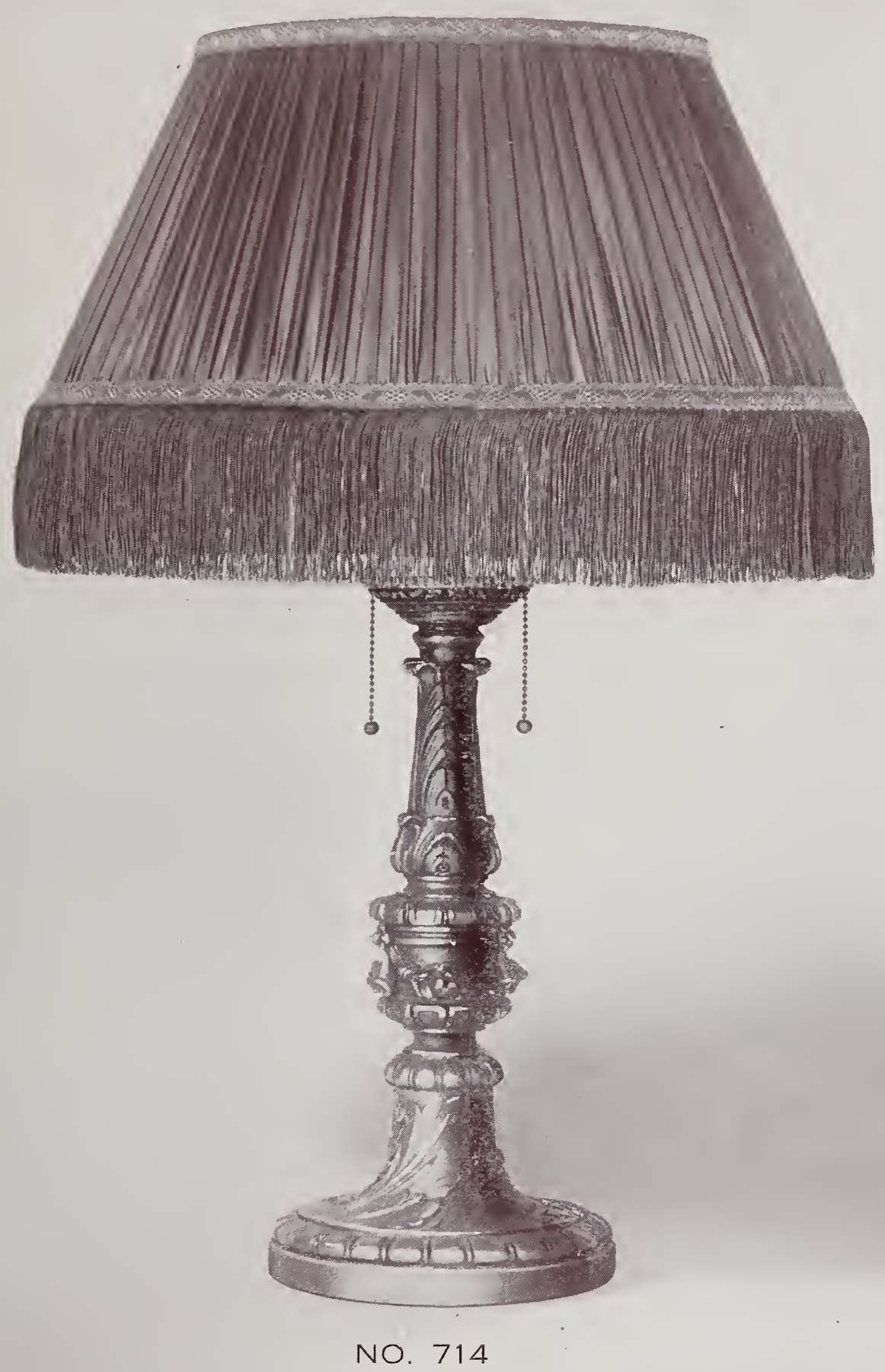

Price with

Shade $\$ 32.00$

Price without

Shade $\$ 18.00$

ELECTRIC LAMP

SHADE NO. SS/26 TOTAL.HEIGHT $27 \% 2^{\prime \prime}$

HEIGHT OF STANDARD 16" DIAMETER OF SHADE $18^{\prime \prime}$

DIAMETER OF BASE $71 / 2^{\prime \prime}$ TWO LIGHTS 
Price with

Shade $\$ 25.00$

Price without Shade $\$ 14.00$

Price of Lamp only in Polychrome Finish, $\$ 18.00$

Price with Shade $\$ 28.00$

Price without Shade $\$ 13.00$

\section{A R M O R}

\section{B R O N Z E}

NO. 779

ELECTRIC LAMP

SHADE NO. SS/84

TOTAL HEIGHT $251 \frac{1}{2 \prime \prime}$ HEIGHT OF STANDARD 151/2"

DIAMETER OF SHADE $18^{\prime \prime}$ DIAMETER OF BASE 71/2" TWO LIGHTS
NO. 773

ELECTRIC LAMP

SHADE NO. SS/79

TOTAL HEIGHT $25^{\prime \prime}$

HEIGHT OF STANDARD $15^{\prime \prime}$ DIAMETER OF SHADE $18^{\prime \prime}$ DIAMETER OF BASE $71 / 2^{\prime \prime}$ TWO LIGHTS

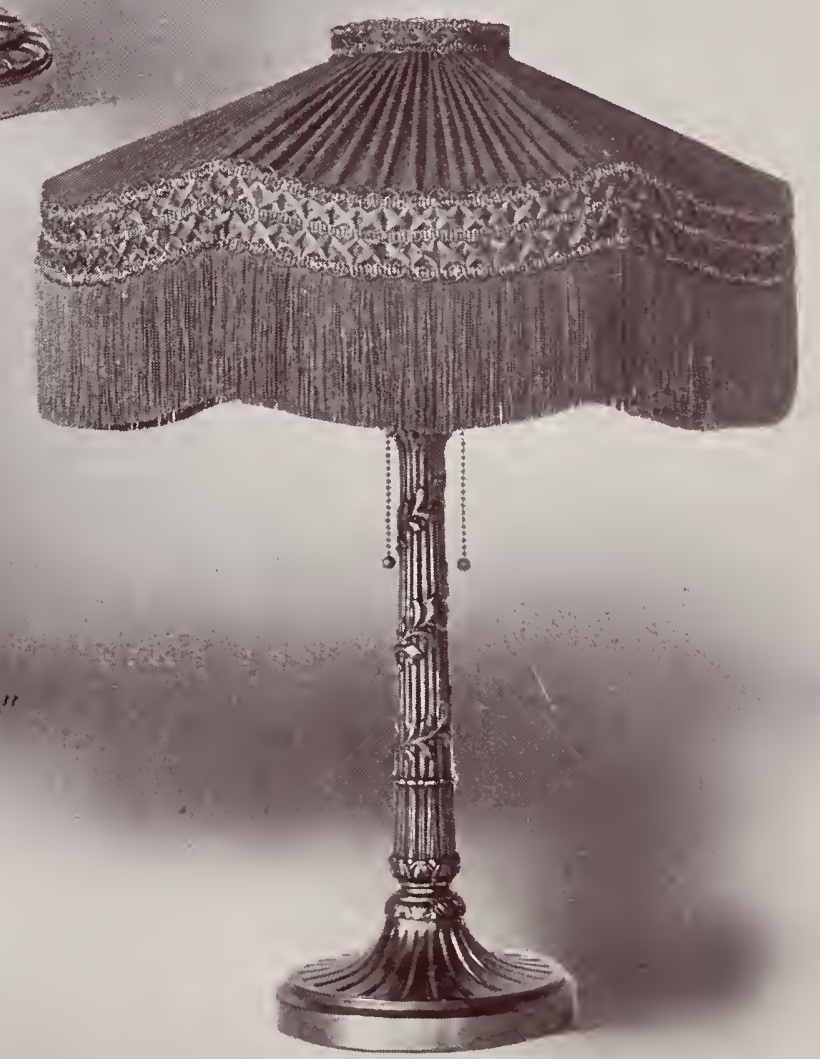




\section{A R M O R}

NO. 776

ELECTRIC LAMP

SHADE NO. SS/79

TOTAL HEIGHT 251/2"

HEIGHT OF STANDARD 151/2"

DIAMETER OF SHADE $18^{\prime \prime}$

DIAMETER OF .BASE 7 $\mathrm{K}^{\prime \prime} \mathrm{2}^{\prime \prime}$

TWO LIGHTS

NO. 777

ELECTRIC LAMP

SHADE NO. SS $\% 80$

TOTAL HEIGHT $25^{\prime \prime}$

HEIGHT OF STANDARD 15"

DIAMETER OF SHADE $14^{\prime \prime}$

DIAMETER OF BASE $7^{\prime \prime}$

TWOULIGHTS
Price with

Shade $\$ 29.00$

Price without Shade $\$ 14.00$

Price of

Lamp only in Polychrome and Sgraffito

Finish, $\$ 20.00$

Price with

Shade $\$ 24.00$

Price without Shade $\$ 12.00$ 
A R M O R

$\mathrm{B} \mathrm{R} O \mathrm{NZE}$

Price with

Shade $\$ 44.00$

Price without Shade $\$ 24.00$

Price of

Lamp only

in Polychrome

Finish, $\$ 28.00$
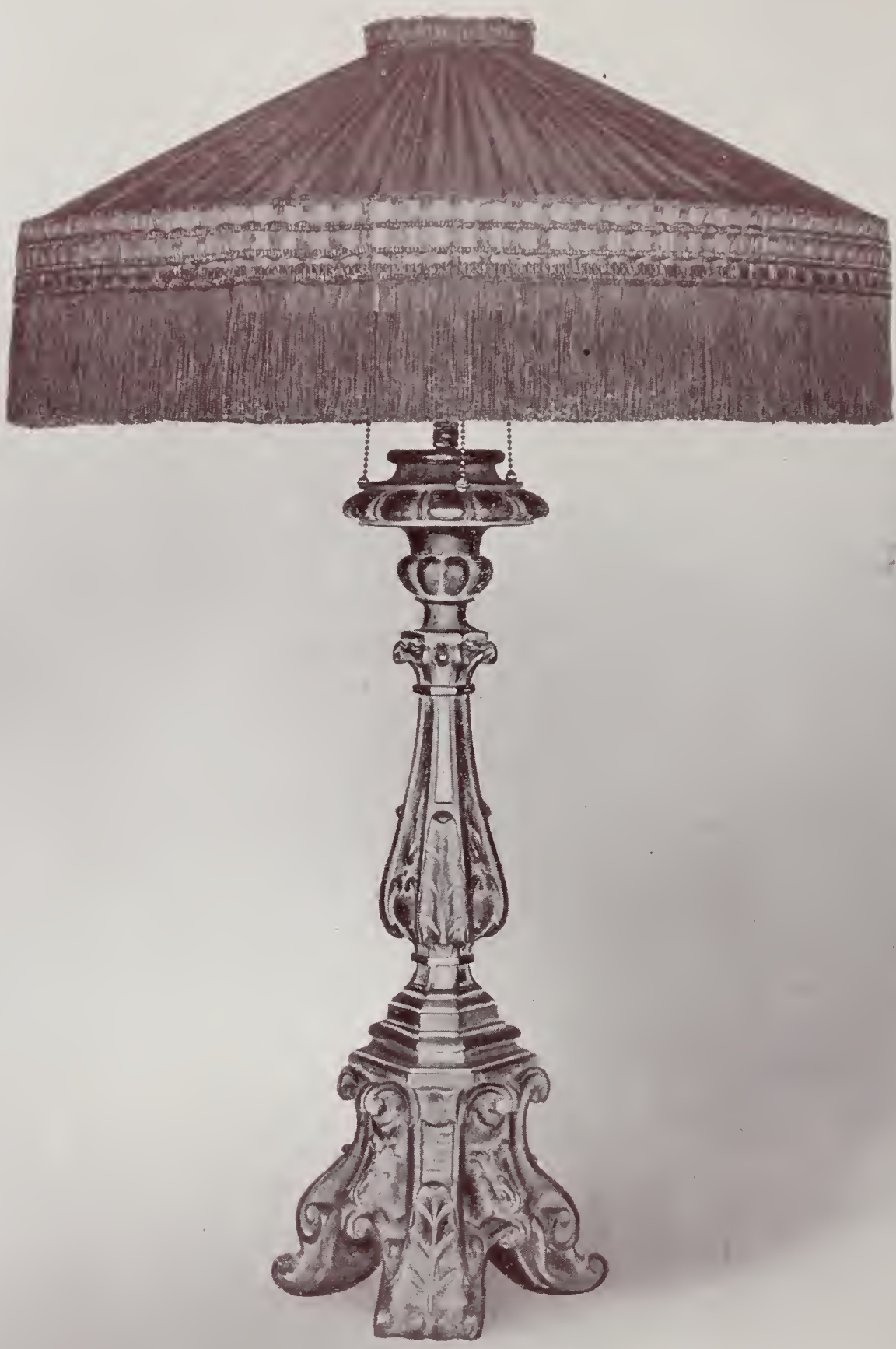

NO. 727

ELECTRIC LAMP

SHADE NO. SS/28 TOTAL HEIGHT $34^{*}$

HEIGHT OF STANDARD 22" DIAMETER OF SHADE $22^{\prime \prime}$

DIAMETER OF BASE 9" THREE LIGHTS 


\section{A R M O R}
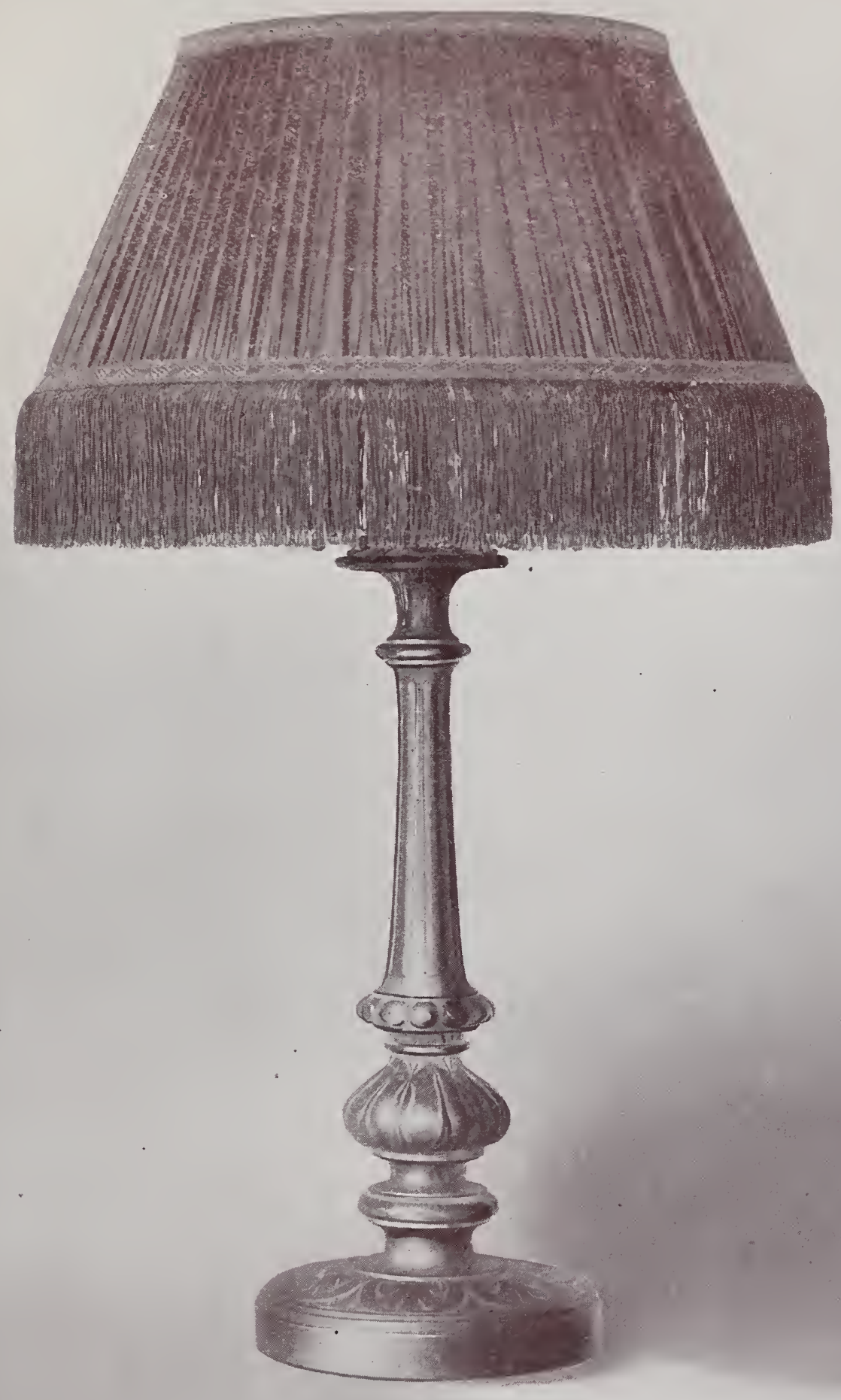

NO. 716

ELECTRIC LAMP

SHADE NO. SS/26, TOTAL HEIGHT 3.

HEIGHT OF STANDARD 191/2" DIAMETER OF SHADE 18*

DIAMETER OF BASE $8^{\prime \prime}$ TWO LIGHTS

Price with

Shade $\$ 30.00$

Price without Shade $\$ 16.00$

Price of

Lamp only in Polychrome

Finish, $\$ 20.00$ 
A R M O R

Price with Shade $\$ 24.00$

\section{Price without} Shade $\$ 13.00$

Price with Shade $\$ 24.00$

Price without Shade $\$ 14.00$

\section{Price of}

Lamp only

in Polychrome

Finish, $\$ 18.00$

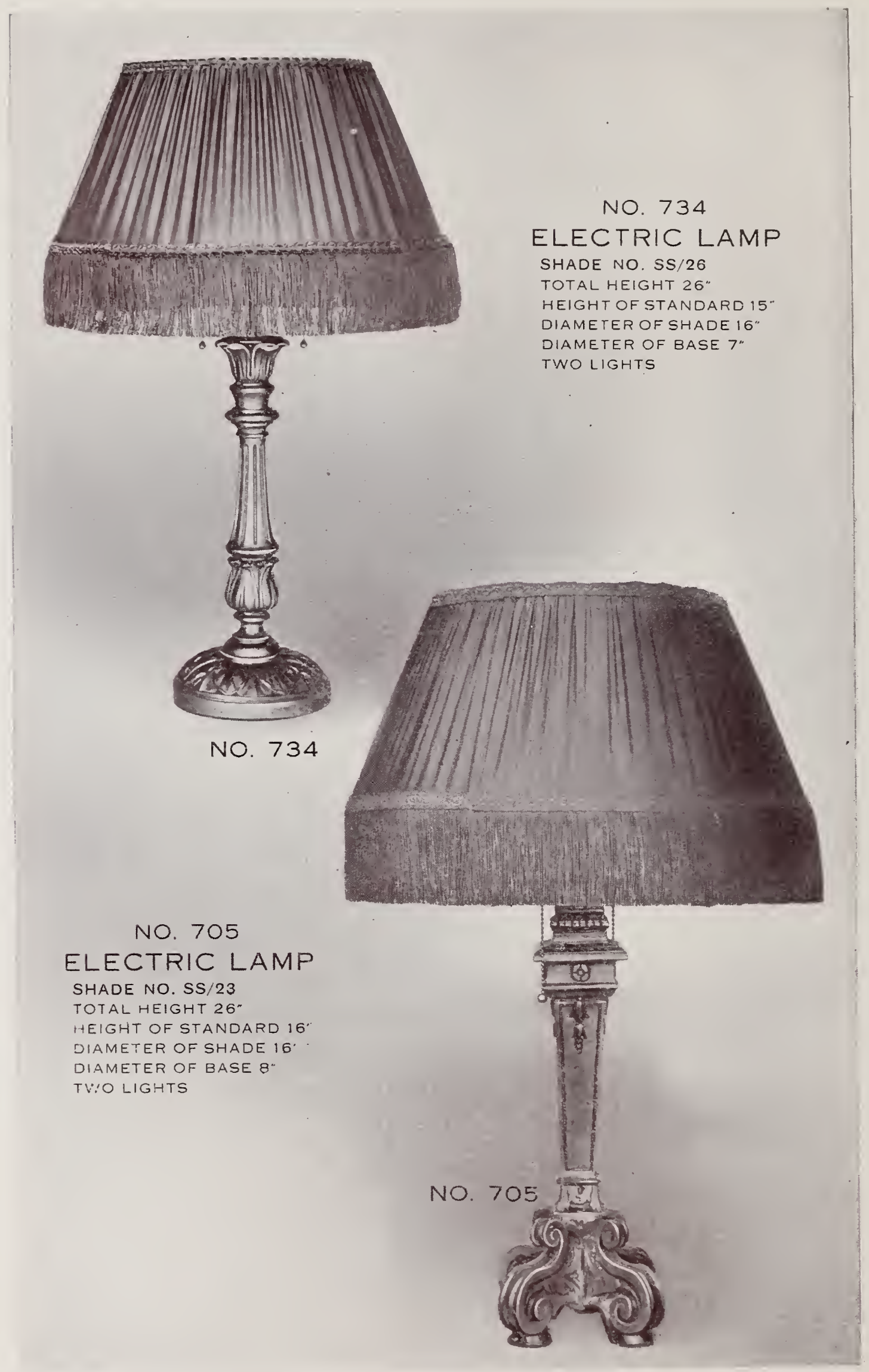

THE NATIONAL METALIZING COMPANY
B R O N Z E

ELECTRIC LAMP

SHADE NO. SS/26

HEIGHT OF STANDARD 15

DIAMETER OF SHADE 16"

DIAMETER OF BASE 7

WO LIGHTS 


\section{A R M O R}

NO. 740

ELECTRIC LAMP SHADE NO. SS/22 TOTAL HEIGHT 24" HEIGHT OF STANDARD $14^{*}$ DIAMETER OF SHADE $18^{\prime \prime}$ DIAMETER OF BASE $7 \%^{*}$ TWO LIGHTS
Price with

Shade $\$ 23.00$

Price without Shade $\$ 14.00$

Price with

Shade $\$ 21.00$

Price without Shade $\$ 12.00$

\section{THE NATIONAL METALIZING COMPANY}


A R M O R

Price with

Shade $\$ 23.00$

Price without Shade $\$ 14.00$

Price with

Shade $\$ 24.00$

Price without Shade $\$ 14.00$

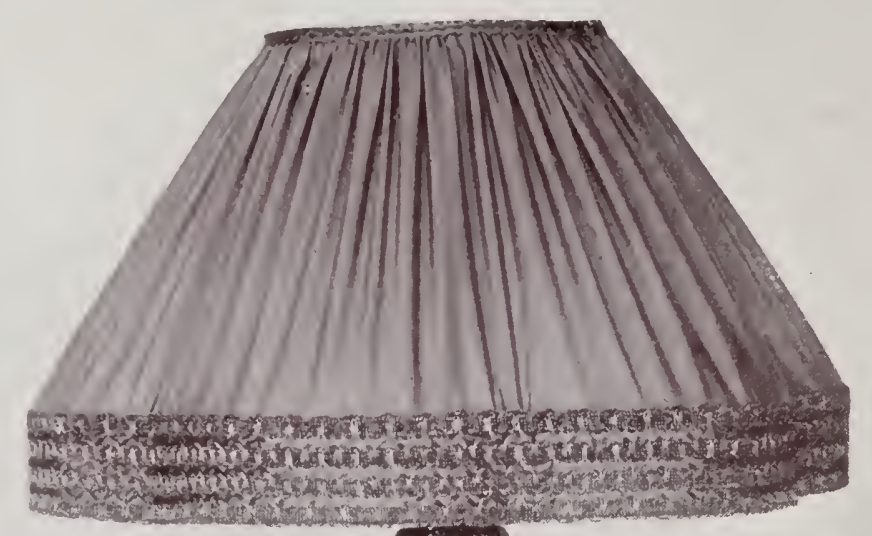

NO. 741

ELECTRIC LAMP SHADE NO. SS $/ 22$

TOTAL HEIGHT $24^{\circ}$

HEIGHT OF STANDARD 14

DIAMETER OF SHADE 16

DIAMETER OF BASE 7!:

TWO LIGHTS

NO. 743

ELECTRIC LAMP

SHADE NO. SS/23

TOTAL HEIGHT 25"

HEIGHT OF STANDARD 14"

DIAMETER OF SHADE 16"

DIAMETER OF BASE 71/2"

TWO LIGHTS
NO. 743

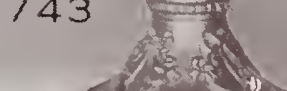




\section{A R M O R}

\section{B R O N Z E}

NO. 751

ELECTRIC LAMP

SHADE NO. SS $/ 23$

TOTAL HEIGHT 25"

HEIGHT OF STANDARD 14"

DIAMETER OF SHADE $16^{\prime \prime}$

DIAMETER OF BASE 8"

TWO LIGHTS
NO. 753

ELECTRIC LAMP

SHADE NO. SS $/ 37$

TOTAL HEIGHT $23^{1 / 2} \mathrm{z}^{\prime \prime}$

HEIGHT OF STANDARD $14^{\circ}$

DIAMETER OF SHADE $18^{\prime \prime}$

DIAMETER OF BASE 7"

TWO LIGHTS
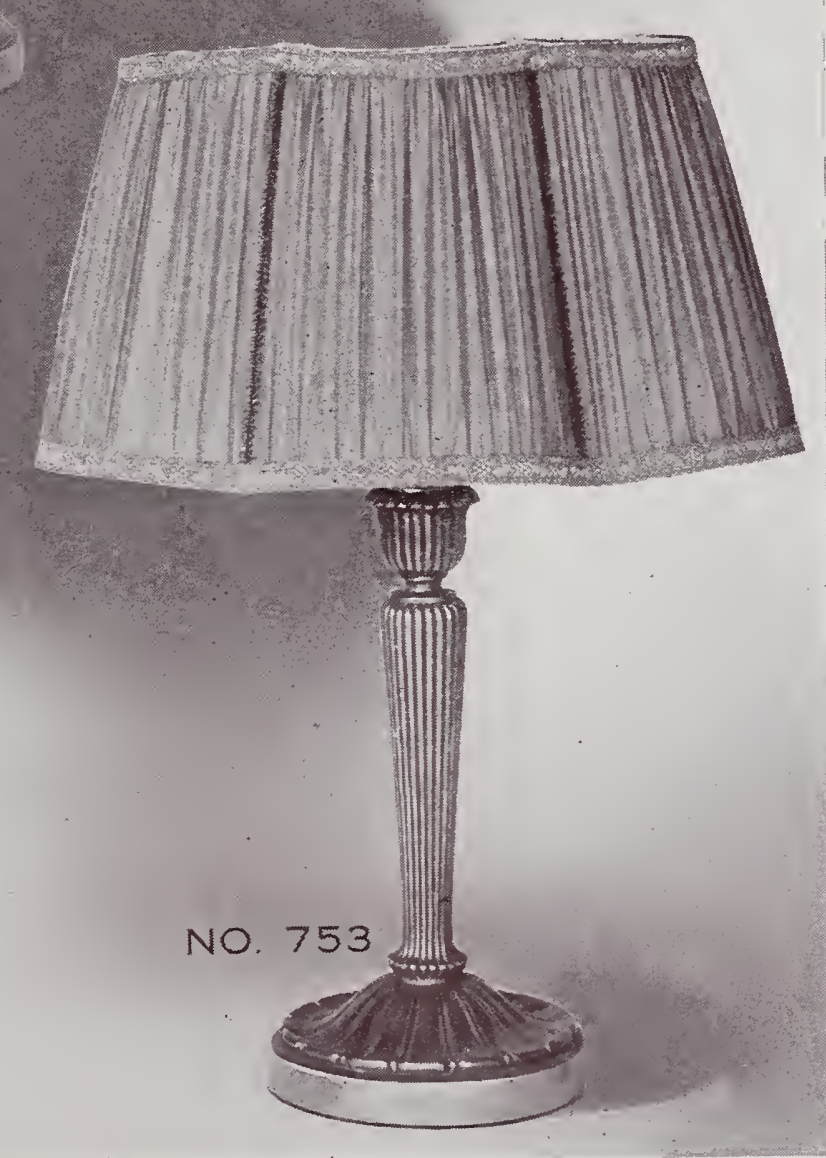

Price with

Shade $\$ 23.00$

Price without Shade $\$ 13.00$

Price with

Shade $\$ 21.00$

Price without Shade $\$ 12.00$ 
A R M O R

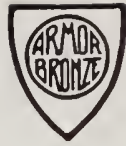

B R O N Z E

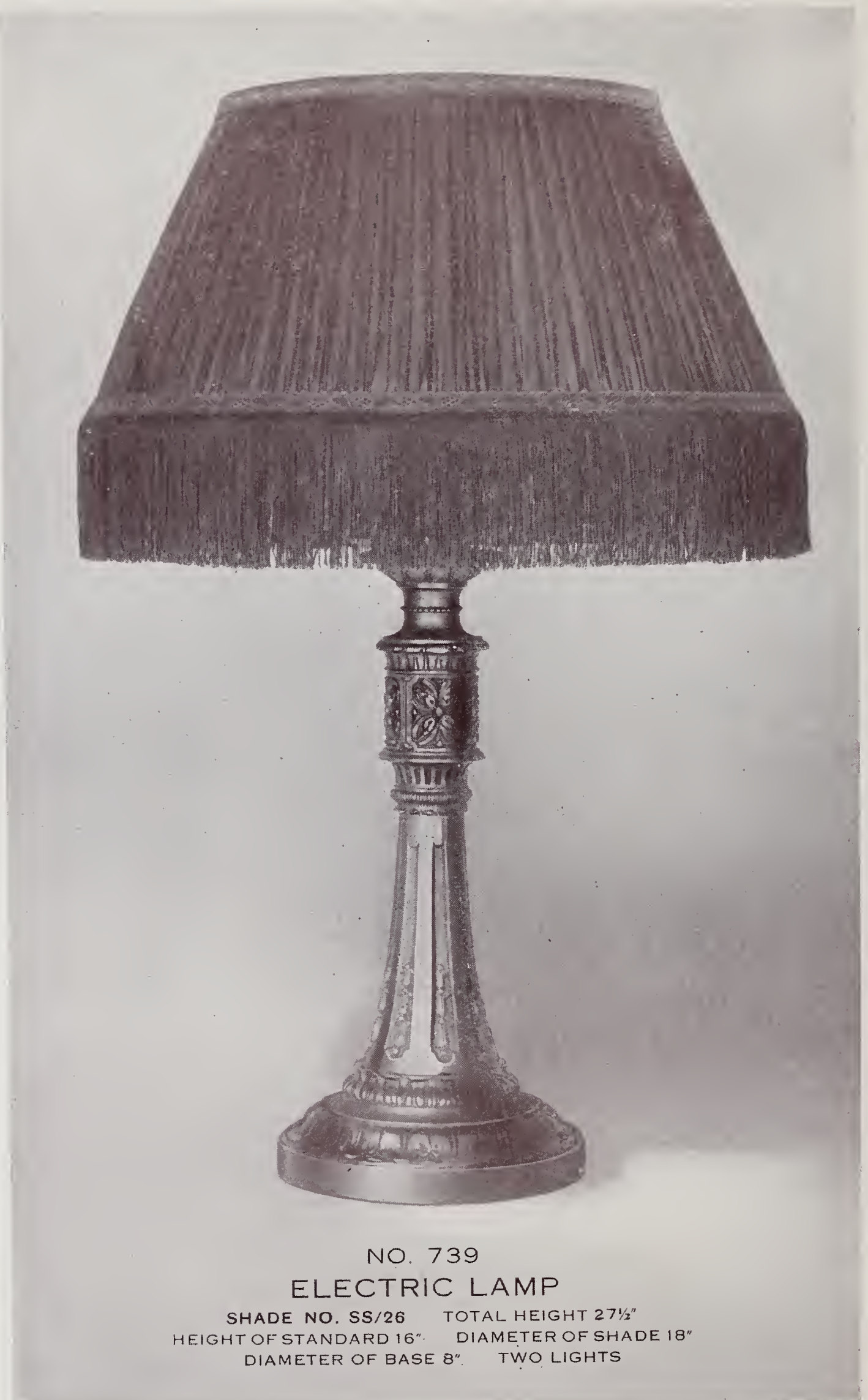

THE NATIONAL METALIZING COMPANY

Page Fifly-eight
P

Price with

Shade $\$ 34.00$

Price without Shade $\$ 20.00$ 


\section{A R M O R}

\section{B R O N Z E}

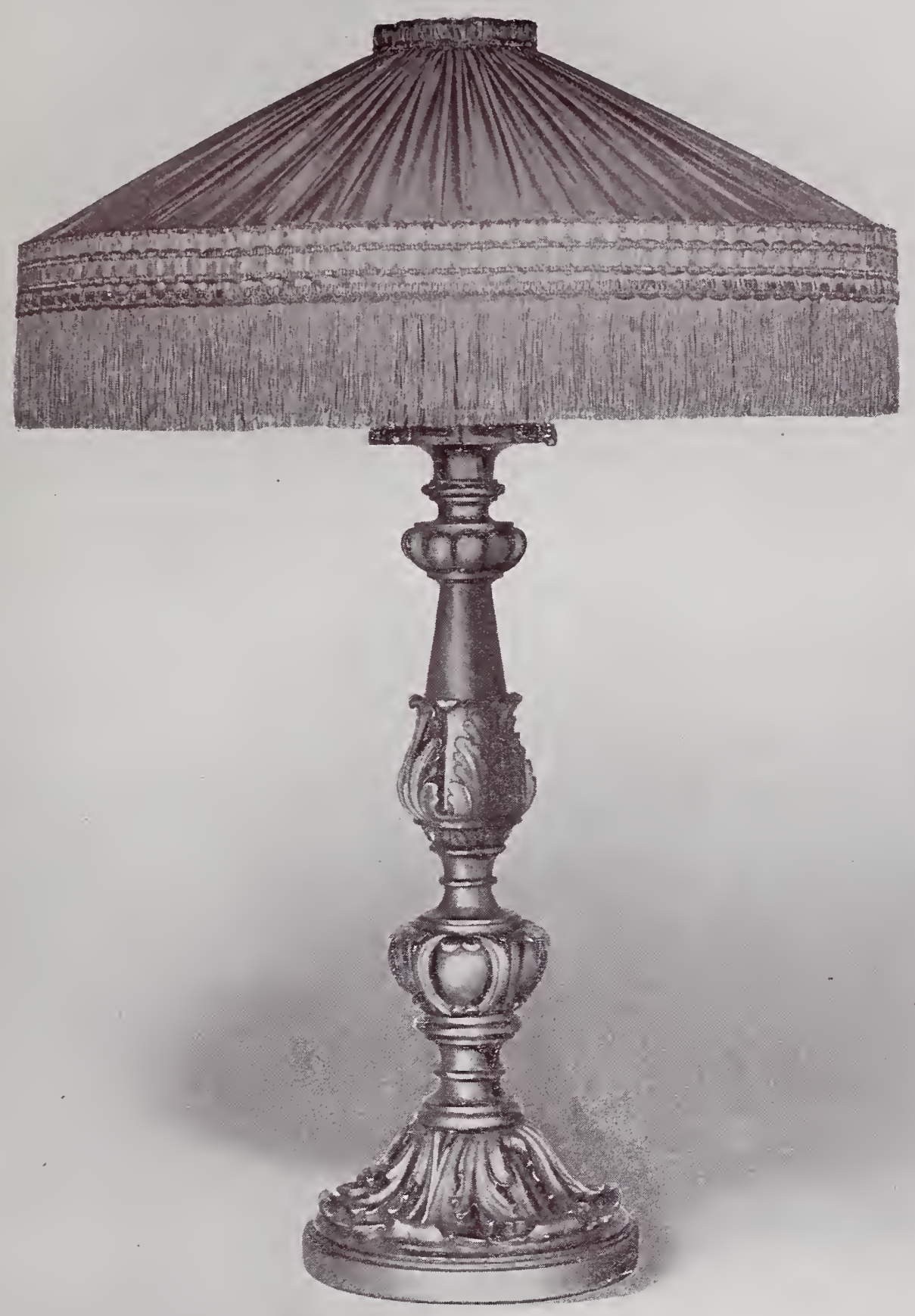

Price with

Shade $\$ 54.00$

Price without

Shade $\$ 30.00$

Price of

Lamp only in Polychrome

Finish, $\$ 35.00$

NO. 719

ELECTRIC LAMP

SHADE NO. SS/28 TOTAL HEIGHT 35.

HEIGHT OF STANDARD 24. DIAMETER OF SHADE $24^{\circ}$

DIAMETER OF BASE. 10" THREE LIGHTS 


\section{A R M O R}

Price with

Shade $\$ 23.00$

Price without Shade $\$ 13.00$

Price with

Shade $\$ 21.00$

Price without Shade $\$ 12.00$

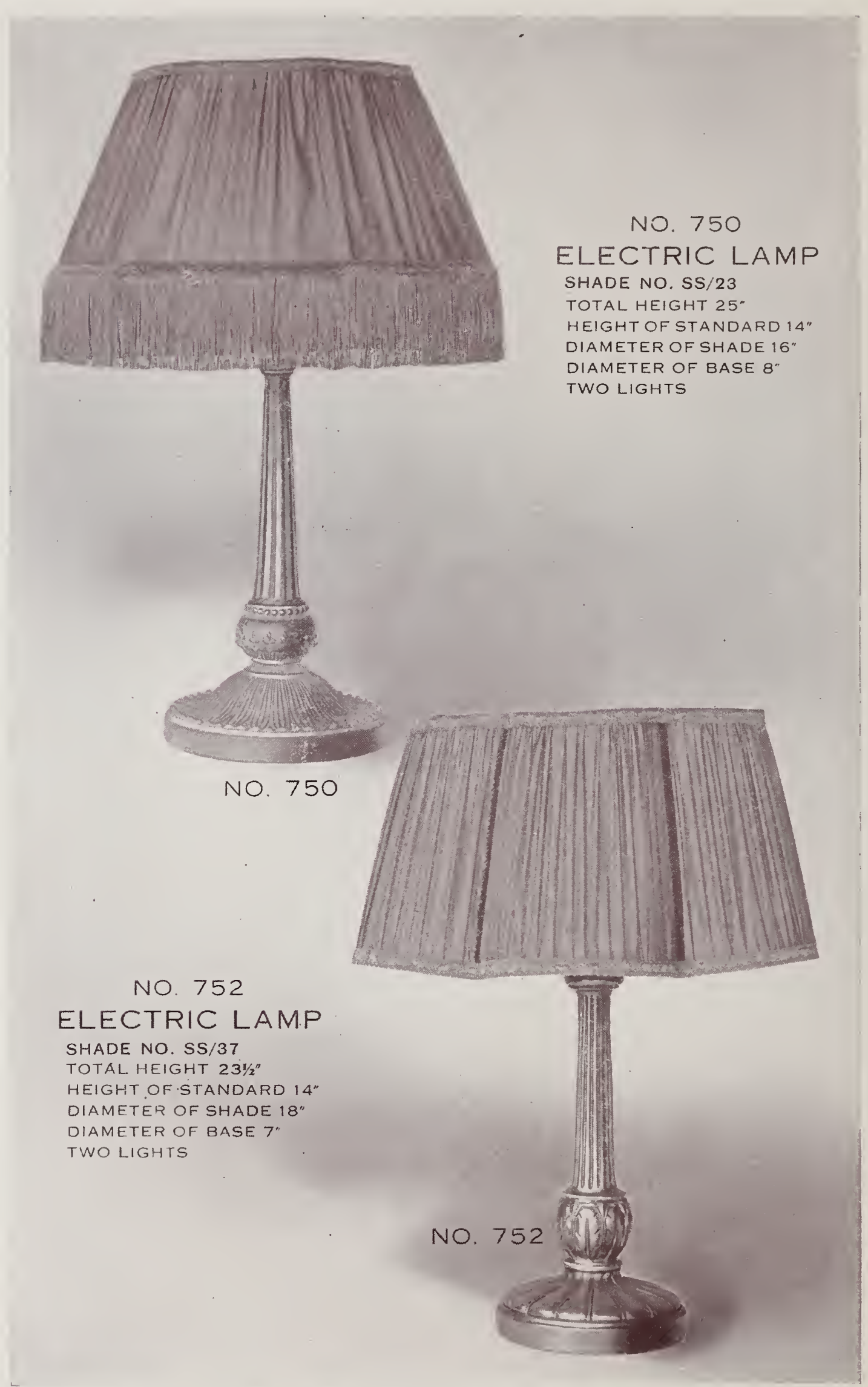


A R M O R

B R O N Z E

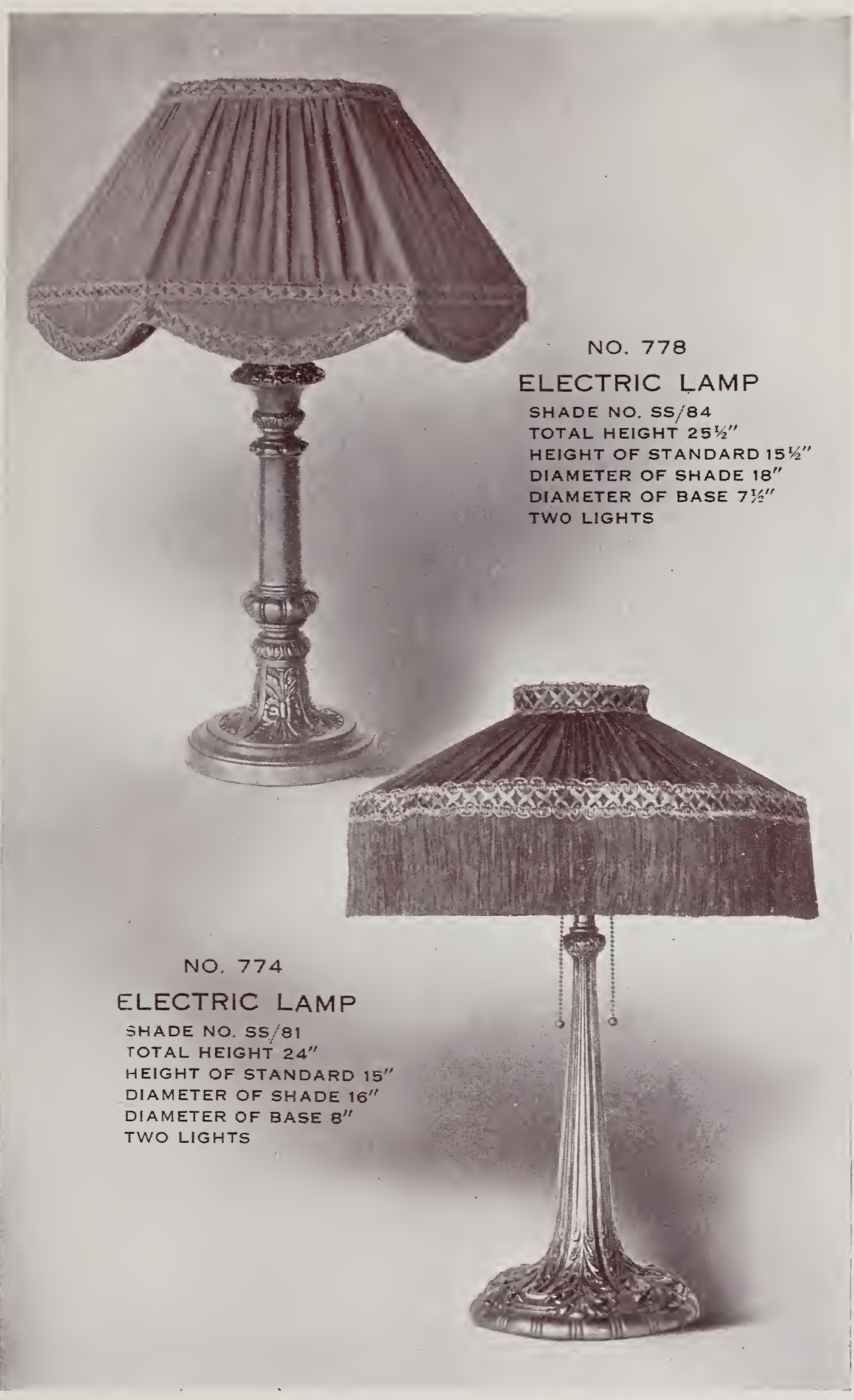

Price with

Shade $\$ 25.00$

Price without Shade $\$ 14.00$

Price with

Shade $\$ 25.00$

Price without Sharle $\$ 13.00$ 


\section{A R M O R}

Price with

Shade $\$ 50.00$

Price without Shade $\$ 24.00$

Price of Lamp only in Polychrome and Sgraffito Finish, $\$ 30.00$

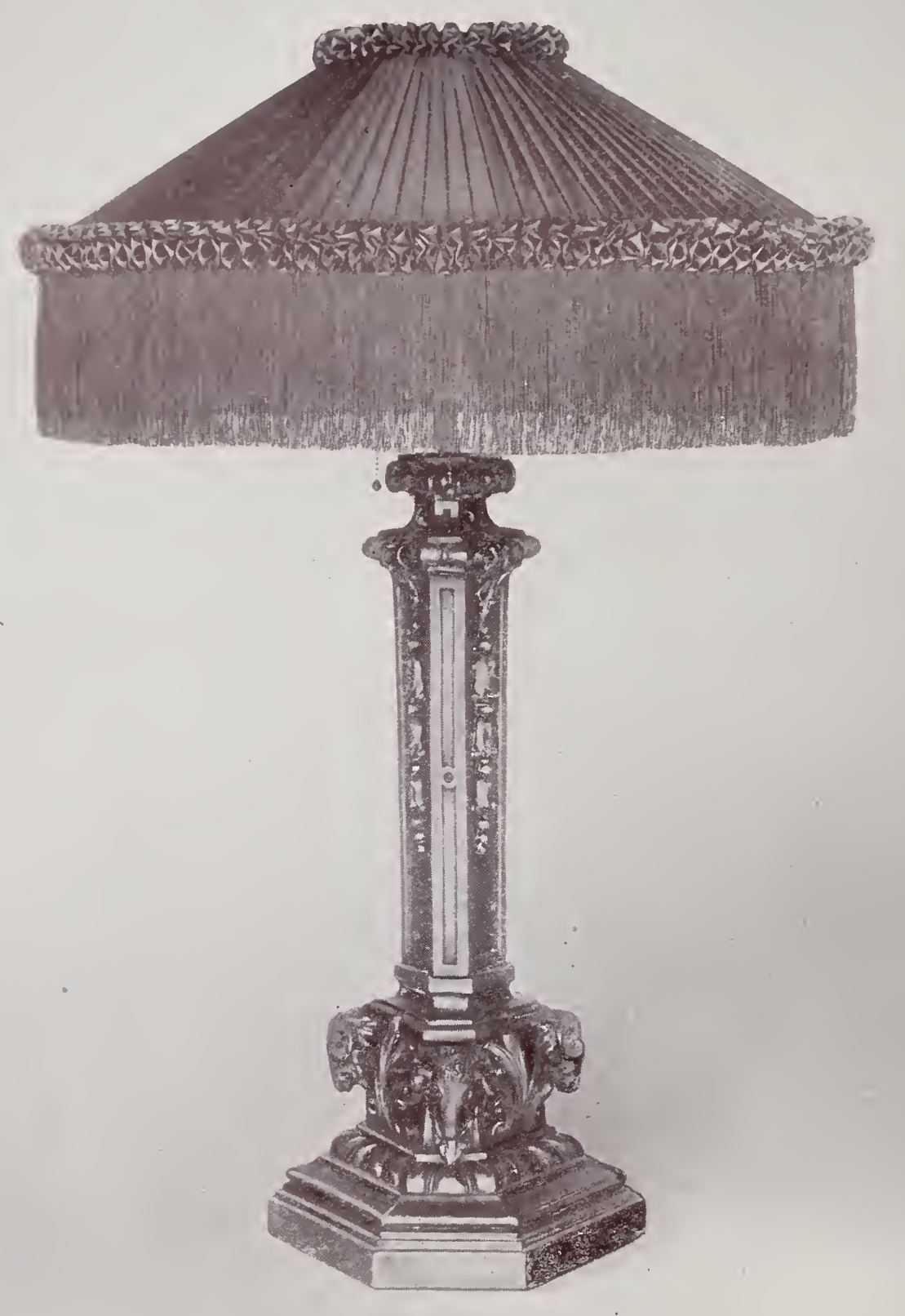

NO. 730

ELECTRIC LAMP

SHADE NO SS/30 TOTAL HEIGHT $33^{\circ}$

HEIGHT OF STANDARD 22" DIAMETER OF SHADE 22

DIAMETER OF BASE 11" THREE LIGHTS 


\section{A R M O R}

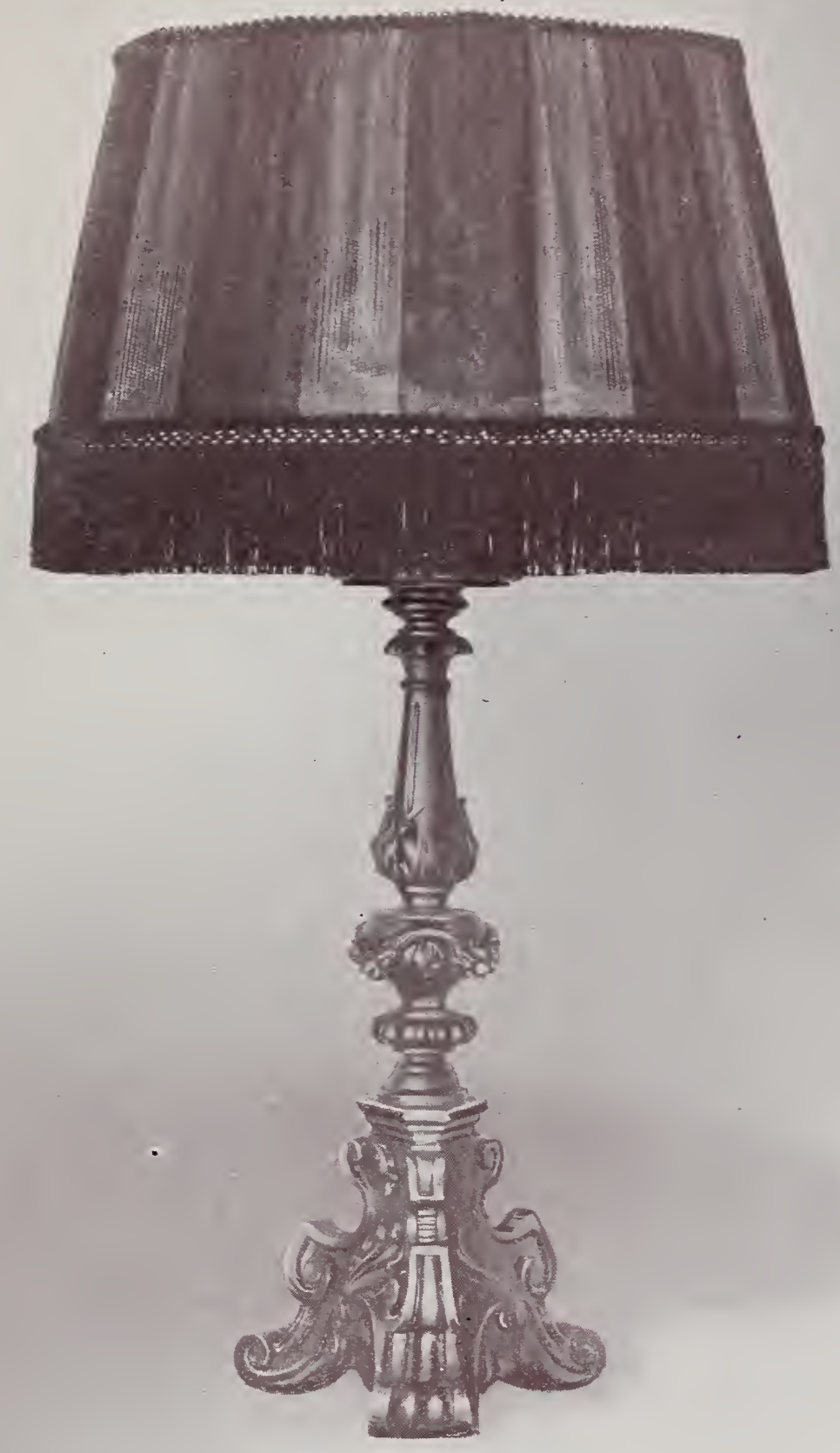

Price with

Shade $\$ 44.00$

Price without Shade $\$ 24.00$

$$
\text { NO. } 718
$$

ELECTRIC LAMP

SHADE NO. SS/27 TOTAL HEIGHT 351/2"

HEIGHT OF STANDARD 22' DIAMETER OF SHADE 20"

DIAMETER OF BASE 10" THREE LIGHTS

\section{THE NATIONAL METALIZING COMPANY}


A R M O R

B R O N Z E

Price $\$ 100.00$

Price with

Silk Shades same as No. 760 $\$ 110.00$

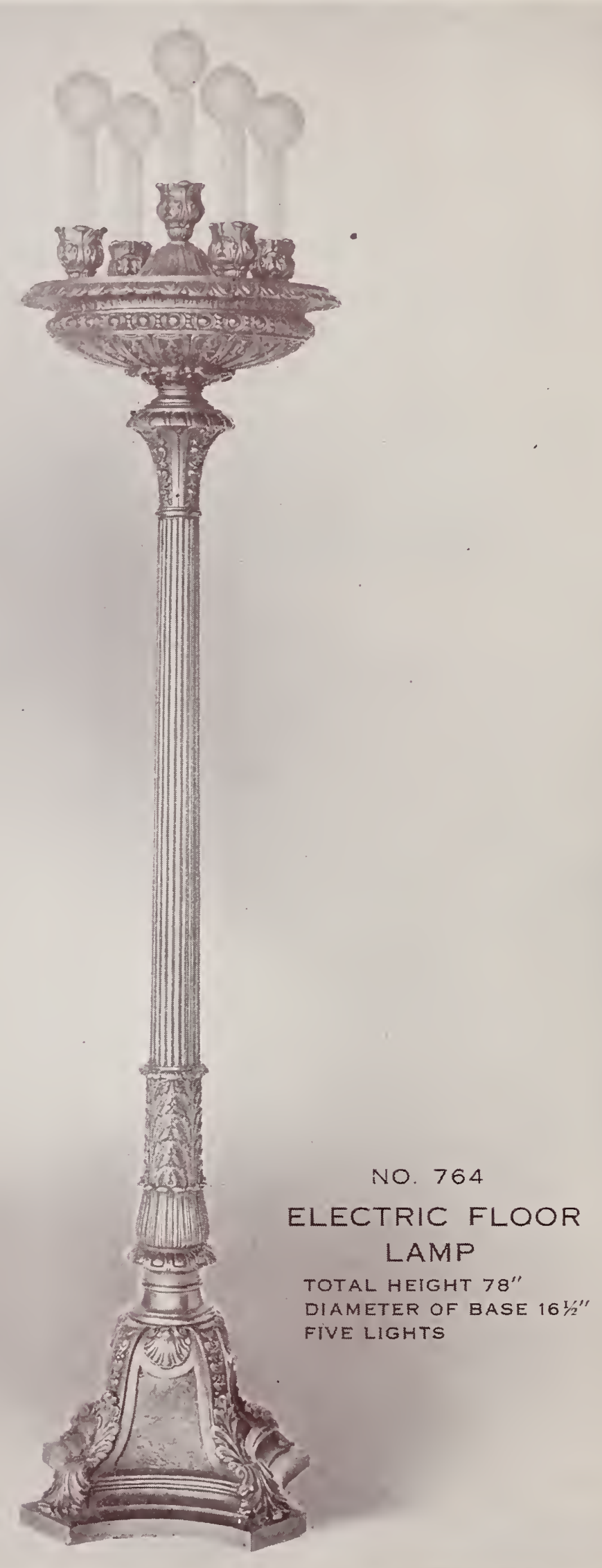

THE NATIONAL METALIZING COMPANY 


\section{A R M O R}

B R O N Z E

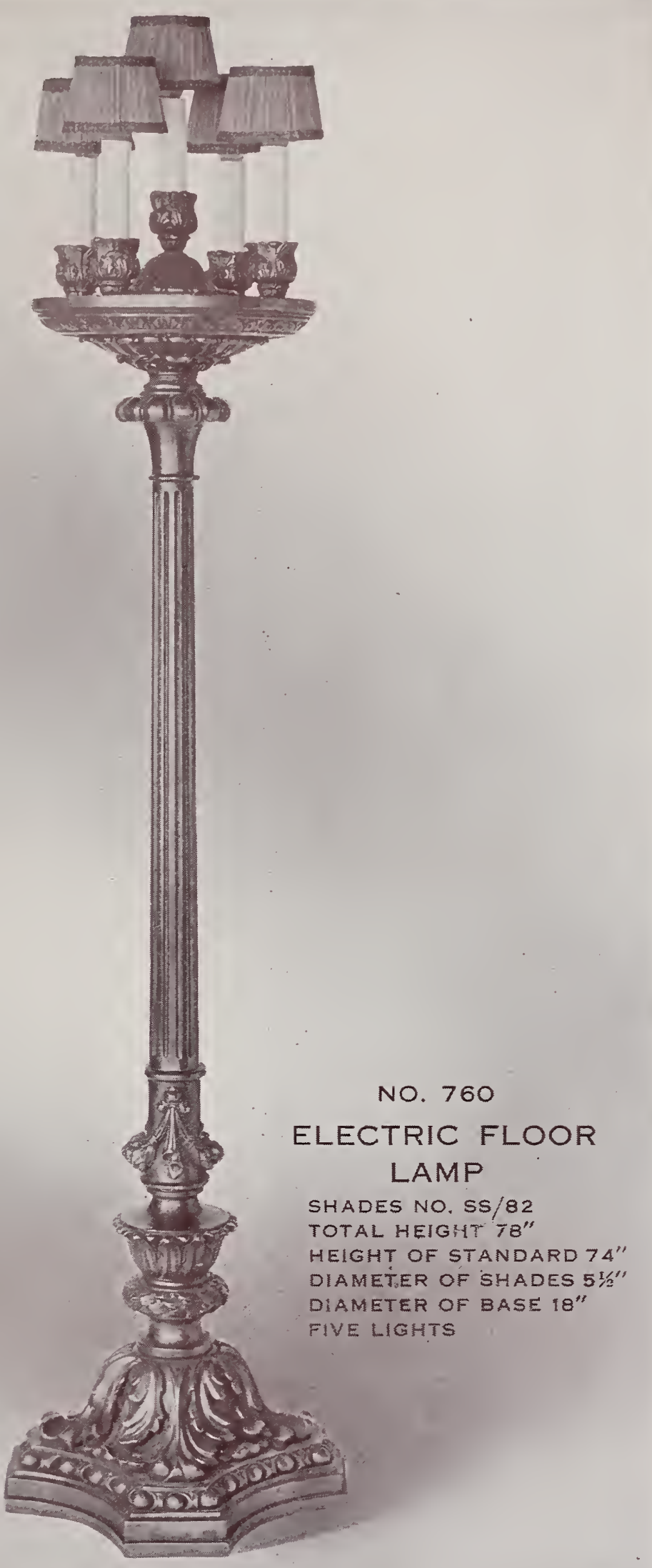

Price $\$ 110.00$

Price withcut

Silk Shades

same as No. 764 $\$ 100.00$ 


\section{A R M O R}

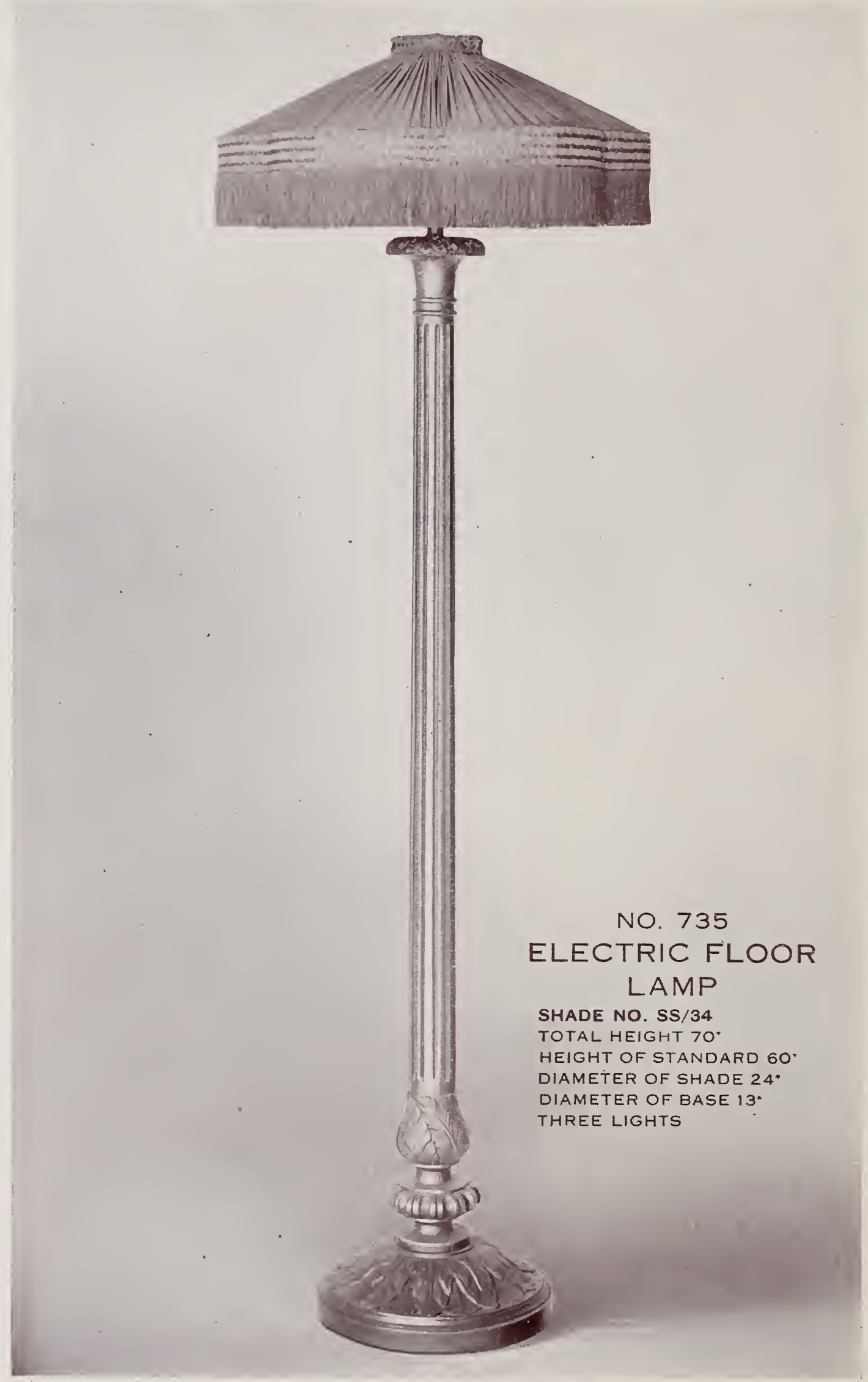

Price with

Shade $\$ 64.00$

\section{Price without}

Shade $\$ 40.00$

Price of

Lamp only in Polychrome Finish, \$50.00 


\section{A R M O R}

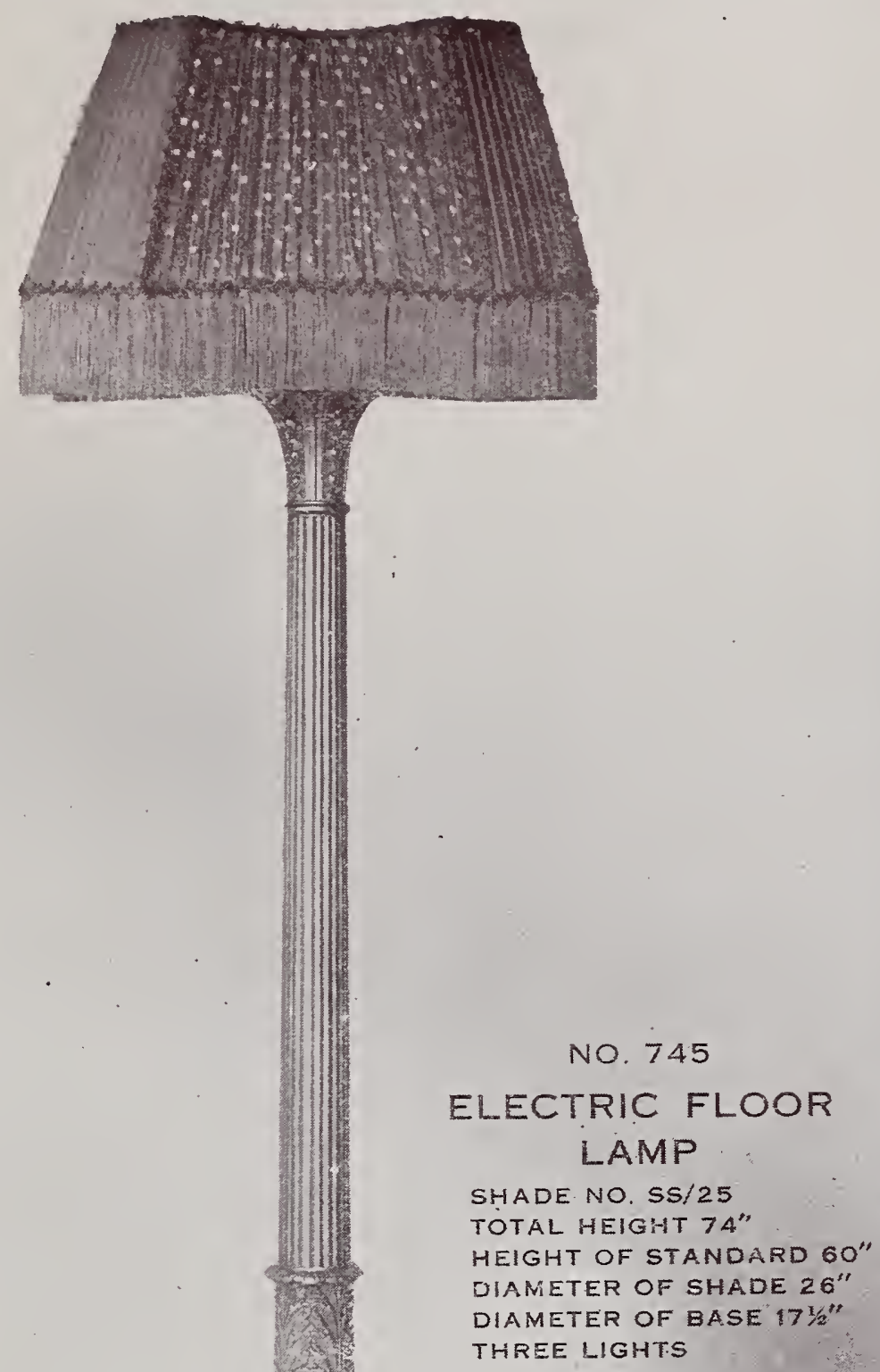

Price with

Shade $\$ 78.00$

Price without Shade $\$ 52.00$

Price of

Lamp only

in Polychrome

Finish, $\$ 65.00$ 
Price with

Shade $\$ 74.00$

Price without Shade $\$ 50.00$

\section{Price of}

Lamp only

in Polychrome

Finish. $\$ 64.00$

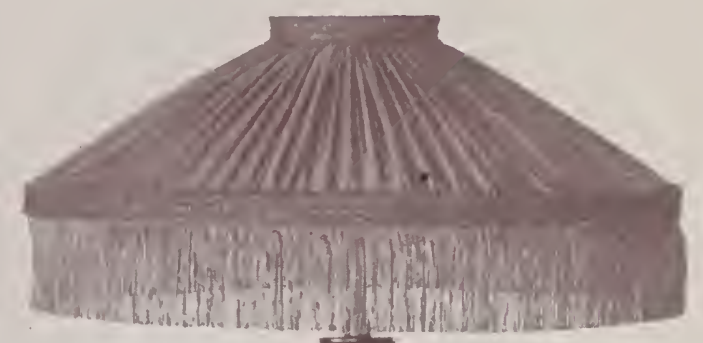

NO. 765

ELECTRIC FLOOR

LAMP

SHADE NO. $S S / 28$

TOTAL HEIGHT $72^{\prime \prime}$

HEIGHT OF STANDARD $60^{\circ}$

DIAMETER OF SHADE $24^{\prime \prime}$

DIAMETER OF BASE $16^{\prime \prime}$

THREE LIGHTS 


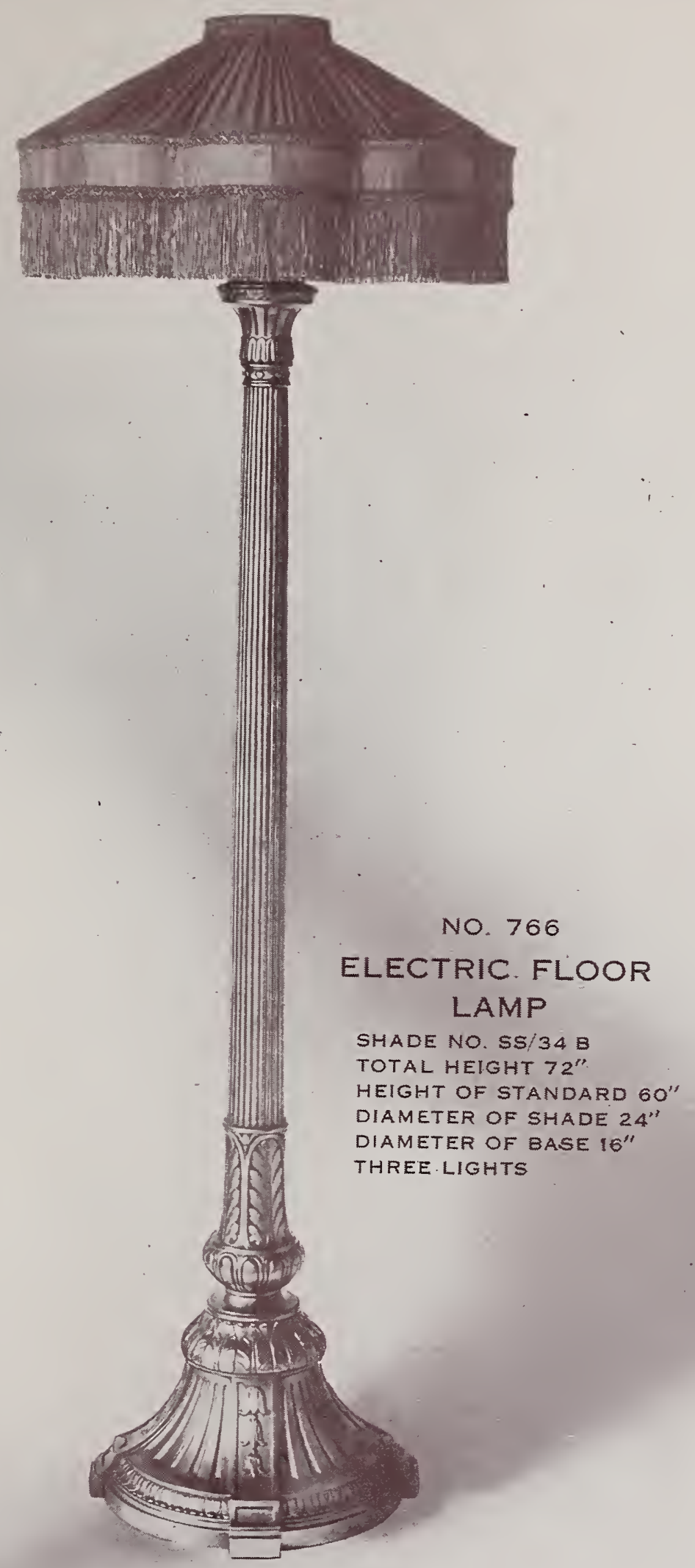

Price with

Shade $\$ 80.00$

Price without Shade $\$ 56.00$

Price of

Lamp only

in Polychrome

Finish, $\$ 70.00$ 


\section{A R M O R}

\section{B R O N Z E}

Price with

Shade $\$ 76.00$

Price without

Shade $\$ 52.00$

Price of

Lamp only

in Polychrome

Finish, $\$ 64.00$

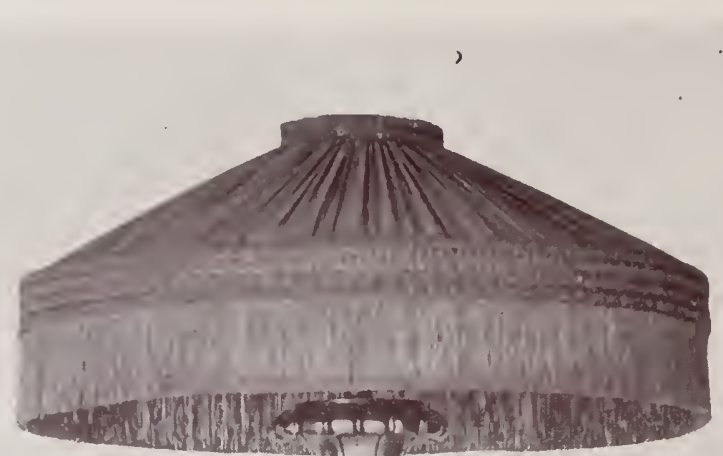

NO. 737

ELECTRIC FLOOR LAMP

SHADE NO. SS/28

TOTAL HEIGHT $72^{\prime \prime}$

HEIGHT OF STANDARD $60^{\circ}$

DIAMETER OF SHADE $24^{\circ}$

DIAMETER OF BASE 15'

THREE LIGHTS 


\section{A R M O R}

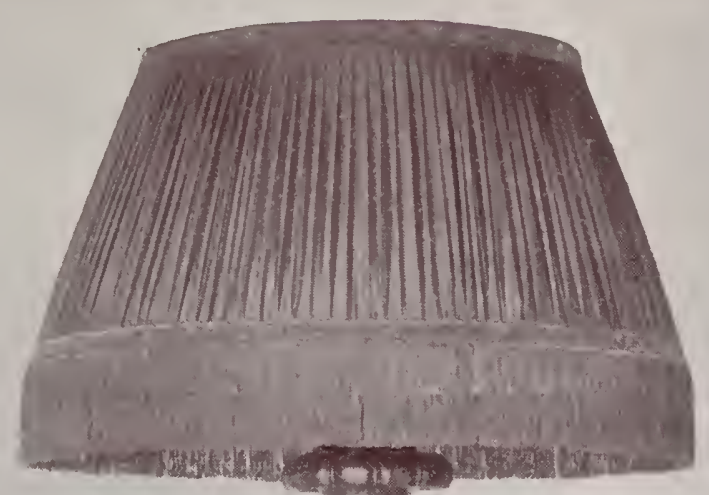

NO. 738

ELECTRIC FLOOR

LAMP

SHADE NO. SS $/ 26$

TOTAL HEIGHT $75^{\circ}$

HEIGHT OF STANDARD 60"

DIAMETER OF SHADE 24

DIAMETER OF BASE 18 "

THREE LIGHTS

Price with

Shade $\$ 84.00$

Price without

Shade $\$ 60.00$

Price of

Lamp only

in Polychrome

Finish, $\$ 75.00$ 


\section{A R M O R}

Price with

Shade $\$ 76.00$

Price without Shade $\$ 60.00$

Price of

Lamp only

in Polychrome

Finish, $\$ 75.00$

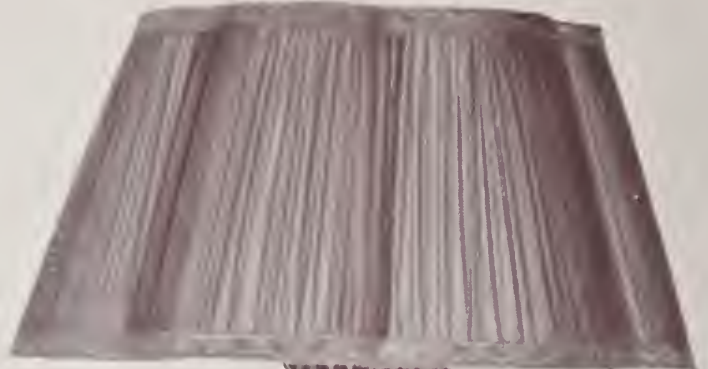

NO. 724

ELECTRIC FLOOR

LAMP

SHADE NO. SS/37

TOTAL HEIGH' $72^{\prime \prime}$

HEIGHT OF STANDARD $60^{\circ}$

DIAMETER OF SHADE $24^{\prime \prime}$

DIAMETER OF BASE $16^{\prime \prime}$

THREE LIGHTS 
A R M O R

B R O N Z E

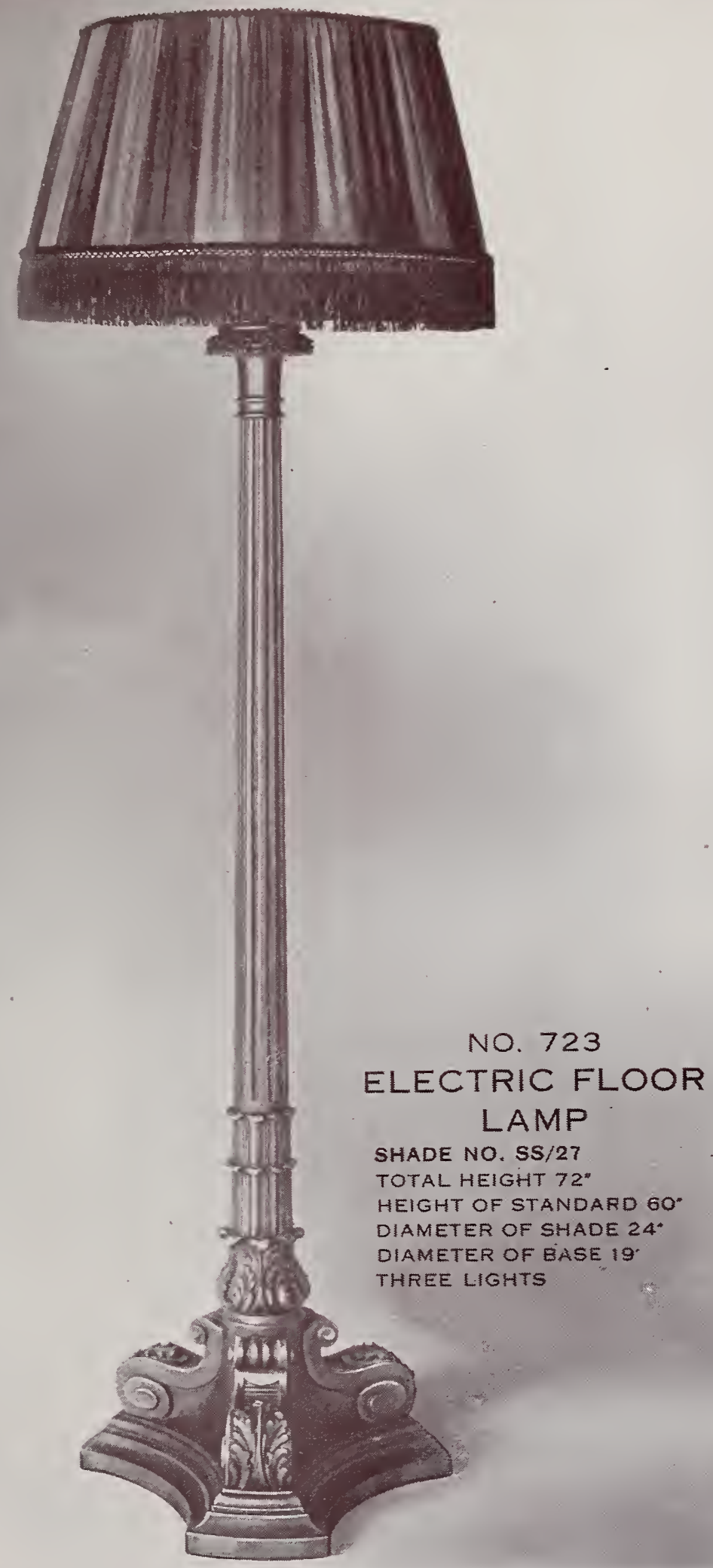

Price with

Shade $\$ 84.00$

Price without

Shade $\$ 60.00$

Price of

Lamp only in Polychrome

Finish, $\$ 75.00$ 
Price with

Shade $\$ 84.00$

Price without Shade $\$ 60.00$

Price of

Lamp only

in Polychrome

Finish, $\$ 75.00$
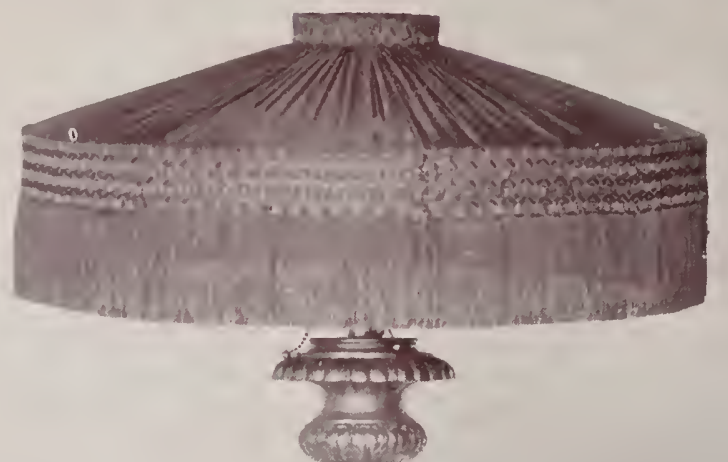

NO. 744 ELECTRIC FLOOR LAMP SHADE NO. $\$ S / 28$ TOTAL HEIGHT 72 HEIGHT OF STANDARD $60^{\circ}$ DIAMETER OF SHADE $24^{*}$ DIAMETER OF BASE $161 / 4^{\prime \prime}$ THREE LIGHTS 


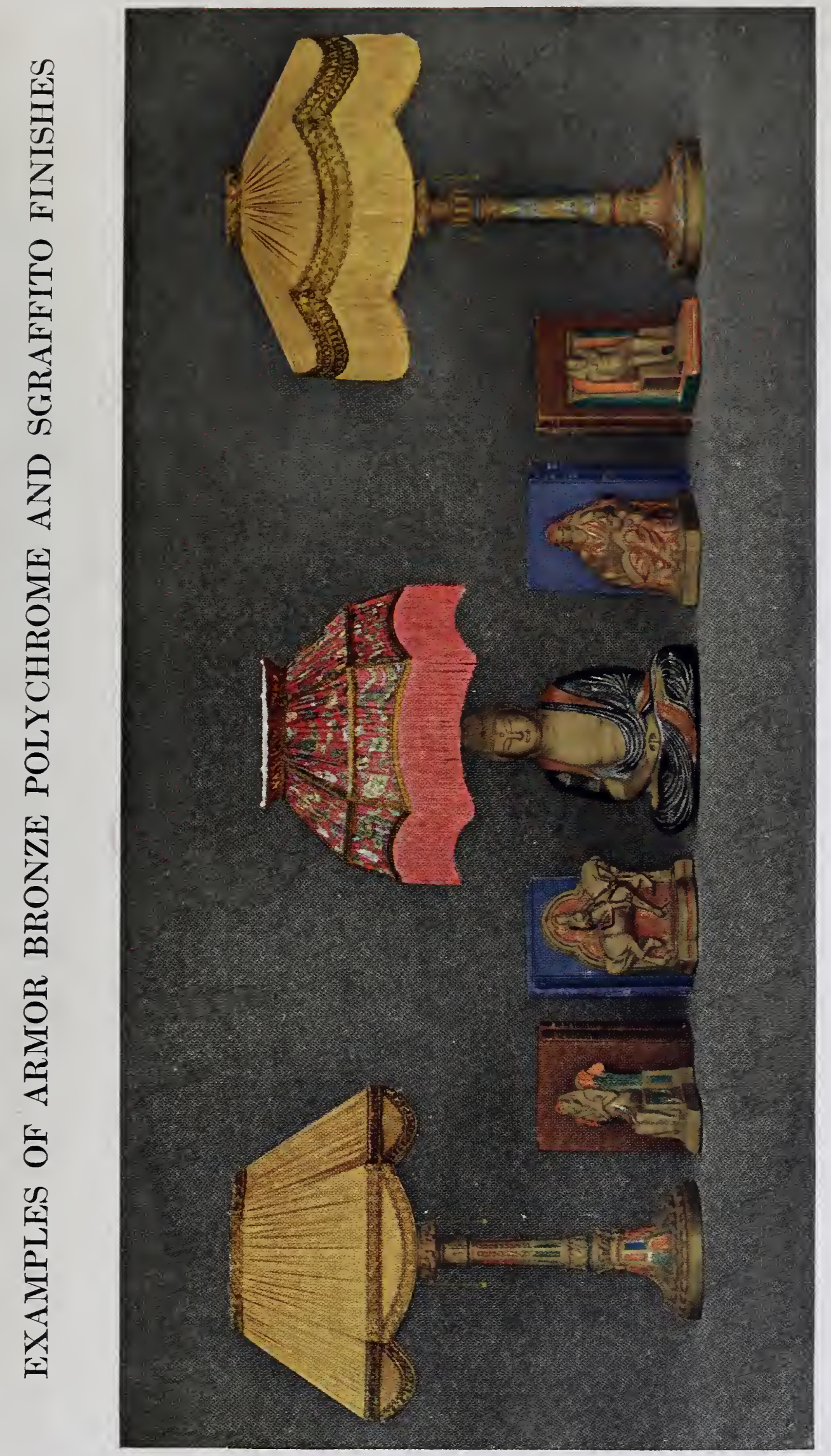

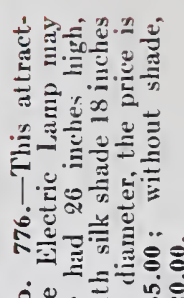



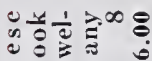

管

T:

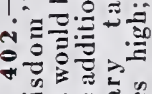

*

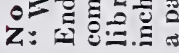

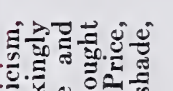

范

के के है.

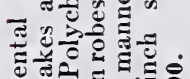

政

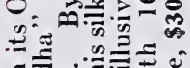

.

品

政字.

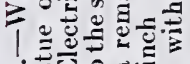

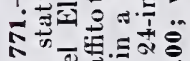

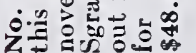

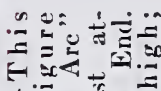

10

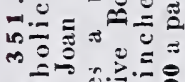

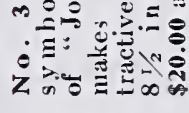

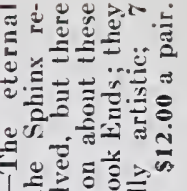

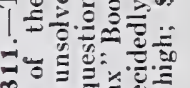

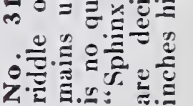

$\stackrel{2}{2}$

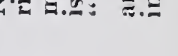

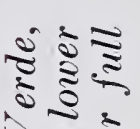

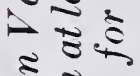

.

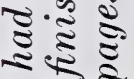

$\therefore \div$

을.

퐁

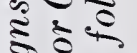

के

ह ะ

ริะก

ज

ठำ

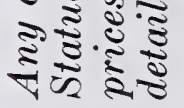

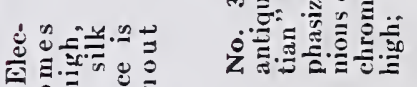

政

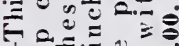

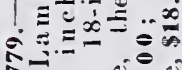

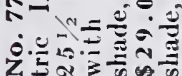

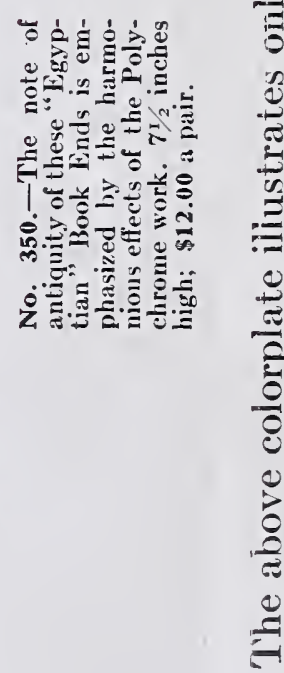

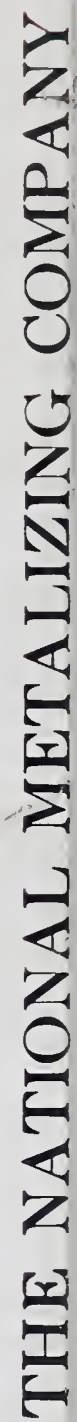

0
0
0
0
0
0
0
0
0
0
0
0 


\section{(1)

